\title{
AVALIAÇÃO DA CERTIFICAÇÃO ISO 14001: ESTUDO DE CASO NO SETOR AUTOMOTIVO
}

\section{Tatiana Tucunduva Philippi}

Dissertação apresentada ao Departamento de Saúde Ambiental da Faculdade de Saúde Pública da Universidade de São Paulo para obtenção do Título de Mestre em Saúde Pública.

Área de Concentração: Saúde Ambiental

Orientadora: Profa. Dra. Gilda Collet Bruna 


\section{AVALIAÇÃO DA CERTIFICAÇÃO ISO 14001: ESTUDO DE CASO NO SETOR AUTOMOTIVO}

\section{Tatiana Tucunduva Philippi}

Dissertação apresentada ao Departamento de Saúde Ambiental da Faculdade de Saúde Pública da Universidade de São Paulo para obtenção do Título de Mestre em Saúde Pública.

Área de Concentração: Saúde Ambiental

Orientadora: Profa. Dra. Gilda Collet Bruna 
Autorizo, exclusivamente para fins acadêmicos e científicos, a reprodução total ou parcial desta tese, por processos fotocopiadores.

Assinatura:

Data: 


\section{AGRADECIMENTOS}

Aos meus pais, Arlindo e Sonia, por me proporcionarem o melhor que a vida pode oferecer: muito amor, carinho, companheirismo, apoio, incentivo, estímulo.

Ao meu irmão Caio, por sua alegria de viver e capacidade de me fazer sorrir a qualquer momento.

À minha adorada avó Nádia, pela pessoa maravilhosa que é, pelo seu carinho e pelas incontáveis preces para me proteger e ajudar a atingir meus objetivos.

Ao Gustavo Pasquale Cortese, por ser tão especial.....por todo seu amor, palavras de incentivo, paciência nas horas de desespero com o computador, por estar sempre presente.

À minha querida orientadora Gilda Collet Bruna, por toda a dedicação, competência e confiança em mim depositada.

Ao Prof. Dr. Carlos Celso do Amaral e Silva, membro da banca examinadora, pela prontidão com que se dispôs a me ajudar, por suas sugestões e sua alegria de sempre.

Ao Prof. Dr. Alaôr Caffé Alves, membro da banca examinadora, pela dedicação ao direito ambiental brasileiro, por suas sugestões e pelo carinho com que me recebeu.

Ao querido amigo Antônio Fernando Pinheiro Pedro, por sua amizade, por despertar em mim o interesse pelo direito ambiental, pelo carinho de sempre.

Aos meus amigos Luciana e Luís, por cuidarem de mim e me darem o equilíbrio necessário para finalizar este trabalho.

À querida amiga Patrícia Tischler Rodrigues da Cunha, pela disponibilidade e apoio na realização das entrevistas. 
Aos amigos que colaboraram na realização do pré-teste do questionário: Profa. Dra. Maria Cecília Pelicioni, Alexandre Aguiar, Cíntia, Tadeu e Giuliano.

Ao Fernão Dias de Lima, pela atenção e orientação nos aspectos estatísticos do trabalho.

À bibliotecária Maria do Carmo Avamilano Alvarez, pela revisão da bibliografia do trabalho.

Ao Núcleo de Informações em Saúde Ambiental da Universidade de São Paulo NISAM/USP, pelo apoio prestado para a consecução deste trabalho: Prof. Dr. Arlindo Philippi Junior, Cíntia, Mary, Sérgio Tucunduva, Júnior, Daniella, Tami.

Aos diretores e colaboradores da empresa objeto deste estudo, por terem me recebido tão bem e proporcionado todo o apoio e acesso às informações necessárias à realização do presente trabalho. 


\section{RESUMO}

Philippi TT. Avaliação da certificação ISO 14001: estudo de caso no setor automotivo. São Paulo; 2003. [Dissertação de Mestrado - Faculdade de Saúde Pública da Universidade de São Paulo]

Novas concepções de gestão empresarial têm surgido, baseadas no princípio que estabelece uma política de qualidade ambiental, incorporando à atividade industrial as bases da promoção da sustentabilidade do desenvolvimento. Objetivos: Avaliar o processo da certificação ISO $14001 \mathrm{em}$ uma empresa do setor automotivo e o grau de conhecimento e envolvimento dos entrevistados, com relação ao processo de implantação, implementação, certificação e pós-certificação. Metodologia: um estudo de caso, com abordagem metodológica descritiva, quantitativa e qualitativa, de uma multinacional do setor automotivo, localizada no Município de São Bernardo do Campo, São Paulo. Alguns dos critérios para o estudo foram: certificação em conformidade com a ISO 14001; SGA implementado e em funcionamento; liderança na área de meio ambiente em nível nacional e internacional; com participação junto às comunidades do entorno, no exercício da cidadania corporativa e que concordasse e permitisse a realização do estudo, com acesso às informações necessárias. Os dados foram observacionais e obtidos por meio de entrevistas com os indivíduos envolvidos. A análise dos dados foi feita utilizando o Método de Análise de Conteúdo de BARDIN (1995). Resultados: A empresa possui mais de 9.000 funcionários, 21 setores envolvidos no processo de implementação do SGA. A maioria dos entrevistados possui curso superior completo e destes, $68,2 \%$ em engenharia. As principais motivações da empresa ao buscar a certificação foram, de acordo com $43,5 \%$ das respostas, a preocupação e o comprometimento com o meio ambiente e, para 34,8\% dos entrevistados, as exigências de mercado e o controle sobre os impactos causados ao ambiente. Após a certificação, ocorreram mudanças significativas dentro da empresa na opinião de $82,6 \%$ dos colaboradores. Com relação à minimização dos riscos de novas e futuras vulnerabilidades legais e à maior conscientização e percepção dos trabalhadores em relação à questão ambiental, $95,7 \%$ das respostas foram positivas. Sobre as dificuldades e conflitos encontrados durante o processo de certificação, 52,2\% apontaram a conscientização em todos os níveis como sendo a maior delas. Os funcionários do "chão de fábrica" $(47,5 \%)$ sabem dizer que a ISO é relacionada com o meio ambiente. Alguns dos principais benefícios obtidos, após 19 meses da certificação, são a responsabilidade ambiental, com 43,5\%, e a melhoria da imagem da empresa, com $21,7 \%$ das respostas. A certificação trouxe ganho para a empresa, para os funcionários, para a sociedade em geral e para o meio ambiente, tendo sido considerada a maior conquista de todas a conscientização ambiental adquirida, na opinião de 50,0\% dos entrevistados. Conclusões: O SGA, embora não seja a única solução para a resolução de todas as questões ambientais de uma organização, ele é uma ferramenta muito importante para o diagnóstico e gerenciamento destas questões.

Descritores: auditoria ambiental; gerenciamento ambiental; implementação de um SGA; certificação ambiental; ISO 14001. 


\begin{abstract}
Philippi TT. Evaluation of the ISO 14001 certification: case in an automotive

industry [Avaliação da certificação ISO 14001: estudo de caso no setor automotivo]. São Paulo; 2003. [Dissertação de Mestrado - Faculdade de Saúde Pública da Universidade de São Paulo]
\end{abstract}

New conceptions of environmental management arise all the time, based on the principles that establish an environmental quality policy, incorporating the basis of a sustainable development to the industrial activities. Objectives: To evaluate the certification process in an industry of the automotive sector and how involved the employees of the company are. Methods: ISO 14001 implementation case study, with a descriptive, qualitative and quantitative methodology, in a multinational company located in São Bernardo do Campo - São Paulo. Some criterions used to choose this company were: having an ISO 14001 certificate; an effective EMS; leadership in the environmental issues; social work with the local communities; and, most of all, that would allow this study to happen. Data were obtained through a survey technique, and a questionnaire as the main tool of the research. Data analysis was carried out through contents analysis methods (BARDIN 1995). Results: The company has more than 9.000 employees and 21 internal divisions involved with the implementation process. Most of the employees are engineer (68,2\%). The decision of going after the ISO 14001 certificate was based on the company's environmental commitment $(43,5 \%)$, and according to $34,8 \%$ of the answers, it was motivated by the attraction of new customers and markets (or at least retain access to customers and markets with EMS requirements) and to prevent pollution and conserve resources. After the certification, $82,6 \%$ of the employees said that some significant changes were made inside the company, such as: enhance compliance and reduce/mitigate risks $(95,7 \%)$; enhance awareness and involvement of the employee team (95,7\%). You should note, however, that developing and implementing an EMS may have some difficulties. $52,2 \%$ pointed out that the environmental education is the most difficult thing to achieve. The answers obtained with the working class show that they do know $(47,5 \%)$ the meaning of ISO 14001 . Once the system is implemented, it is possible to realize the most relevant benefits obtained through the certification, which are the environmental liability $(43,5 \%)$; and enhance image with public, regulators, lenders, investors (21,7\%). The ISO 14001 certification brings improvements in overall environmental performance and compliance. Conclusions: Although the EMS is not the solution for all environmental issues, it can result in both business and environmental benefits. The standard establishes a management framework by which an organizations' impacts on the environment can be systematically identified and reduced.

Descriptors: environmental auditing; environmental management; environmental management system; implementation of an EMS; environmental certification; ISO 14001 . 


\section{ÍNDICE}

1. INTRODUÇÃ̃O

1.1 Introdução à problemática ambiental.................................................... 1

1.2 Auditoria ambiental: conceitos............................................................... 6

1.3 Tipos de auditoria ambiental...................................................... 10

1.4 Legislação ambiental aplicável........................................................... 13

1.4.1 Evolução da legislação ambiental no Brasil......................... 14

1.4.2 Princípios relevantes do direito ambiental........................... 23

1.5 Planejamento de auditoria ambiental................................................... 27

1.5.1 Itens essenciais à aplicação da auditoria ambiental.............. 31

1.6 Auditoria ambiental de certificação ISO 14001.................................... 32

1.6.1 O surgimento das normas ambientais internacionais........... 33

1.6.2 A participação brasileira na elaboração da série ISO 14001. 35

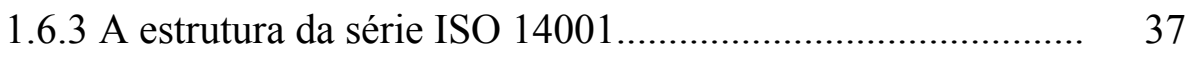

1.6.4 Norma brasileira ISO 14001.............................................. 42

2. OBJETIVOS

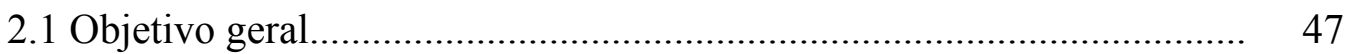

2.2 Objetivos específicos................................................................ 47

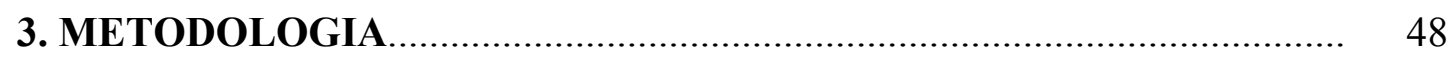

3.1 Delineamento do estudo................................................................... 48

3.2 Local de estudo............................................................................ 48

3.3 População de estudo................................................................................ 49

3.4 Instrumento para coleta de dados...................................................... 50

3.5 Análise dos resultados................................................................ 50

3.6 Aspectos Éticos...................................................................... 52

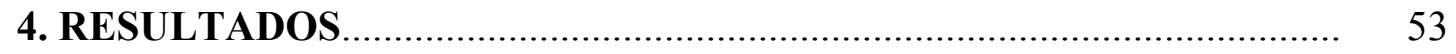

4.1 População de estudo.............................................................................. 54

4.1.1 Seleção dos entrevistados................................................... 54 
4.1.2 Caracterização dos entrevistados....................................... 54

4.2 Conhecimento dos funcionários do "Chão de Fábrica"........................ 103

5. DISCUSSÃ

5.1 População de estudo........................................................................ 106

5.2 Pesquisa com funcionários do "Chão de Fábrica”............................... 107

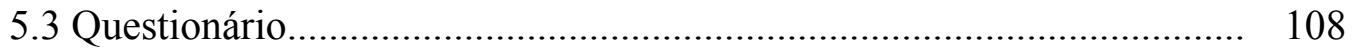

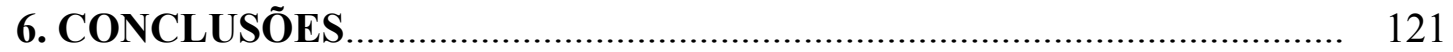

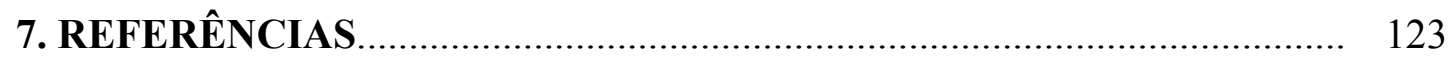

8. BIBLIOGRAFIA CONSULTADA....................................................... 128

\section{ANEXOS}

Anexo 1- Consolidação das informações das empresas

Anexo 2- Questionário "Chão de Fábrica"

Anexo 3- Questionário

Anexo 4- Termo de consentimento

Anexo 5- Comitê de ética

Anexo 6- Níveis de abordagem convencional e consciente

Anexo 7- Estatísticas das Certificações ISO 14001 


\section{LISTA DE TABELAS E FIGURAS}

Tabela 1: Legislação estadual que torna obrigatória a realização de auditorias.

Tabela 2: Quadro demonstrativo da série ISO 14001.

Tabela 3: Quadro dos níveis de abordagem convencional e consciente.

Figura 1: Relação cliente - auditor - auditado

Figura 2: Árvore ISO 14001

Figura 3: Ciclo PDCA

Figura 4: Distribuição dos entrevistados segundo formação universitária.

Figura 5: Distribuição dos entrevistados segundo gênero.

Figura 6: Tempo de empresa (anos) referido pelos entrevistados.

Figura 7: Freqüência de entrevistados que atuam na área ambiental.

Figura 8: Motivos referidos pelos entrevistados para certificação.

Figura 9: Grau de conhecimento adquirido pelos entrevistados.

Figura 10: Grau de aceitação apontado pelos entrevistados.

Figura 11: Mudanças ocorridas dentro da empresa após a certificação.

Figura 12: Foto representativa dos painéis de orientação.

Figura 13: Foto da linha de montagem antes do processo de certificação.

Figura 14: Foto da linha de montagem após o processo de certificação.

Figura 15: Mudança de imagem da empresa após a certificação.

Figura 16: Maiores dificuldades encontradas durante a certificação.

Figura 17: Facilidades obtidas com a ISO 14001 referidas pelos entrevistados.

Figura 18: Opiniões dos entrevistados sobre a legislação ambiental atual.

Figura 19: Principais benefícios percebidos com a certificação, na opinião dos entrevistados.

Figura 20: Relação empresa - fornecedores, na opinião dos entrevistados.

Figura 21: Relação empresa - concessionários, na opinião dos entrevistados.

Figura 22: Resultados atingidos com a certificação referidos pelos entrevistados.

Figura 23: Respostas apresentadas pelos funcionários de "chão de fábrica".

Figura 24: Custo de um SGA. 


\section{INTRODUÇÃO}




\title{
1. INTRODUÇÃ̃O
}

\subsection{Introdução à Problemática Ambiental}

\author{
Desenvolvimento sustentável é aquele que \\ atende às necessidades do presente sem \\ comprometer a capacidade de as gerações \\ futuras atenderem também às suas. \\ (Conceito de Desenvolvimento Sustentável \\ estabelecido pela Comissão Brundtland - Nosso \\ Futuro Comum, 1987)
}

A degradação das condições ambientais e sociais, que afeta a qualidade de vida, e o aumento da sensibilidade de indivíduos e de grupos da sociedade para estas questões são alguns dos elementos que têm colocado em evidência a crescente necessidade da gestão ambiental como parte de um processo orientado para a obtenção de sociedades sustentáveis.

De fato, a gestão ambiental tem sido entendida como o conjunto de ações sobre o meio natural que afeta ou é impactado por uma atividade produtiva ou uma organização. O significado etimológico dos dois vocábulos - gestão e ambiental tem suas raízes na língua latina. $\mathrm{O}$ vocábulo gestão originou-se de gestioni, que exprime o ato de gerir; ter gerência sobre; administrar; dirigir. O vocábulo ambiental é o adjetivo relativo a, ou próprio de ambiente*.

A palavra ambiente, por sua vez, foi formada de outros dois termos latinos: a preposição $a m b$ (ao redor de, à volta de) e o verbo ire (ir). A soma dos dois resultou ambire, cujo particípio presente, ainda em latim, é ambientis. Assim, é fácil entender que ambiente é tudo o que está ao redor. Indo um pouco mais longe no conceito etimológico, ambiental é o adjetivo que qualifica as coisas e os elementos que estão à volta de um determinado ser. Cabe destacar ainda que os termos meio, ambiente e meio ambiente são freqüentemente usados como sinônimos (COIMBRA 2002). 
Com base nesses conceitos, gestão ambiental é o ato de administrar, dirigir ou reger as partes constitutivas do meio ambiente. Para entender a abrangência e o alcance dessa definição, destaca-se que gestão ambiental é o ato de administrar, de dirigir ou reger os ecossistemas naturais e sociais em que se insere o homem, individual e socialmente, num processo de interação entre as atividades que exerce, buscando a preservação dos recursos naturais e das características essenciais do entorno, de acordo com padrões de qualidade. O objetivo último é estabelecer, manter ou recuperar o equilíbrio entre a natureza e o homem (PHILIPPI JR \& BRUNA 2003).

Com a Conferência das Nações Unidas sobre Meio Ambiente e Desenvolvimento, também conhecida por RIO-92, a gestão ambiental consagrou-se como instrumento de desenvolvimento sustentável.

Não menos importante para compreender as diversas formas de gestão ambiental é a abordagem que fundamenta a adoção "voluntária" de mecanismos e indicadores de performance em questões ambientais e sociais. Por real necessidade ambiental ou competitiva e, em alguns casos, somente por oportunidade de "marketing", os agentes econômicos e sociais têm se mobilizado para adotar sistemas de gestão do meio ambiente.

À gestão ambiental têm-se incorporado outros meios. Instrumentos como a certificação de gestão das normas ISO 14000 buscam sinalizar, ao mercado, atitudes das organizações produtivas que se consideram socialmente responsáveis. Na escala pública, ampliam-se os debates e as propostas para a incorporação de instrumentos de cunho econômico para tornar mais efetiva a gestão ambiental (MOREIRA 2001).

Durante as décadas de 60 e 70, as indústrias passaram a ampliar a aplicação de tecnologias de controle de poluição, adotando métodos de tratamento para suas emissões de poluentes, acompanhando os movimentos internacionais. Essas tecnologias se consolidaram naquela época e hoje são reconhecidas como tecnologias de "fim de tubo", ou seja, corretivas, destinadas tão somente à eliminação dos 
poluentes depois de gerados pelo processo produtivo (VILHENA \& POLITI 2000). Por outro lado, certos processos, especialmente os das indústrias químicas, petroquímicas e de energia, estavam sujeitos a graves acidentes como, por exemplo, explosões, vazamentos tóxicos, incêndios, dentre outros. Para evitar acidentes e minimizar as conseqüências, foram desenvolvidos e implementados diversos dispositivos de segurança.

No entanto, aconteceram vários acidentes industriais no final da década de 70 e durante a década de 80 , o que demonstrou que os problemas ainda não estavam resolvidos. Acidentes como o caso Seveso, em julho de 1976, na Itália, causado pela fusão da válvula de um reator químico da empresa Icmesa, resultando em um vazamento de gases tóxicos que atingiu 1.970 hectares em regiões no norte da Itália; o caso Bhopal, em dezembro de 1984, na Índia, causado pela elevação de temperatura e pressão em reservatório da indústria química Union Carbide, resultando no vazamento de isocianato de metila e conseqüente morte de 3.000 pessoas; e até mesmo o acidente com a cápsula de Césio 137, em setembro de 1987, em Goiânia, no Brasil (SOARES 2000). Fruto de um total descaso institucional, uma bomba de Cs137 desativada, encontrada em uma clínica abandonada, foi retirada do local por dois catadores de papel que a levaram para suas casas, causando uma tragédia. Esta deixou um rastro de quatro mortes reconhecidas por contaminação radioativa, entre quatorze registradas, cerca de 240 feridos e 3,4 mil toneladas de resíduos*.

Esses acidentes mostraram que sempre há causas gerenciais por trás das questões técnicas. Estas questões gerenciais envolvem usualmente problemas decorrentes da falta de comprometimento da alta administração, diretores, supervisores e gerentes; capacitação inadequada de funcionários e deficiências no treinamento das empresas; condições insuficientes para a adoção de medidas de prevenção, equacionamento e solução de problemas ambientais; entre outras.

A identificação de causas, tanto gerenciais quanto técnicas, que possam ser responsáveis por acidentes ou problemas ambientais, pode ser feita por meio de um 
instrumento poderoso, a auditoria, já utilizado pelas empresas nas áreas contábeis, de insumos e de distribuição. De forma semelhante, o instrumento da auditoria passa a ser visto como peça importante para a identificação, prevenção e controle de problemas ambientais.

Surge, assim, a auditoria ambiental, hoje considerada uma das ferramentas mais importantes da gestão ambiental, que pode ter sido pioneiramente adotada na década de 70. Como conseqüência de um acidente ocorrido em 1977, a indústria química Allied Chemical Corporation foi uma das primeiras a implementar esta ferramenta devido às pressões das agências regulamentadoras, depois do acidente em sua unidade no Estado da Virgínia - EUA. Neste caso, exames médicos constataram, em uma funcionária da empresa que apresentava sintoma de vertigens, uma contaminação com pesticidas produzidos na fábrica. O processo de auditoria, que tinha por objetivo verificar o cumprimento de todos os requisitos legais e dos padrões exigidos pela corporação, acabou por culminar no fechamento da unidade. Além da preocupação com a conformidade legal de suas atividades, as empresas estavam preocupadas em identificar os potenciais riscos para a saúde pública ou ao meio ambiente gerados no seu processo produtivo. Em 1978, a Allied estabeleceu um programa corporativo de auditorias de meio ambiente, saúde e segurança ocupacional, um dos primeiros do seu tipo (KENNEDY 1994).

No final da década de 80 , muitas empresas internacionais iniciaram programas de prevenção, impulsionadas pelos problemas decorrentes dos acidentes ambientais, pelos crescentes custos de controle de poluição e pelo aumento das pressões sociais via movimentos ambientalistas. Conceitos como "tecnologias limpas" e "segurança inerente", que denotam preocupação com as questões ambientais e de segurança dos processos produtivos, começaram a ser difundidos. $\mathrm{O}$ Programa Atuação Responsável é um dos produtos gerados por esta evolução do pensamento industrial sobre meio ambiente (PHILIPPI JR \& AGUIAR 2003).

O Programa Atuação Responsável foi criado no Canadá em 1984. O programa vem sendo implantado em indústrias químicas em operação, em diversos 
países, tornando-se um instrumento de gerenciamento ambiental e de prevenção de acidentes, ou seja, de segurança e apoio à saúde ocupacional do trabalhador e de proteção ambiental. Este programa foi adotado no Brasil em 1990, pela Associação Brasileira da Indústria Química e de Produtos Derivados - ABIQUIM. Nesta época, o interesse pelas auditorias ambientais aumentou substancialmente e muitas normas de gestão ambiental e códigos de conduta passaram a incluir o tema em sua composição, como por exemplo, os princípios da Carta Empresarial para o Desenvolvimento Sustentável da Câmara Internacional do Comércio. Em 1986, a United States Environmental Protection Agency - USEPA lançou uma Declaração de Princípios de Auditoria Ambiental, condicionando o licenciamento ambiental à realização de auditorias ambientais (SMA 1997).

Com a realização da Conferência das Nações Unidas sobre Meio Ambiente e Desenvolvimento, no Rio de Janeiro, em 1992, foi proposta e aceita a implementação da ferramenta Auditoria Ambiental. Na ocasião, a ISO - International Standardization Organization comunicou sua decisão de desenvolver uma série de normas sobre gestão ambiental, visando atender ao aumento das pressões sociais e comerciais existentes, tendo entre seus objetivos a minimização e gerenciamento mais eficaz de riscos ambientais. Esta série de normas viria a ser a ISO 14000. É preciso ressaltar a importância desta nova série pois as normas não tinham como foco padrões técnicos específicos e sim como organizar e gerenciar ambientalmente atividades, produtos e serviços. Desenvolveu-se também uma estrutura para certificação dos sistemas de gestão ambiental por meio de auditorias (BIANCHI 2002).

Atualmente, têm surgido novas concepções de gestão empresarial, tendo como princípio o estabelecimento de uma política de qualidade ambiental, incorporando à atividade industrial as bases da promoção da sustentabilidade do desenvolvimento. Em conseqüência, as respostas ao novo quadro de exigências do mercado e das condições ambientais acarretaram profundas alterações. Empresas foram compelidas a, num primeiro momento, cumprir exigências normativas e legislativas. Num segundo momento, as empresas estabeleceriam uma forma de 
administrar e produzir levando-se em conta o fator ambiental. Desta forma, o princípio passou a ser a prevenção de práticas poluidoras e impactantes ao meio ambiente.

Para a identificação de possíveis problemas ambientais, o que permitirá caracterizar suas eventuais causas e efeitos, necessária para a adoção de medidas de prevenção e controle, revela-se como ferramenta indispensável a utilização da auditoria ambiental, peça fundamental para um sistema de gestão efetivo, eficiente e eficaz.

\subsection{Auditoria Ambiental: Conceitos}

Auditoria é um exame ou uma avaliação independente realizada por um especialista, que faça uso de julgamento profissional e comunique o resultado aos interessados (clientes). Ela pode ser restrita aos resultados de um dado domínio ou mais ampla, abrangendo aspectos operacionais, de decisão e de controle. Para se entender melhor o que é a auditoria de uma empresa, escopo deste trabalho, e qual a função do auditor, a publicação Manual de Auditoria Ambiental (LA ROVERE 2000) faz um paralelo desta com o exame médico de um indivíduo. A auditoria é o exame que o médico (auditor) faz em seu paciente (empresa) para verificar seu estado de saúde. Este pode ser aplicado periódica ou, eventualmente, no caso de suspeita de alguma disfunção do organismo (empresa). Pode ser específico para um determinado órgão do corpo humano (auditoria específica para um determinado setor da empresa) ou geral (abrange os setores da empresa: recursos humanos, financeiros, produção, meio ambiente). Caso seja detectada alguma falha no funcionamento do organismo do paciente (setor auditado) este será submetido a um tratamento (medidas corretivas adotadas na pós-auditoria) e a novos exames (novas auditorias).

A auditoria não deve ser confundida com fiscalização. As auditorias são programadas, as datas e os horários de trabalho são previamente estabelecidos e o 
auditado é comunicado com antecedência sobre o objetivo e o escopo do trabalho. Estas características a tornam muito diferente das inspeções realizadas pelos órgãos de fiscalização, que são realizadas sem aviso nem programação. Além disso, o auditor verifica se o objeto de auditagem está sendo adequadamente aplicado e informa a seu cliente os resultados dessa verificação. Não faz parte do papel do auditor definir as soluções para os problemas encontrados, isto é papel do auditado.

Há a concepção errônea de que um auditor ou uma auditoria tenha objetivo punitivo. Isto pode decorrer das sanções aplicadas a pessoas físicas e jurídicas que sofrem auditorias compulsórias, aplicadas por exigência do setor público. A auditoria é um processo de exame ou avaliação sistemático e independente que identificará conformidades e não conformidades do auditado para com o objeto de auditagem, apresentando-as ao contratante que, caso tenha interesse e recursos, tomará as medidas necessárias para a correção das não conformidades detectadas. Assim, o auditor deve ser visto não como um inimigo ou pessoa incômoda à empresa, mas como um colaborador desta (LA ROVERE 2000).

A auditoria ambiental é um instrumento utilizado pelas empresas para auxiliálas a controlar o atendimento a práticas, políticas, procedimentos e requisitos estipulados com o objetivo de evitar a degradação ambiental. Ela tem suscitado crescente interesse na comunidade empresarial e nos governos, sendo considerada uma ferramenta básica para obter maior controle e segurança do desempenho ambiental, bem como, para evitar e minimizar acidentes. Define-se, assim, auditoria ambiental como o procedimento de exame e avaliação periódica ou ocasional do comportamento de uma empresa em relação ao meio ambiente.

A Secretaria de Meio Ambiente do Estado do Rio de Janeiro, por meio da Lei $\mathrm{n}^{\mathrm{o}} 1.898 / 91$, estabelece que auditoria ambiental é “.... a realização de avaliações $e$ estudos destinados a determinar: I - os níveis efetivos ou potenciais de poluição ou de degradação ambiental provocados por atividades de pessoas físicas ou jurídicas; II - as condições de operação e de manutenção dos equipamentos e sistemas de controle de poluição; III - as medidas a serem tomadas para restaurar o meio 
ambiente e proteger a saúde humana; IV - a capacitação dos responsáveis pela operação e manutenção dos sistemas, rotinas, instalações e equipamentos de proteção do meio ambiente e da saúde dos trabalhadores".

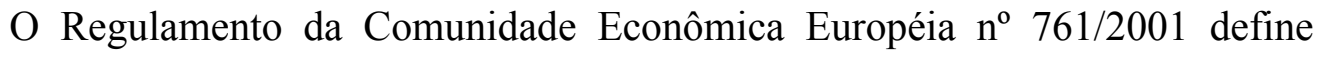
auditoria ambiental como "... um instrumento de gestão, que compreende uma avaliação sistemática, documentada, periódica e objetiva do comportamento da organização, do sistema de gestão e dos processos, com vista à proteção do ambiente e com o objetivo de: i. Facilitar o controle da gestão de práticas com eventual impacto no ambiente; ii. Avaliar a conformidade com as políticas ambientais, incluindo os objetivos e metas ambientais da organização" (CE 2001).

Nos Estados Unidos, foi desenvolvido pelo Elmwood Institute, da Universidade de Berkeley, Califórnia, trabalho que aprimorou este conceito para uma eco-auditoria: “.... análise e revisão das operações de uma organização sobre a perspectiva ecológica, motivados por mudança de valores na cultura da corporação: de dominação para parceria, de ideologia do crescimento econômico para a sustentabilidade ecológica. Envolve mudança de gestão mecanicista para gestão sistêmica. O resultado da eco-auditoria é a formulação de um plano de ação para minimizar o impacto ambiental da companhia e tornar sua operação ecologicamente responsável" (CALLENBACH et al. 1999).

A auditoria ambiental pode ser pública ou privada.

A auditoria ambiental privada tem sido impulsionada pela adoção de medidas de consciência ecológica pelas empresas, nos planos e estratégias de concorrência de novos produtos, de novas tecnologias e de novos sistemas de gestão. Além disso, a fusão de sociedades e a compra e venda de empresas tornaram indispensável a realização de auditorias ambientais para a constatação de eventuais passivos ambientais, sobre o qual ambos vendedores e compradores têm responsabilidade (responsabilidade civil objetiva, conforme $\S 1^{\circ}$, artigo 14, da Lei federal $n^{\circ} 6.938 / 81$; responsabilidade solidária, conforme artigo 942 do Código Civil). 
O reconhecimento do passivo ambiental se faz necessário nos processos de fusão e aquisição de empresas, pois caberá aos novos proprietários, não só o direito sobre a nova empresa, como também a responsabilidade pelos potenciais riscos em função do passivo ambiental herdado. Avalia-se o passivo ambiental de uma empresa através de auditoria especializada, com a identificação das não-conformidades com os requisitos legais e sua política ambiental (fase 1); e, em seguida, com a avaliação da área contaminada (fase 2), para que as soluções sejam valoradas monetariamente.

A auditoria ambiental deve ser realizada em um tempo pré-definido e deverá sujeitar-se à política ambiental da empresa e aos prazos de validade dos certificados de qualidade que lhe forem conferidos.

Quanto à auditoria ambiental pública, a Constituição Federal do Brasil estabelece em seu artigo 225, incisos I e IV, que sua realização, sob a responsabilidade dos órgãos oficiais, será sempre posterior ao estudo prévio de impacto ambiental exigido constitucionalmente para a instalação de obra ou atividade potencialmente causadora de significativa degradação do meio ambiente. Esta auditoria deverá avaliar se as orientações contidas no estudo, e incluídas na licença ambiental, estão sendo observadas e se os métodos de controle ambiental estão sendo eficazes.

A auditoria ambiental pública, no âmbito da Comunidade Econômica Européia, de acordo com o Regulamento $n^{\circ} 761 / 2001$, estabelece a obrigatoriedade destas serem realizadas por um auditor externo independente, com o nome de verificador ambiental, que deverá ser credenciado.

Atualmente alguns Estados, como por exemplo, o Rio de Janeiro, Minas Gerais, Ceará, Espírito Santo, Amapá, Paraná e Santa Catarina, tornaram obrigatória a realização de auditorias ambientais periódicas nas indústrias através da criação e promulgação de leis estaduais. 


\subsection{Tipos de Auditoria Ambiental}

A classificação das auditorias ambientais pode ser feita de acordo com o seu objetivo e segundo os critérios de auditoria (ALMEIDA 2000; LA ROVERE 2000; PHILIPPI JR \& AGUIAR 2003). São elas:

auditoria de conformidade legal (compliance) - usada para identificar a conformidade da unidade auditada com a legislação e os regulamentos aplicáveis;

auditoria de desempenho ambiental - identifica a conformidade da unidade auditada com a legislação, os regulamentos aplicáveis e indicadores de desempenho ambiental setoriais aplicáveis à unidade, bem como, para avaliar o cumprimento da política ambiental da empresa, caso esta exista;

auditoria de Sistema de Gestão Ambiental - avalia o cumprimento dos princípios estabelecidos no SGA pela própria empresa e sua adequação e eficácia. O Sistema de Gestão Ambiental corresponde ao conjunto inter-relacionado das políticas, práticas e procedimentos organizacionais, técnicos e administrativos de uma empresa que objetiva obter melhor desempenho ambiental, bem como controle e redução dos seus impactos ambientais;

auditoria de certificação ambiental - objetiva produzir uma declaração ou certificado, atestando que os critérios da auditoria estão sendo cumpridos pela organização auditada, em conformidade com os princípios estabelecidos na norma pela qual a empresa esteja desejando se certificar. No caso de certificação ambiental pela série ISO 14000, esta é muito semelhante à auditoria de sistema de gestão ambiental, porém deve ser conduzida por uma organização comercial e contratualmente independente da empresa, de seus fornecedores e clientes, que seja credenciada por um organismo específico;

auditoria de descomissionamento (decommissioning) - avalia a possibilidade de ocorrência de danos ao ecossistema e à população do entorno de alguma unidade 
empresarial por ocasião de sua desativação ou paralisação definitiva de suas atividades;

auditoria de acompanhamento - avalia se as condições estabelecidas na certificação continuam sendo cumpridas;

auditoria de verificação de correções (follow-up) - verifica se as nãoconformidades detectadas em auditorias anteriores foram corrigidas;

auditoria de responsabilidade (due diligence) - avalia possíveis riscos e custos associados ao passivo ambiental das empresas, é geralmente usada nas ocasiões de fusões, aquisições diretas ou indiretas de empresas ou de refinanciamento destas. Sua aplicação indica ao futuro comprador, parceiro, sócio ou outros, os possíveis riscos e responsabilidades ambientais da empresa em questão, valorando-os monetariamente, sempre que possível;

auditoria de sítios - avalia o estágio de contaminação de um local ou de áreas específicas;

auditoria compulsória - destinada ao cumprimento de exigências legais referentes à realização de uma auditoria ambiental;

auditoria pontual - objetiva otimizar a gestão dos recursos, melhorar a eficiência do seu processo produtivo e conseqüentemente minimizar a geração de resíduos, o uso de energia e de outros insumos. Em geral, este tipo de auditoria tem um objetivo específico, que pode ser a minimização dos resíduos, do uso de energia ou de matéria-prima, dentre outros.

Como um dos objetivos da auditoria é a certificação da conformidade de um produto, processo produtivo ou serviço com uma norma ou outro documento normativo especificado, habitualmente faz-se uso da Resolução CONMETRO $\mathrm{n}^{\circ}$ 02/97 do Conselho Nacional de Metrologia, Normalização e Qualidade Industrial, 
para classificar a auditoria de acordo com seus objetivos de certificação, conforme segue:

auditoria de primeira parte: realizada por auditores da própria organização auditada. Para manter imparcialidade e independência dos auditores, os funcionários de uma determinada área ou departamento de uma empresa auditam outra área, e assim sucessivamente. No final, a própria empresa declara, sob sua exclusiva responsabilidade, que um produto, processo ou serviço está em conformidade com a norma especificada. Em geral, o cliente da auditoria é a alta administração da empresa;

auditoria de segunda parte: realizada por auditores de uma parte diretamente interessada nos impactos ambientais da organização auditada. Tem-se como exemplo as auditorias realizadas pelo comprador no seu fornecedor, de modo a verificar se o produto, processo, serviço e sistema estão em conformidade com uma norma específica; ou aquelas conduzidas por possíveis compradores em processo de fusão ou aquisição de empresas; ou ainda realizadas por membros da comunidade afetada pelos impactos ambientais produzidos por uma organização;

auditoria de terceira parte: realizada por auditores sem interesse direto na gestão ambiental da organização auditada. Como exemplo tem-se a auditoria de certificação dos sistemas de gestão ambiental ISO 14001* (SILVA 2002).

É muito comum haver confusão entre as auditorias de primeira parte e as auditorias internas. São interpretadas como sinônimos, mas não o são. As auditorias internas são aquelas realizadas de acordo com os procedimentos internos da organização auditada, podendo ser de primeira parte, se realizadas com pessoal próprio, de dentro da empresa, ou de terceira parte, se realizadas por pessoal externo contratado para esse fim.

*Disciplina Auditoria Ambiental do Curso de Especialização em Direito Ambiental [CEDA-3] da Faculdade de Saúde Pública da Universidade de São Paulo. Professor: Alexandre de Oliveira e Aguiar. São Paulo; 2001. 


\subsection{Legislação Ambiental Aplicável}

As empresas no Brasil estão sujeitas a uma série de normas e leis ambientais. Estas disciplinam os padrões de qualidade ambiental; padrões de emissão de efluentes tanto na atmosfera, quanto nas águas e no solo; zoneamento industrial em áreas críticas de poluição; licenciamento; recursos hídricos; disposição final de resíduos; entre outros.

A conformidade com a legislação ambiental constitui-se na principal garantia que uma organização possui, em longo prazo, para desenvolver suas atividades de maneira socialmente responsável, gerenciando e minimizando seus aspectos e riscos ambientais. Assim sendo, a compreensão da legislação ambiental aplicável é ponto fundamental para aqueles que irão conduzir auditorias internas sobre sistemas de gestão ambiental (BUREAU VERITAS 1998).

Alguns estados brasileiros vêm adotando a auditoria ambiental como instrumento cuja realização deve ser determinada pelo Poder Público. Órgãos governamentais estaduais encarregados da implementação das políticas de proteção ambiental poderão, em certos casos, determinar a realização de auditorias periódicas ou ocasionais, estabelecendo diretrizes e prazos específicos. Nos casos de auditorias periódicas, os procedimentos relacionados à elaboração de diretrizes ambientais para aqueles empreendimentos deverão incluir consulta à comunidade afetada. As auditorias ambientais deverão ser realizadas às expensas dos responsáveis pela possível poluição ou degradação ambiental.

Os benefícios resultantes das auditorias ambientais públicas são similares aos das auditorias ambientais privadas: prevenção da poluição, redução na geração de resíduos, criação de vantagens competitivas de mercado, obtenção de retorno financeiro, entre outras.

Torna-se importante e extremamente relevante entender e compreender a evolução da legislação ambiental no Brasil, levando-se em consideração que os seus 
desdobramentos têm exercido pressões e influências cada vez maiores sobre as empresas, os órgãos governamentais e a sociedade civil organizada, pelas exigências que se impõem e que demandam adequação de conformidade legal e técnica.

\subsubsection{Evolução da legislação ambiental no Brasil}

$\mathrm{Na}$ primeira metade do século XX, a legislação ambiental no Brasil caracterizou-se por disposições pontuais sobre recursos naturais, como o Código de Águas de 1934 e o Código Florestal de 1965, além da concepção preservacionista da memória histórica e artística nacional, representada pela Lei de Tombamento de 1937.

As repercussões internacionais da Conferência das Nações Unidas sobre Meio Ambiente, conhecida por Conferência de Estocolmo, realizada em 1972, apesar da posição brasileira de colocar-se, naquele momento, como destinatária de tecnologias industriais obsoletas, contrariamente ao princípio da própria conferência, que era o de ser abolido o seu emprego, fizeram com que tivesse início a organização institucional da área ambiental no país.

Em 1973, criou-se, no Estado de São Paulo, a Companhia Estadual de Tecnologia de Saneamento Básico e de Controle da Poluição das Águas - CETESB, que teve sua denominação alterada em 1976 para Companhia de Tecnologia de Saneamento Ambiental e passou a ser vinculada à Secretaria de Estado do Meio Ambiente em 1987 (MOLLER 1998). No Estado da Bahia, promulgou-se a Lei $n^{\circ}$ 3.163/73, que estabeleceu a criação do Conselho Estadual de Proteção Ambiental CEPRAM vinculado à Secretaria de Estado de Planejamento, Ciência e Tecnologia, tendo sido o primeiro Conselho de Meio Ambiente do país. Também em 1973 é criada a Secretaria Especial do Meio Ambiente - SEMA; junto ao então Ministério do Interior, responsável pelo direcionamento de ações voltadas à proteção e melhoria do meio ambiente. 
As agências de proteção ambiental dos Estados do Rio de Janeiro e de Santa Catarina foram criadas no ano de 1975. A Fundação Estadual de Engenharia do Meio Ambiente - FEEMA e a Fundação de Amparo à Tecnologia e ao Meio Ambiente FATMA, respectivamente (SMA 1992).

A Lei n ${ }^{\circ} 997$ do Estado de São Paulo, promulgada em 1976, que dispõe sobre o controle da poluição do meio ambiente, instituiu o Sistema de Prevenção e Controle da Poluição do Meio Ambiente, o qual foi regulamentado no mesmo ano, através do Decreto Estadual $n^{\circ}$ 8.468. Este regulamento definiu a competência e as atribuições da CETESB, forneceu a classificação e os padrões de qualidade e de emissão nas águas, padrões de qualidade, de emissão, de condicionamento e projeto para fontes estacionárias no ar, dispôs sobre a poluição do solo e estabeleceu disposições para licenças e registro das fontes de poluição (SMA 1991).

Os padrões para emissões atmosféricas são restritos a poucos poluentes, e em processos bastante particulares, como transportes, combustão de óleos e carvão, fornos siderúrgicos, e alguns outros, apesar das fortes implicações da poluição atmosférica sobre a saúde. Esta situação pode ser reflexo de custos eventualmente elevados de controle e dificuldades operacionais em monitorar tais emissões. Por outro lado, isto se reflete nas empresas por uma ênfase em geral menor à questão da poluição atmosférica, em relação, por exemplo, a poluição das águas e aos resíduos, que têm legislação mais específica, e, paulatinamente, mais restritivas (DEUS et al. 2001).

Também a legislação referente a padrões de emissão não tem acompanhado avanços da tecnologia e o uso de novos produtos químicos. Estas limitações da legislação, quanto aos padrões de emissão, dificultam a orientação clara dos projetos e da gestão ambiental nas empresas, levando à aplicação de critérios subjetivos no gerenciamento dos projetos.

Somente em 1977, no Estado de Minas Gerais, é que surgiu um colegiado normativo e deliberativo com a participação da sociedade civil de uma forma mais 
ampla, possibilitando algum tipo de controle social na formulação e implementação de uma política pública ambiental, com a criação da Comissão de Política Ambiental - COPAM junto à Secretaria de Estado de Ciência e Tecnologia. RIBEIRO (2003) lembra que o desenvolvimento desse modelo e de seu aperfeiçoamento surgiu através das experiências dos Estados de São Paulo, Bahia, Rio de Janeiro, Santa Catarina e se disseminou pelo país, sendo adotado por outros Estados, como Sergipe (1978); Alagoas e Mato Grosso do Sul (1979).

Em 1980, através da Lei Federal nº 6.803, estabeleceram-se diretrizes básicas para o zoneamento industrial em áreas críticas de poluição, reconhecendo-se dessa forma os prováveis danos ao meio ambiente provocados por determinados empreendimentos industriais. Instituíram-se ademais, através dessa lei, estudos especiais de alternativas e de avaliações de impactos para a aprovação desses empreendimentos (CORRÊA 1986).

Em agosto de 1981, promulgou-se a Lei Federal $n^{0} 6.938$, que dispõe sobre a Política Nacional do Meio Ambiente e instituiu o Sistema Nacional de Meio Ambiente - SISNAMA - constituído por órgãos e entidades federais, estaduais e municipais responsáveis pela proteção ambiental, com o objetivo de determinar os mecanismos de formulação e aplicação dessa política. Foi denominado como órgão superior o Conselho Nacional de Meio Ambiente - CONAMA. O artigo 10 da referida lei, ao estabelecer as competências dos estados para conceder as licenças ambientais, fortaleceu ainda mais os órgãos ambientais estaduais. Surgiu pela primeira vez a compatibilização do desenvolvimento econômico social com a preservação da qualidade do meio ambiente. Essa lei consagrou o termo da responsabilidade civil objetiva, relativa a todo e qualquer dano ao meio ambiente, através do disposto no artigo $14, \S 1^{\circ}$ : “....é o poluidor obrigado, independentemente da existência de culpa, a indenizar ou reparar os danos causados ao meio ambiente e a terceiros, afetados por sua atividade". Estabeleceu como instrumentos da Política Nacional de Meio Ambiente, entre outros: os padrões de qualidade ambiental; o zoneamento ambiental em nível nacional, regional e municipal; a obrigatoriedade do 
estudo de impacto ambiental; o licenciamento e a revisão de atividades efetiva ou potencialmente poluidoras (MUKAI 1998).

A Lei Federal no 7.347, de 24 de julho de 1985, disciplinou a Ação Civil Pública de responsabilidade por danos causados ao meio ambiente, ao consumidor, a bens e direitos de valor artístico, estético, histórico, turístico e paisagístico. E prevê em seu artigo $5^{\circ}, \S 6^{\circ}$ a possibilidade de os órgãos públicos firmarem com os interessados Compromisso de Ajustamento de Conduta. Considerando a disseminada prática de denominar o citado instrumento como Termo de Ajustamento de Conduta - TAC, será adotado para o presente trabalho a denominação legal de Compromisso de Ajustamento de Conduta - CAC, por mostrar-se mais adequado, visto que os direitos tutelados por este instrumento são metaindividuais e indisponíveis, não havendo, portanto, possibilidade de transacionar-se sobre os mesmos, ou seja, na acepção técnica da palavra, dispor, ainda que parcialmente, do dever de reparar e preservar os bens ambientais e, conseqüentemente, do direito a um meio ambiente saudável.

A Resolução CONAMA n ${ }^{0}$ 01, de 23 de janeiro de 1986, determinou os critérios básicos e diretrizes gerais para o Relatório de Impacto Ambiental - RIMA. De acordo com esta resolução, os órgãos ambientais competentes e os órgãos setoriais do SISNAMA deverão compatibilizar os processos de licenciamento com as etapas de planejamento e implantação das atividades modificadoras do meio ambiente, respeitados os critérios e diretrizes estabelecidas e tendo por base a natureza, o porte e as peculiaridades de cada atividade.

Segundo Lemos 1981, no ano de 1986 já existiam conselhos estaduais de meio ambiente nos Estados do Amazonas, Alagoas, Bahia, Paraíba, Sergipe, Mato Grosso do Sul, Minas Gerais, Rio de Janeiro e Santa Catarina, abrangendo, portanto, as cinco regiões geográficas do nosso país. Atualmente, todos os vinte e seis Estados da Federação e o Distrito Federal possuem Conselho Estadual de Meio Ambiente e respectivos órgãos executivos. $\mathrm{O}$ primeiro resultado significativo foi a conscientização ambiental em todo o país, decorrente da participação de vários 
setores do governo e da sociedade civil nas discussões dos conselhos e os reflexos indiretos das ações desses conselheiros, que se tornaram agentes de transformação social (LEMOS 1981; RIBEIRO 2003).

A Constituição Federal Brasileira, promulgada em 05 de outubro de 1988, contém capítulo específico destinado às questões ambientais. O capítulo VI do Título VIII - Da Ordem Social - contém o artigo 225, que diz: "Todos têm direito ao meio ambiente ecologicamente equilibrado, bem de uso comum do povo e essencial à sadia qualidade de vida, impondo-se ao Poder Público e à coletividade o dever de defendê-lo e preservá-lo para as presentes e futuras gerações".

Essa Constituição consolidou também a descentralização quanto às competências legislativas. De acordo com o artigo 23, inciso VI, todos os entes federativos (União, Estados, Distrito Federal e Municípios) têm competência legislativa e político-administrativa para proteger o meio ambiente e combater a poluição em qualquer de suas formas.

As Leis Federais $n^{\circ} 7.804 / 89$ e 8.028/90 alteraram posteriormente a Lei Federal $n^{\circ}$ 6.938/81, adequando-a aos princípios constitucionais (MOLLER 1998).

As Constituições Estaduais, de modo geral, delegaram ao Poder Público a incumbência de fiscalizar, planejar e executar atividade de preservação dos ecossistemas; estabeleceram interdições às práticas degradadoras; fixaram a obrigatoriedade de realização de Relatórios de Impacto Ambiental; criaram os Conselhos Estaduais do Meio Ambiente e procuraram resguardar a qualidade de vida da população. Em 1989, os Estados do Amapá, Pará, Rondônia, alguns outros situados na região Nordeste do país e São Paulo promulgaram suas Constituições Estaduais. A Constituição do Estado de São Paulo, de 1989, dedicou o capítulo IV ao Meio Ambiente e estabeleceu a criação de um sistema de administração da qualidade ambiental, proteção, controle e desenvolvimento do meio ambiente e uso adequado dos recursos naturais (SMA 1991). 
Os municípios também devem exercer o controle sobre atividades efetiva ou potencialmente poluidoras, como prevê a Constituição Federal. A Lei Orgânica do Município de São Paulo estabelece alguns princípios, quais sejam, a prevalência do interesse público; o meio ambiente como bem de uso comum do povo; o acesso à informação; a efetiva participação da população na defesa e preservação ambiental; a compatibilização das políticas econômicas, de saúde, social e educativa nos diferentes níveis de governo. Dentre os objetivos dessa lei, destaca-se a criação do Conselho Municipal do Meio Ambiente, a educação ambiental, o controle da poluição do ar, o controle da degradação do solo, a poluição da água e o controle da poluição sonora (MOLLER 1998).

O Instituto Brasileiro do Meio Ambiente e dos Recursos Naturais Renováveis - IBAMA - através da Portaria nº 96, de outubro de 1996, estabeleceu os critérios para o Cadastro Técnico Federal de Atividades Potencialmente Poluidoras ou Utilizadoras de Recursos Ambientais. Esse cadastro é obrigatório para todas as atividades industriais, de extração, comercialização e transporte de produtos potencialmente perigosos ao meio ambiente.

A Resolução CONAMA no 237, de 19 de dezembro de 1997, dispõe sobre a revisão de procedimentos e critérios utilizados pelo Sistema de Licenciamento Ambiental instituído pela Política Nacional de Meio Ambiente. Estabeleceu a obrigatoriedade de prévio licenciamento pelo órgão ambiental competente, sem prejuízo de outras licenças legalmente exigíveis, para a localização, construção, instalação, ampliação, modificação e operação de empreendimentos e atividades utilizadoras de recursos ambientais consideradas efetiva ou potencialmente poluidoras, bem como os empreendimentos capazes de causar degradação ambiental. Esta licença ambiental depende de prévio estudo de impacto ambiental e respectivo relatório de impacto sobre o meio ambiente (EIA/RIMA), ao qual se deve dar publicidade, garantida a realização de audiências públicas, quando couber, de acordo com regulamentação. 
Já em 12 de fevereiro de 1998, foi promulgada a Lei Federal $\mathrm{n}^{0}$ 9.605, conhecida por Lei de Crimes Ambientais. Ela prevê penas de ordem administrativa, civil e criminal para a autoria ou co-autoria em condutas lesivas ao meio ambiente. Responsabilizam-se, através dessa lei, as pessoas físicas e jurídicas que cometerem crimes ambientais e determinam-se as penas cabíveis que vão desde multas e prestação de serviços à comunidade até a suspensão parcial ou total de atividades e interdição temporária de estabelecimento, obra ou atividade. Essa lei atendeu a necessidade de complementar e regulamentar a Lei Federal $n^{0} 6.938 / 81$ e a Constituição Federal de 1988, e, de certa forma, às recomendações da Carta da Terra e da Agenda 21, aprovadas por ocasião da Conferência RIO-92, no Rio de Janeiro, onde os países signatários se comprometeram a criar legislação específica para a responsabilização por danos ao meio ambiente e para compensação às vítimas da poluição.

No mês de dezembro de 2002, o Decreto Estadual no 47.397/02 modificou substancialmente o licenciamento ambiental no Estado de São Paulo. O decreto estabelece, entre outras coisas, a obrigatoriedade de cada empreendimento renovar as suas licenças no prazo máximo de cinco anos e, a partir daí, essas licenças terão prazo de validade de dois a cinco anos. Além disso, toda vez que um estabelecimento industrial estiver sendo desativado deverá realizar uma auditoria ambiental. É de suma importância acompanhar as alterações introduzidas pelos decretos, resoluções e portarias na regulamentação ambiental, pois estas representam os anseios, exigências, enfim, demandas de uma sociedade em evolução.

Do ponto de vista das empresas, a necessidade de licenciamento ambiental prévio implica em dificuldades que, para aquelas que têm uma postura ambiental reativa, são vistas como complicadoras para seus projetos. Entre esses fatores complicadores, destacam-se os necessários planejamento e estudos que demandam tempo e recursos maiores do que os que costumavam ser previstos nos respectivos projetos. Além disso, o tempo utilizado para análise dos projetos pelos órgãos ambientais tem sido maior que o aceitável pelo empresariado, prejudicando uma 
maior velocidade nos investimentos. Os órgãos públicos se defendem alegando que os prazos são os necessários para análise dos projetos, com os recursos que dispõem.

Outra questão crítica é o custo do licenciamento, representado por estudos de impacto ambiental, publicações de pedidos de licença, e, em muitos casos, serviços de consultoria ambiental que intermediam o contato de empresas com os órgãos ambientais (DEUS et al. 2001).

Por último, muitas empresas temem fornecer informações aos órgãos públicos, que possam servir de base para a fiscalização. Acreditam que, não fornecendo informações sobre seus processos, inclusive ampliações e modificações, estão menos sujeitos à fiscalização. Surge assim um dilema, ou seja, o instrumento que foi criado para prevenir e controlar os impactos das atividades de uma empresa sobre o meio ambiente, na realidade, se não fornecido corretamente, pode aumentar o risco de ações civis e criminais contra as próprias empresas. Assim, é necessário estabelecer alguma forma de proteção para as informações corretamente fornecidas aos órgãos públicos.

Nos Estados Unidos também se constata algo similar, o que tem suscitado diversos debates sobre a legitimidade ou não de se proteger as informações ambientais obtidas por meio de auditorias. De um lado, tem-se o temor legítimo dos empresários quanto à possibilidade de estarem municiando ações contra si próprios. De outro, tem-se uma legítima discussão de fundo sobre a natureza jurídica das informações ambientais, tendo em vista o interesse da coletividade em conhecer conseqüências ambientais das várias atividades econômicas e seus possíveis riscos ou efeitos indesejáveis à saúde pública e ao meio ambiente.

No Brasil existem numerosas leis que regulamentam o uso dos recursos naturais e a proteção ao meio ambiente, e alguns Estados e Municípios mais industrializados ou mais avançados politicamente vêm promulgando leis que tornam obrigatória a realização de auditorias ambientais periódicas nas indústrias (Tabela 1). Já estão sendo elaborados bancos de dados informatizados contendo a legislação 
ambiental federal existente e a legislação referente a alguns estados e municípios onde a demanda por essa informação é maior, muitas vezes decorrente da alta concentração de atividades empresariais nessas regiões. $O$ incremento da legislação ambiental, bem como as normas da série ISO 14000, têm impulsionado a elaboração desse banco de dados.

O Estado do Rio de Janeiro foi a primeira unidade política a regulamentar a auditoria ambiental, promulgando a Lei $\mathrm{n}^{\mathrm{o}} 1.898$ em novembro de 1991. Seu objetivo principal é obrigar as empresas de elevado potencial poluidor, como as refinarias, indústrias petroquímicas, siderúrgicas, químicas, alimentícias, de bebidas e instalações portuárias, a realizarem auditorias ambientais anuais, pagas pelas próprias empresas e realizadas por equipes técnicas independentes, com periodicidade anual. Esta lei foi suplementada por dois regulamentos e alterada parcialmente pelas Leis $\mathrm{n}^{\circ}$ $3.341 / 99$ e $3.471 / 00$.

O Estado de Minas Gerais promulgou a Lei n ${ }^{\circ}$ 10.627, em janeiro de 1992. Esta lei não foi regulamentada até agora e é em grande parte cópia literal da lei carioca. Introduz algumas poucas mudanças, como por exemplo, o estabelecimento de um prazo mínimo de três anos entre a realização das auditorias ambientais obrigatórias e, com respeito ao acesso do público às informações da auditoria, preserva o sigilo industrial.

Em julho de 1993, a Lei $\mathrm{n}^{\mathrm{o}} 12.148$ foi promulgada, instituindo as auditorias ambientais no Estado do Ceará. Esta lei estabelece que as auditorias devem ser realizadas anualmente e lista em seu artigo $4^{\circ}$ quais empresas ou atividades potencialmente poluidoras estarão sujeitas. Alguns dispositivos foram alterados e outros adicionados através da Lei n. ${ }^{\circ}$ 12.685, de 09 de maio de 1997.

Em agosto de 1993, o Estado do Espírito Santo promulgou a Lei $\mathrm{n}^{\circ} 4.802$, regulamentada, em dezembro de 1994, pelo Decreto ${ }^{\text {o }} 3.795-N$. Esta lei determina a execução de auditorias ambientais para as mesmas atividades e empreendimentos listados pela lei carioca, acrescentando, ainda, as indústrias de papel e celulose, as 
atividades de mineração e as unidades de disposição de resíduos hospitalares. Existe ainda a Lei $\mathrm{n}^{\mathrm{o}} 3.968$, do Município de Vitória, promulgada e regulamentada em setembro de 1993. É essencial haver uma harmonização e compatibilização das exigências impostas pelas leis ambientais que regulamentam as auditorias ambientais, aplicáveis a um mesmo local. Por exemplo a uma empresa, que é localizada no Município de Vitória, é aplicável a legislação municipal assim como a legislação estadual. Ambas devem ser cumpridas, porém, em geral, a legislação municipal é mais restrita (LA ROVERE 2000).

O Estado do Paraná publicou, através do Conselho Estadual do Meio Ambiente, a Resolução CEMA n ${ }^{\circ}$ 007, em maio de 2001. Esta resolução foi motivada por um acidente ocorrido no estado, que resultou em derramamento de óleo, e estabelece a obrigatoriedade das empresas com atividades na área de petróleo a realizar auditoria ambiental independente em suas instalações industriais, marítimas e terrestres. As auditorias devem seguir diretrizes específicas anexas ao texto da resolução, além das que foram instituídas pela Resolução CONAMA nº 265, de janeiro de 2000 (SALLES 2001).

Tabela 1: Legislação estadual que torna obrigatória a realização de auditorias.

\begin{tabular}{||c|c|c|c|c||}
\hline Ceará & Espírito Santo & Minas Gerais & Paraná & Rio de Janeiro \\
\hline Lei Estadual & Lei Estadual & Lei Estadual & Resolução & Lei Estadual \\
$\mathrm{n}^{\mathbf{0}} 12.148 / 93$ & $\mathrm{n}^{\mathbf{0}} 4.802 / 93$ & $\mathrm{n}^{\mathbf{o}} 10.627 / 92$ & CEMA & $\mathrm{n}^{\mathbf{o}} 1.898 / 91$ \\
& & & $\mathrm{n}^{\mathbf{0}} 007 / 01$ & \\
\hline
\end{tabular}

\subsubsection{Princípios relevantes do direito ambiental}

Suspeitando-se que uma atividade industrial traz riscos ao ambiente, devem o Poder Executivo e o Judiciário assumir o pior e proibi-la, ou regulá-la, impondo-lhe padrões de segurança rigorosos? Ou, diversamente, deve a intervenção pública ocorrer somente quando o potencial ofensivo tenha sido claramente demonstrado 
pelo órgão de controle ambiental ou por organizações não-governamentais, amparados num raciocínio de probabilidade? (DEUS et al. 2001)

A precaução separa bem o Direito Ambiental de outras disciplinas jurídicas tradicionais, porque a responsabilização civil e criminal clássica tem como prérequisitos fundamentais "certeza" e "previsibilidade", exatamente os dois condicionantes que a norma ambiental procura afastar, porque o dano ambiental nunca é certo ou previsível, ele acontece. Com isso, pode-se dizer que esta situação levou à criação de um princípio, o da precaução, que inaugura uma nova fase para o próprio Direito Ambiental. Este princípio surgiu na Conferência de Estocolmo em 1972, e foi reafirmado na Conferência das Nações Unidas sobre Meio Ambiente e Desenvolvimento, a Conferência do Rio, em 1992 (MANETTI et al. 2001).

Segundo este Princípio da Precaução, já não cabe aos titulares do direito provar efeitos negativos de empreendimentos levados à apreciação do Poder Executivo ou Poder Judiciário, como é o caso de instrumentos filiados ao regime de simples prevenção, como o Estudo de Impacto Ambiental, o Inventário de Resíduos, o Laudo Técnico, entre outros. Nesses casos, cabe ressaltar que uma das razões é a disponibilidade de informações cobertas por segredo industrial nas mãos de empreendedores. De acordo com BENJAMIN (1998), é preciso impor aos degradadores o ônus de corroborar a inofensividade de sua atividade proposta, principalmente naqueles casos onde eventual dano possa ser irreversível, de difícil reversibilidade ou de larga escala.

Já o Princípio do Poluidor - Pagador é aquele que impõe ao poluidor o dever de arcar com as despesas de prevenção, reparação e repressão da poluição. Este princípio estabelece que o causador da poluição e da degradação dos recursos naturais deve ser o responsável principal pelas conseqüências de sua ação ou omissão. Em síntese, é o princípio que visa imputar ao poluidor os custos sociais da poluição por ele causada, prevenindo, ressarcindo e reprimindo os danos ocorridos, não apenas a bens e pessoas, mas também à própria natureza. 
A Declaração do Rio, em 1992, agasalhou a matéria em seu princípio 16, dispondo que ".... as autoridades nacionais deveriam procurar fomentar a internalização dos custos ambientais e o uso de instrumentos econômicos, tendo em conta o critério de que o que contamina deveria, em princípio, arcar com os custos da contaminação, tendo devidamente em conta o interesse público e sem distorcer o comércio nem as inversões internacionais".

No Brasil, a Lei $n^{0}$ 6938/81, que dispõe sobre a Política Nacional do Meio Ambiente, acolheu o princípio do poluidor-pagador em seu artigo $4^{\circ}$, inciso VII, estabelecendo, como um de seus fins, “.... a imposição, ao poluidor e ao predador, da obrigação de recuperar e/ou indenizar os danos causados”.

Este importante princípio foi ainda incorporado pela Constituição Federal de 1988, no artigo 225, mais precisamente no parágrafo $3^{\circ}$, quando determina a sujeição dos poluidores, pessoas físicas ou jurídicas, às sanções penais e administrativas, independentemente da obrigação de reparar os danos causados.

Por sua vez, o Princípio do Usuário - Pagador, que vem sendo discutido, partindo do princípio do poluidor-pagador, estabelece que os preços devem refletir todos os custos sociais do uso e esgotamento do recurso. No sistema tradicional em vigor, aquele que utiliza um dado recurso comum, de titularidade coletiva, não vem sendo chamado a compensar a sociedade pelo seu uso. Em termos técnicos, tem-se aí uma hipótese de subsídio, que só pode ser evitada se o usuário pagar pelo consumo do bem, que é de todos, incorporando-se tal custo, como se dá com o princípio do poluidor-pagador, no preço final de produtos e serviços. Ora, se o recurso é coletivo, apenas alguns poucos o estão utilizando sem qualquer compensação, então a conta deste uso está sendo coberta pela coletividade. Mais grave, se a coletividade tiver ainda preocupação com uma atuação irresponsável e oportunista destes sujeitos, ela não só não é compensada pelo uso do bem, como ainda tem que arcar com despesas destinadas a protegê-lo. Aqui é perfeita a analogia com comerciantes que são forçados a pagar "proteção" a sindicatos do crime com o propósito de evitar ataques enquanto conduzem sua atividade econômica, legítima e legal. De modo 
assemelhado, os não-usuários do recurso comum são também obrigados a pagar "proteção" ao Estado, via impostos, e à intermediários - por exemplo, ONG's, tudo para "evitar perder o acesso ao recurso que originariamente era seu”" (BENJAMIN 1998).

$\mathrm{Na}$ lista dos princípios que influenciam diretamente o regime de responsabilidade civil pelo dano ambiental, a Constituição Federal consagra também o Princípio da Reparabilidade Integral do dano ambiental. Por esse princípio, são vedadas todas as formas e fórmulas, legais ou constitucionais, de exclusão, modificação ou limitação da reparação ambiental, que deve ser sempre integral, assegurando proteção efetiva ao meio ambiente ecologicamente equilibrado (BENJAMIN 1998).

Como se sabe, muitos dos princípios incorporados nessas definições advêm de debates e acordos internacionais. Assim, o princípio da responsabilidade ambiental, que se encontra no item 22 da Declaração de Estocolmo (1972) e foi ratificado no item 13 da Declaração do Rio de Janeiro (1992), estabelece:

"Os Estados devem cooperar para continuar desenvolvendo o direito internacional, no que se refere à responsabilidade e à indenização das vítimas da poluição e outros danos ambientais, que as atividades realizadas dentro da jurisdição ou sob controle de tais Estados, causem às zonas situadas fora de sua jurisdição” (Estocolmo, 1972 - Princípio 22).

"Os Estados devem elaborar uma legislação nacional concernente à responsabilidade por danos causados pela poluição e com a finalidade de indenizar as vítimas" (Rio de Janeiro, 1992 - Princípio 13).

Houve a consagração do princípio também na legislação federal, por meio da Lei $\mathrm{n}^{\mathrm{o}} 6938 / 81 \mathrm{em}$ seu artigo $14, \S 3^{\circ}$ combinado com o artigo $3^{\circ}$, inciso IV. O artigo $14, \S 3^{\circ}$ traz o dever do poluidor reparar ou indenizar os danos causados por sua atividade e o artigo $3^{\circ}$, inciso IV define o conceito de poluidor (DEUS et al. 2001). 
Tal princípio foi consagrado pela Constituição brasileira em seu artigo 225, $\S 3^{\circ}:$

“As condutas e atividades consideradas lesivas ao meio ambiente sujeitarão os infratores, pessoas físicas e jurídicas, a sanções penais e administrativas, independentemente da obrigação de reparar os danos causados".

\subsection{Planejamento de Auditoria Ambiental}

Para o planejamento e preparação de uma auditoria ambiental devem ser definidos os seus elementos-chave, que são: objetivo; escopo; critérios que serão adotados; recursos necessários; equipe de auditores e respectivas responsabilidades; e datas de realização da auditoria in loco.

O objetivo deverá ser definido visando atender às necessidades e expectativas do cliente.

O escopo, uma vez determinado, delimita o campo de atuação da auditoria, de acordo com seu objetivo. Para a determinação do escopo são considerados: a localização geográfica, reconhecendo-se onde será realizada a auditoria; os limites organizacionais, com a delimitação das unidades e das áreas funcionais da empresa que serão auditadas; o objeto de auditagem, que será auditado; o período, com a definição da data a partir da qual serão levantadas as informações e as evidências de conformidade e não-conformidade da unidade auditada; e o tema ambiental, com a definição dos itens que serão avaliados: poluição da água, do ar, geração de resíduos, riscos ambientais.

Os critérios que serão adotados na auditoria correspondem às práticas, políticas, procedimentos ou regulamentos legais que servirão como referência para a coleta das evidências. Eles serão selecionados em função do objetivo e do escopo previamente determinados, e deverão ser descritos minuciosamente. 
O auditado deve fornecer os recursos humanos, físicos e financeiros necessários para o desenvolvimento da auditoria, garantindo aos auditores as informações e elementos indispensáveis a sua plena realização (LA ROVERE 2000; MOREIRA 2001; DONAIRE 1999).

A equipe de auditores deve ter pleno conhecimento dos trabalhos a serem realizados e clara consciência dos objetivos a serem atingidos. A auditoria deve ser planejada e preparada com o objetivo de garantir que cada pessoa envolvida no processo de auditoria, incluindo auditores, administração e pessoal, compreenda bem as suas funções e responsabilidades.

A preparação deve incluir a familiarização com as atividades da organização e com o sistema de gestão ambiental nela instituído. Na hipótese da existência de auditorias anteriores, a equipe deverá conhecer e analisar, cuidadosamente, os resultados e conclusões obtidas.

De acordo com o artigo $2^{\circ}$ do Regulamento da CEE $n^{\circ} 761 / 2001$ : “.... auditor é a pessoa ou equipe, pertencente ou não aos quadros da organização, agindo em nome do órgão superior de administração da empresa, que dispõe, individual ou coletivamente, das competências necessárias, e de independência suficiente em relação às atividades que inspeciona para poder formular um juízo objetivo".

O auditor deve ter autocontrole, capacidade de analisar e expressar claramente idéias e conceitos, conduta ética, independência, organização pessoal, objetividade e perseverança. Os auditores devem ser suficientemente independentes em relação às atividades objeto da auditoria, para emitirem pareceres objetivos e isentos.

O auditado é a organização, seja companhia, corporação, firma, empresa ou instituição, ou parte ou combinação destas, pública ou privada, sociedade anônima, limitada ou com outra forma estatutária, com funções e estrutura administrativa próprias, que está sendo auditada. 


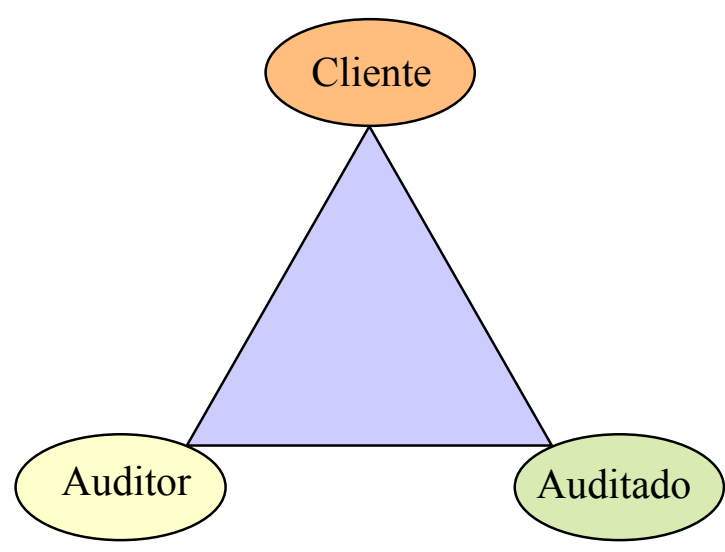

Figura 1: Relação cliente - auditor - auditado.

A realização da auditoria ambiental deve contar com, pelo menos, dois auditores, independente do tamanho da empresa auditada. A equipe de auditoria pode incluir também especialistas técnicos e auditores em treinamento. $\mathrm{O}$ especialista técnico é uma pessoa que provê conhecimentos ou habilidades específicas à equipe de auditoria, porém não participa como um auditor.

Em geral, um dos auditores da equipe desempenha a função de auditor-líder. Este auditor-líder é o responsável por garantir a eficiente condução e conclusão dos trabalhos. Deve ser uma pessoa qualificada e ter ciência de que os resultados da auditoria somente podem ser comentados e divulgados às partes interessadas, ou seja, aos demais membros da equipe, ao auditado, ao cliente e a quem este recomendar. Nem sempre o auditado e o cliente são a mesma figura. Como no caso, por exemplo, de uma auditoria ser realizada pelo comprador no seu fornecedor. Assim, o fornecedor será o auditado e o comprador será o cliente. Porém, em muitos casos, o cliente e o auditado são a mesma figura, como pode ser exemplificado com a auditoria realizada por auditores da própria organização auditada, visando identificar, prevenir e controlar eventuais problemas ambientais.

O auditor-líder pode ser registrado em um organismo de certificação de auditores ambientais, se o cliente ou a lei assim o exigir. O credenciamento, em geral, apenas confere credibilidade adicional. 
A Norma ISO 14012 estabelece diretrizes para auditoria ambiental e critérios de qualificação para auditores ambientais. Um dos dispositivos da norma é a aceitação de auditores que tenham somente educação em nível médio de segundo grau. No Brasil, este critério não é aplicável. O Sistema Brasileiro de Certificação Ambiental determina, através das normas do INMETRO, que os auditores devem ter escolaridade correspondente à formação universitária. E no que concerne à experiência profissional, o auditor deve ter conhecimentos e habilidades em aspectos técnicos e ambientais das operações das instalações; em ciência e tecnologia ambiental; em legislação ambiental; em sistemas e normas de gestão ambiental; e em processos e técnicas de auditoria (ALMEIDA 2000).

A Resolução CONAMA n ${ }^{\circ}$ 319, publicada em 18 de agosto de 2003, estabelece os requisitos mínimos quanto ao credenciamento, registro, certificação, qualificação, habilitação, experiência e treinamento profissional de auditores ambientais para a realização das auditorias de sistemas de gestão e controle ambiental nos portos organizados, instalações portuárias, plataformas e suas instalações de apoio, dutos e refinarias. Todas as auditorias determinadas pela Resolução CONAMA n 306/02 deverão ser executadas por auditores ambientais que atendam aos critérios especificados na resolução acima indicada.

O Relatório de Auditoria Ambiental é de responsabilidade da equipe de auditores e deve conter a lista de pessoas contatadas durante a auditoria e respectivas atribuições, assim como as conclusões, incluindo constatações de conformidades e não conformidades; e a avaliação da capacidade da organização em assegurar a contínua adequação aos critérios estabelecidos.

Cabe aqui ressaltar que a responsabilidade civil ambiental é objetiva ou independente de culpa, conforme previsto no artigo 14 da Lei Federal $n^{\circ} 6.938 / 81$. A empresa não se isenta dessa responsabilidade pelo fato de submeter-se a uma auditoria. A empresa auditada, no entanto, poderá voltar-se regressivamente contra os auditores independentes que a tenham aconselhado com negligência, imperícia, imprudência e dolo. A responsabilidade dos auditores independentes será subjetiva 
ou com culpa, e, portanto, caberá à empresa auditada, neste caso autora da ação judicial, o ônus de provar a culpa. Porém, na auditoria ambiental privada, realizada por auditores internos, está presente o vínculo de subordinação e não há a possibilidade de ação regressiva contra estes.

A data de realização da auditoria in loco deve ser agendada entre os auditores e auditados. A equipe de auditoria elabora uma carta de confirmação da data previamente combinada, contendo ainda o objetivo, escopo e critérios a serem adotados e a envia ao agente responsável pela unidade auditada. Os funcionários desta unidade devem ter conhecimento da realização da auditoria, cabendo à empresa auditada disponibilizar documentos e facilidades necessárias ao desenvolvimento dos trabalhos.

\subsubsection{Itens essenciais à aplicação da auditoria ambiental}

É essencial para a efetiva aplicação da auditoria ambiental a definição clara, objetiva e documentada do seu objetivo e escopo, bem como a identificação dos envolvidos - cliente, equipe de auditores e auditados. De acordo com LA ROVERE (2000), a eficiência da execução de uma auditoria depende, pois, da existência de: recursos suficientes para suportar a auditoria; adequada informação a respeito do objeto de auditagem permitindo definir critérios claros para a auditoria; definição rigorosa e clara do escopo da auditoria; organização da auditoria onde são estabelecidos os critérios a serem nela usados e um plano de ação; cooperação por parte dos auditados; equipe de auditores independente e adequada à aplicação da auditoria ambiental.

A auditoria ambiental só deve ser aplicada quando todos os itens apresentados estiverem sendo cumpridos. Para que os resultados sejam consistentes é muito importante que as auditorias sigam padrões semelhantes de abrangência por meio da definição do escopo e de período a ser analisado na auditoria, e de procedimentos envolvendo metodologia aplicada e uso de instrumentos. 


\subsection{Auditoria Ambiental de Certificação ISO 14000}

Com a série ISO 14000, as normas ambientais transcendem as fronteiras nacionais e posicionam a gestão ambiental no mesmo patamar já alcançado pela gestão da qualidade. Cria-se, assim, mais um condicionante para o êxito da empresa que exporta e disputa sua posição em um mercado globalizado (BIANCHI 2002).

A conciliação das características ambientais dos produtos e serviços com os paradigmas da conservação e proteção ambiental é, cada vez mais, um requisito essencial para a competitividade das organizações e para estas manterem posições comerciais conquistadas com muito esforço. Por outro lado, as organizações que buscam na qualidade ambiental um fator de sucesso para se posicionar bem no mercado que atuam encontram, nas normas da série ISO 14000, a oportunidade para se valorizar internacionalmente.

As normas ISO 14000 têm como principal característica a voluntariedade e não estabelecem limites próprios para medição da poluição, padronização de produtos, níveis de desempenho. São concebidas como um sistema orientado para aprimorar o desempenho da organização por intermédio da melhoria contínua de sua gestão ambiental, sem a pretensão de impor índices e valores mínimos (VALLE 2002). 
Figura 2: Árvore ilustrativa da Norma ISO 14000.

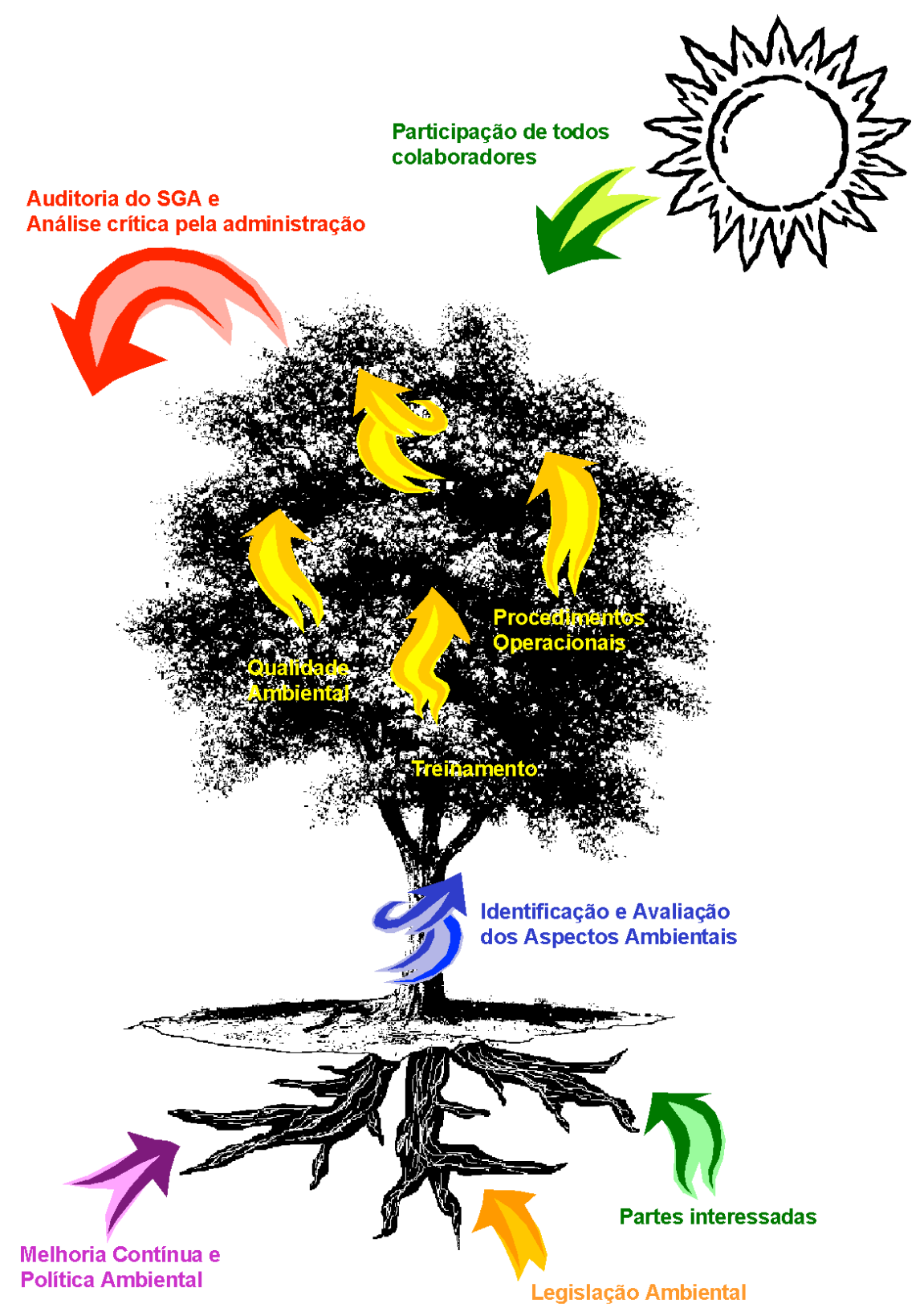

Fonte: Material cedido e utilizado pela empresa objeto de estudo.

\subsubsection{O surgimento das normas ambientais internacionais}

A International Standardization Organization - ISO é uma organização nãogovernamental, fundada em 23 de fevereiro de 1947, que congrega mais de 100 países, representando cerca de $95 \%$ da produção industrial do mundo. A organização é uma federação de caráter internacional, sediada na Suíça, e tem como objetivo 
principal facilitar o intercâmbio eficiente de mercadorias e serviços. A ISO é responsável pela elaboração de normas de aplicação internacional, mostrando consenso global e interesse comum. Todas as normas desenvolvidas pela ISO são de adoção voluntária (BUREAU VERITAS 1998).

A utilização maciça das normas de qualidade da Série ISO 9000 nas relações comerciais internacionais causa um impacto que não deixa dúvidas da necessidade das empresas se adaptarem aos novos tempos. Publicada em 1987, a Série ISO 9000 conta até 2003 com cerca de 561.700 empresas certificadas em todo o mundo*. O rápido crescimento do número de empresas certificadas mostra o grau de importância da implantação de procedimentos gerenciais que garantam a qualidade através de normas técnicas internacionais voluntárias.

Apesar de abordagens diferentes, as normas técnicas de sistemas de gestão ambiental compartilham dos mesmos princípios dos sistemas de gestão de qualidade. Antes mesmo de pronta, a Série ISO 14000, referente a sistemas de gestão ambiental, já acompanhava a tendência da Série ISO 9000, passando a se tornar importante exigência de mercado, principalmente para a exportação de produtos de elevado potencial poluidor destinados aos países desenvolvidos.

A despeito de ser voluntária, a certificação das empresas através destas normas torna-se importante para aquelas que desejam manter sua parcela de mercado. De maneira diversa das leis e regulamentos técnicos ambientais, que são compulsórios e seu não cumprimento passível de penalidade, estas normas são voluntárias e sua inobservância não acarreta sanções legais. No caso da norma ambiental voluntária, portanto, é o mercado que dita as regras, muitas vezes fechando as portas a regiões de grande interesse econômico àqueles que não adotam essas normas (LA ROVERE 2000).

O desenvolvimento das normas de sistemas de gestão ambiental para serviços, processos e produtos associa dois movimentos de extrema importância nos anos 90. O primeiro relaciona-se à grande disseminação dos sistemas de gestão da

* Disponível em <URL:http://www.iso.ch/iso/en/iso9000-14000/pdf/survey12thcycle.pdf> [2003 ago 20]. 
qualidade e de conceitos de controle e qualidade total. Se a empresa implementa um sistema de qualidade, facilita a introdução de um sistema de gestão ambiental, porque as normas das Séries ISO 9000 e 14000 têm estruturas bastante similares. Cabe ressaltar, inclusive, que a NBR ISO 14001 apresenta um anexo indicando a correspondência entre alguns de seus requisitos e os da ISO 9001. O segundo movimento dispõe sobre o crescimento do interesse das ONG's, das agências governamentais e dos partidos políticos em torno das questões ambientais. A união destes dois movimentos aumenta as pressões sobre as atividades produtivas que, por sua vez, organizam-se com objetivo de manter seu crescimento mediante a adoção de medidas que viabilizem a obtenção e manutenção de uma qualidade ambiental que permita vida saudável no presente e no futuro.

A proteção do meio ambiente passa a ser uma qualidade desejada do produto e a certificação ambiental torna-se instrumento para a obtenção de garantia da qualidade deste produto.

\subsubsection{A participação brasileira na elaboração da Série ISO 14000}

A Conferência das Nações Unidas sobre o Meio Ambiente e o Desenvolvimento - RIO 92, realizada em junho de 1992, no Rio de Janeiro, gerou impulso decisivo para o movimento de normalização ambiental internacional.

O Brasil, membro fundador da ISO, é representado junto a esta através da Associação Brasileira de Normas Técnicas (ABNT), uma sociedade privada, sem fins lucrativos, fundada em 1940, que corresponde ao Fórum Nacional de Normalização e promove a elaboração de normas em diversos domínios de atividades, além de efetuar a certificação de produtos e sistemas. A ABNT é membro "P”, com direito a voto no fórum internacional de normalização e, no Brasil, está credenciada pelo INMETRO desde 1997 como organismo certificador.

O Instituto Nacional de Metrologia, Normalização e Qualidade Industrial INMETRO, é uma autarquia federal, vinculada ao Ministério do Desenvolvimento, 
Indústria e Comércio Exterior, que atua como Secretaria Executiva do Conselho Nacional de Metrologia, Normalização e Qualidade Industrial - CONMETRO, colegiado interministerial, que é o órgão normativo do Sistema Nacional de Metrologia, Normalização e Qualidade Industrial - SINMETRO. Integrando uma estrutura sistêmica articulada, o SINMETRO, o CONMETRO e o INMETRO foram criados pela Lei Federal n. ${ }^{\circ}$ 5.966, de 11 de dezembro de 1973, cabendo a este último ampliar significativamente o seu raio de atuação a serviço da sociedade brasileira (BIANCHI 2002).

No âmbito de sua ampla missão institucional, o INMETRO objetiva fortalecer as empresas nacionais, aumentando sua produtividade por meio da adoção de mecanismos destinados à melhoria da qualidade de produtos e serviços. Sua missão é promover a qualidade de vida do cidadão e a competitividade da economia através da metrologia e da qualidade, recomendando ao Comitê Brasileiro de Certificação CBC, os procedimentos, critérios e regulamentos que serão utilizados para o credenciamento de organismos de certificação de gestão ambiental, para credenciamento e registro de auditores ambientais e de cursos para auditores ambientais.

Os critérios e diretrizes para o credenciamento de auditores e de organismos de certificação de Sistemas de Gestão Ambiental são baseados nas diretrizes das normas afins da Série ISO 14000 e naquelas estabelecidas pelo INMETRO para auditores de qualidade e de meio ambiente. O mesmo ocorre com cursos a serem ministrados para formar auditores ambientais.

Além disso, luta para conquistar o reconhecimento internacional do Sistema Nacional de Metrologia e do Sistema Brasileiro de Credenciamento de Laboratórios, Organismos de Certificação e Inspeção ao mesmo tempo em que vem trabalhando para que o país ingresse competitivamente no mercado externo.

Já o CONMETRO atua através de comitês, entre eles os de Certificação, Credenciamento Laboratorial, Metrologia, Normalização, etc.. O Comitê de 
Certificação Ambiental é composto por 32 entidades, incluindo as não governamentais e é quem define os critérios a serem seguidos pelos organismos certificadores e para habilitação de profissionais que realizarão as auditorias (MOURA 2002). Os organismos envolvidos são:

- Organismo Credenciador - é o INMETRO que atua realizando a habilitação dos organismos certificadores e verifica o desempenho dos mesmos para decidir sobre a manutenção do seu credenciamento;

- Organismo Normalizador - ABNT, que é a representante do Brasil na ISO desde sua fundação;

- Organismos Certificadores - são organismos sem fins lucrativos que realizam as auditorias nas empresas, segundo os critérios estabelecidos pelo INMETRO, pela ABNT ou por normas internacionais. Emitem um certificado, quando verificam a conformidade das atividades da empresa com essas normas. Têm-se como exemplos: ABS-QE - Quality Evaluations Inc.; BSI Brasil - British Standards Institution; BVQI do Brasil - Bureau Veritas Quality International; DNV - Det Norske Veritas; Fundação Carlos Alberto Vanzolini; GLC - Germanischer Lloyd Certification; SGS ICS Certificadora Ltda.; Tecpar - Instituto de Tecnologia do Paraná.

\subsubsection{A Estrutura da Série ISO 14000}

Organizações de todos os tipos têm uma preocupação cada vez maior em atingir e demonstrar um desempenho ambiental correto, controlando o impacto de suas atividades, produtos ou serviços no meio ambiente, levando em consideração sua política e seus objetivos ambientais. Esse comportamento se insere no contexto de uma legislação cada vez mais exigente, elaboração de políticas econômicas e de outras medidas destinadas a estimular a proteção ao meio ambiente e de uma crescente preocupação das partes interessadas em relação às questões ambientais e ao desenvolvimento sustentável . 
Muitas organizações realizam análises ou auditorias ambientais com o objetivo de avaliar seu desempenho ambiental. No entanto, por si só, tais análises e auditorias não garantem a uma organização que seu desempenho atenda, e continuará a atender, aos requisitos legais e à sua própria política. Para que sejam eficazes, há a necessidade de que esses procedimentos sejam conduzidos dentro de um sistema de gestão estruturado e integrado ao conjunto das atividades da empresa.

As normas internacionais de gestão ambiental visam prover às organizações os elementos de um sistema de gestão ambiental eficaz, passível de integração com outros requisitos de gestão, de maneira a auxiliá-las a alcançar seus objetivos ambientais e econômicos. Essas normas, como outras normas internacionais, não foram elaboradas para criar barreiras comerciais não-tarifárias, nem para ampliar ou alterar as obrigações legais de uma organização (ABNT 1996).

A série ISO 14000 tem como objetivo principal a implantação de um sistema de gestão ambiental que contribua para a organização cumprir os compromissos assumidos em prol do meio ambiente. E como objetivos decorrentes, as normas criam sistemas de certificação, tanto das organizações como de seus produtos e serviços, que dão a possibilidade de distinguir as empresas que atendem à legislação ambiental e cumprem os princípios do desenvolvimento sustentável.

Essa série de normas não substitui a legislação ambiental vigente no local onde está situada a organização. $\mathrm{Na}$ realidade, a reforçam, ao exigirem o cumprimento integral da legislação local, para que seja concedida a certificação. As normas também não determinam padrões de desempenho. Estes deverão ser determinados pela própria organização, dentro dos limites compatíveis com sua política ambiental (VALLE 2002).

Com a função de harmonizar os padrões de gestão ambiental, a ISO instalou, em 1993, um comitê denominado TC 207, com o objetivo de elaborar as normas da série ISO 14000. O TC 207 dividiu-se em seis subcomitês internacionais e um grupo 
de trabalho, que, por sua vez, são agrupados em duas categorias principais e uma categoria geral, conforme segue (BUREAU VERITAS 1998):

Das organizações

- SC1 - Sistema de Gestão Ambiental (EMS), presidido pela Grã-bretanha, é responsável pelas normas de gerenciamento ambiental, análoga à série ISO 9000, porém com abordagem mais abrangente, incluindo o cumprimento da legislação ambiental aplicável, plano de emergência, compromisso com a melhoria contínua, dentre outros;

- SC2 - Auditoria Ambiental e Investigações Correlatas (EA), presidido pela Holanda, responsável pelas normas de procedimentos dos vários tipos de auditoria e de qualificação dos auditores;

- SC4 - Avaliação de Desempenho Ambiental ou de Performance (EPE), presidido pelos EUA, responsável pela elaboração das normas para avaliar o desempenho das organizações em função do gerenciamento proposto, relacionando os riscos ambientais e impactos significativos.

Dos produtos

- SC3 - Rotulagem Ambiental (EL), presidido pela Austrália, é responsável pela normalização dos vários tipos de selo verde e etiquetas de autodeclaração;

- SC5 - Análise do Ciclo de Vida $(L C A)$, presidido pela França, é responsável pela elaboração de normas que orientam o impacto ambiental do produto, o inventário, melhorias do ciclo de vida do produto. O conceito básico é avaliar o impacto ambiental do produto, desde a extração da matéria-prima, elaboração do produto até sua utilização e disposição final adequada;

- WG - Working Group, ligado à direção do comitê, presidido pela Alemanha, responsável pela elaboração de um guia sobre a inclusão de aspectos ambientais em normas de produtos. 
Geral

- SC6 - Termos e Definições, presidido pela Noruega, é responsável pela harmonização de toda a terminologia utilizada nas normas do TC 207, abrangendo todos os subcomitês.

Hoje ainda existem os subcomitês SC7 - Projetos para o ambiente e SC8 Comunicação ambiental.

A ISO oficializou, em 1996, com base na norma da British Standard Institute, a BS 7750, as primeiras normas da série ISO 14000, direcionadas à implementação de sistema de gestão ambiental em atividades econômicas que possam afetar o meio ambiente, e para a avaliação e certificação destes sistemas com metodologias uniformes e aceitas internacionalmente (DONAIRE 1999).

A única norma dessa série que é objeto de certificação é a NBR ISO 14001, que dispõe sobre o SGA das organizações. Em setembro de 2003, o número de empresas certificadas com ISO 14001 em todo o mundo totaliza 49.462*, sendo 1000 empresas no Brasil (Revista Meio Ambiente Industrial 2003), conforme Anexo 7.

A relação das normas da Série ISO 14000 está apresentada no quadro a seguir:

Tabela 2: Quadro demonstrativo da Série ISO 14000.

\begin{tabular}{|ll|}
\hline \multicolumn{1}{|c|}{ SÉRIE ISO 14.000 } \\
\hline 14.000 & Guia Geral \\
14.001 & SGA - Especificações e diretrizes para uso (NBR desde 10/96) \\
14.004 & Sistemas de Gestão Ambiental (SGA) - Diretrizes Gerais (NBR desde 10/96) \\
14.010 & Diretrizes para Auditoria Ambiental - Princípios Gerais de Auditoria Ambiental \\
& (NBR desde 11/98) \\
$14.011-1$ & Diretrizes para Auditoria Ambiental e Procedimentos para Auditoria - Parte 1: Princípios \\
&
\end{tabular}

* Disponível em <URL:http://www.iso.ch/iso/en/iso9000-14000/pdf/survey12thcycle.pdf> [2003 ago 20]. 


\begin{tabular}{|c|c|}
\hline $14.011-2$ & Diretrizes para Auditoria Ambiental - Parte 2: Auditoria de Cumprimento de Legislação \\
\hline 14.012 & $\begin{array}{c}\text { Diretrizes para Auditoria Ambiental - Critérios de Qualificação de Auditores } \\
\text { (NBR desde 11/96) }\end{array}$ \\
\hline 14.014 & Diretrizes para a Realização das Revisões Prévias (diagnósticos) \\
\hline 14.015 & Diretrizes para Avaliações Ambientais de localidades e organizações \\
\hline 14.020 & Rótulos e Declarações Ambientais - Princípios básicos (NBR desde 06/02) \\
\hline 14.021 & Rótulos e Declarações Ambientais - Auto-declarações Ambientais (rotulagem tipo II) \\
\hline 14.024 & Rótulos e Declarações Ambientais - Princípios e Procedimentos (rotulagem tipo I) \\
\hline 14.025 & Rótulos e Declarações Ambientais - Princípios e Procedimentos (rotulagem tipo III) \\
\hline 14.031 & Gestão Ambiental - Avaliação do Desempenho Ambiental - Diretrizes \\
\hline 14.032 & Gestão Ambiental - Exemplos de avaliação do desempenho ambiental (ADA) \\
\hline 14.040 & $\begin{array}{l}\text { Gestão Ambiental - Avaliação do Ciclo de Vida - Princípios e Estrutura } \\
\text { (NBR desde 11/01) }\end{array}$ \\
\hline 14.041 & $\begin{array}{c}\text { Gestão Ambiental - Avaliação do Ciclo de Vida - Definição de escopo e análise do } \\
\text { inventário }\end{array}$ \\
\hline 14.042 & Gestão Ambiental - Avaliação do Ciclo de Vida - Avaliação do impacto do ciclo de vida \\
\hline 14.043 & Gestão Ambiental - Avaliação do Ciclo de Vida - Interpretação do ciclo de vida \\
\hline 14.047 & $\begin{array}{l}\text { Gestão Ambiental - Avaliação do Ciclo de Vida - Exemplos para a aplicação da ISO } \\
\qquad 14.042\end{array}$ \\
\hline 14.048 & Gestão Ambiental - Avaliação do Ciclo de Vida - Formato da apresentação de dados \\
\hline 14.049 & $\begin{array}{l}\text { Gestão Ambiental - Avaliação do Ciclo de Vida - Exemplos de aplicação da ISO } 14.041 \\
\text { para definição de objetivos e escopo e análise de } \\
\text { inventário }\end{array}$ \\
\hline 14.050 & Gestão Ambiental - Termos e Definições \\
\hline Guide 64 & Guia para inclusão de aspectos ambientais em normas de produto (NBR desde $05 / 02$ ) \\
\hline 14.062 & $\begin{array}{c}\text { Gestão Ambiental - Considerações de aspectos ambientais no desenvolvimento do } \\
\text { produto }\end{array}$ \\
\hline 14.063 & Gestão Ambiental - Comunicação ambiental - guias e exemplos \\
\hline Guide 66 & $\begin{array}{c}\text { Requisitos gerais para organismos de avaliação e certificação/ registro de sistemas de } \\
\text { gestão ambiental (NBR desde 12/01) }\end{array}$ \\
\hline 14.070 & Diretrizes para o Estabelecimento de Impostos Ambientais \\
\hline
\end{tabular}

Fonte: Pesquisa da autora. 


\subsubsection{Norma Brasileira ISO 14001}

O sistema de normas ISO 14000 tem como mérito a uniformização das práticas e dos procedimentos necessários para uma organização certificar-se ambientalmente, cumprindo um roteiro-padrão de exigências válido internacionalmente. Até 2003, a norma deste sistema que orienta as organizações para se certificarem ambientalmente é a ISO 14001, denominada Sistemas de Gestão Ambiental - Especificação e Diretrizes para Uso. Para que esse certificado seja reconhecido internacionalmente é necessário, contudo, que o procedimento de certificação seja realizado por uma auditoria de terceira parte, ou seja, por uma entidade especializada e independente, reconhecida por organismo autorizado de credenciamento.

A certificação é feita por auditorias independentes, com base em avaliação detalhada, que pode se estender por anos, e compromissos, por parte da empresa, de se adequar às exigências da legislação e de melhorar continuamente o desempenho de sua política ambiental.

A certificação ambiental traz benefícios, especialmente, para as organizações que têm obrigação de comprovar a adequação de seus processos produtivos e produtos aos novos paradigmas ambientais, cumprindo diferentes exigências em cada país para onde exportam. De acordo com VALLE (1995), a conformidade de uma organização com uma norma reconhecida internacionalmente, como a ISO 14001, tende a reduzir o número de auditorias ambientais independentes exigidas, seja por clientes, agências de proteção ambiental ou organismos de certificação.

Para uma organização alcançar a certificação ambiental, existem três exigências básicas expressas na norma ISO 14001 que precisam ser cumpridas:

ter um Sistema de Gestão Ambiental implantado;

cumprir a legislação ambiental aplicável ao local da instalação;

assumir um compromisso com a melhoria contínua de seu desempenho ambiental. 
A primeira fase é aquela em que a organização elabora sua Política Ambiental, que é uma declaração da empresa, apresentando suas intenções, seus compromissos e os princípios gerenciais em relação ao seu desempenho ambiental. Ao mesmo tempo, definem-se os objetivos, as metas da empresa e os procedimentos a serem seguidos por seus funcionários. Esta fase pode ser denominada fase preparatória e ainda inclui o início do treinamento do pessoal e a criação dos procedimentos de controle da documentação.

A segunda fase envolve a identificação dos aspectos ambientais e respectivos impactos no meio ambiente, decorrentes dos processos produtivos e dos serviços da empresa. É possível identificar os pontos vulneráveis existentes nos procedimentos ambientais da empresa, e, assim, poder encaminhar sua correção. Esta segunda fase é denominada de pré-auditoria ou diagnóstico. As empresas que já tinham preocupação e consciência ambiental têm mais facilidade em se adequar à norma e poderão alcançar, num prazo menor, a almejada certificação.

Já a terceira fase é a da certificação propriamente dita. Deve-se contratar uma entidade credenciada para emitir o correspondente certificado de conformidade com a norma ISO 14001. Neste momento, a empresa se submete a uma auditoria ambiental, que comprova sua conformidade com os padrões de qualidade exigidos pela legislação ambiental vigente e pelos manuais de qualidade instituídos e utilizados pela própria empresa.

A norma ISO 14001 foi redigida de forma a aplicar-se a todos os tipos e portes de organizações e para adequar-se a diferentes condições geográficas, culturais e sociais.

Segundo VALLE, 2002, a adesão à norma ISO 14001 não exige, como prérequisito, a certificação pelas normas da série ISO 9000 e vice-versa. Eles são sistemas independentes, embora a adesão a ambos gere economias de escala quanto à documentação e à prática das auditorias periódicas que ambos os sistemas exigem. 
O Sistema de Gestão Ambiental (SGA) preconizado pela norma ISO 14001 tem sua estrutura baseada no ciclo de melhoria contínua, conhecido por PDCA Plan, Do, Check, Act, com o significado dos verbos planejar, executar, verificar e corrigir em inglês.

\section{Figura 3: Ciclo PDCA}

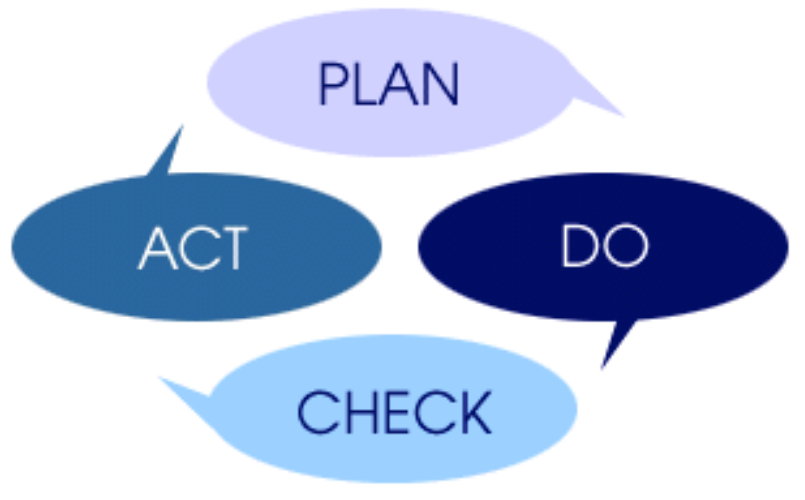

Fonte: [USEPA]

O sucesso do sistema depende do comprometimento de todos os níveis e funções da empresa, especialmente da alta administração. Um sistema deste tipo permite a uma organização estabelecer e avaliar a eficácia dos procedimentos destinados a definir a política e os objetivos ambientais; atingir a conformidade com eles e demonstrá-los a terceiros. A finalidade da norma ISO 14001 é equilibrar a proteção ambiental e a prevenção da poluição com as necessidades socioeconômicas. É importante observar que os requisitos especificados em um SGA podem ser abordados simultaneamente ou reapreciados a qualquer momento.

A gestão ambiental não é um tema que interessa somente aos especialistas ou responsáveis pela área ambiental da empresa. Assim como já se observava com a gestão da qualidade, é um tema que, por sua importância e destaque, desperta o interesse de toda a empresa, desde seus técnicos e pesquisadores, responsáveis pelo desenvolvimento de novos produtos, passando pelos setores jurídicos e financeiros, até os níveis de direção, abrangendo, assim, todo o organograma da empresa. 
Quando a empresa se organiza para obter a certificação ambiental, o simples cumprimento da lei para evitar as sanções impostas pelos órgãos ambientais não é mais suficiente. A necessidade de garantir a competitividade da empresa em mercados cada vez mais dinâmicos e exigentes tem levado o empresário consciente a adotar atitudes mais objetivas e responsáveis com relação ao tema ambiental. A transparência de sua imagem diante do cliente-usuário e da sociedade em geral tem grande peso nesse processo. A boa imagem ambiental da empresa, que é assegurada pela certificação, se transforma em um poderoso elemento de marketing na venda de seus produtos e serviços (VALLE 2002).

Por outro lado, algumas empresas fazem má utilização de sua certificação através de propaganda enganosa, distorcendo o seu significado. No caso dos sistemas certificados pela ISO 14001, a certificação garante que há um sistema de gestão ambiental funcionando, que atende aos padrões da norma, porém não garante o desempenho ambiental excelente da empresa e sim, apenas, um compromisso com a melhoria contínua. Também não é garantia de cumprimento integral da legislação, apenas o comprometimento da empresa em obedecê-la.

Entre os benefícios geralmente apontados pelas empresas certificadas está a melhoria de sua imagem junto ao mercado. Atualmente, no Brasil, essa melhoria de imagem tem trazido questionamentos devido a vários acidentes ocorridos com algumas empresas que têm diversas unidades certificadas pela ISO 14001, e utilizam essa certificação em suas propagandas corporativas (PHILIPPI JR \& AGUIAR 2003).

De outra parte, os empresários podem ser agradavelmente surpreendidos quando a reavaliação das condições de produção e de seus impactos sobre o meio ambiente - necessária para obter a certificação ambiental, pode contribuir para a ampliação das vantagens competitivas da empresa, reduzindo custos de seus produtos e serviços. Um sistema de gestão ambiental bem estruturado, nos moldes do que preconiza a norma ISO 14001, permite reduzir custos operacionais e financeiros. Esse sistema também contribui para reduções sensíveis na geração de resíduos, daí 
resultando um melhor controle dos impactos ambientais causados pelas atividades da empresa. Os benefícios alcançados com a destinação final adequada dos resíduos gerados e a eliminação de eventuais multas e penalizações causadas por uma má gestão ambiental podem ser expressivos, mesmo em curto prazo.

Acrescente-se aos pontos positivos previamente expostos, a real possibilidade de serem aplicados prêmios de seguros mais baixos às empresas certificadas, por estarem menos sujeitas a riscos. Da mesma forma, VALLE (2002) dispõe que as taxas de juros preferenciais podem ser aplicadas aos empréstimos concedidos por organismos financeiros que avaliam os riscos ambientais de seus clientes.

Toda empresa que adotar essa nova abordagem sistêmica e pró-ativa, buscando a obtenção de sua certificação ambiental, estará atingindo, dessa forma, a ecoeficiência (grifo nosso). A ecoeficiência combina desempenho econômico e ambiental. Permite que processos produtivos possam ser mais eficientes, refletindo em novos e melhores produtos e serviços, com menor utilização de recursos naturais e menos poluição em todo o ciclo de vida. A ecoeficiência permite maximizar ganhos para as empresas e a sociedade através da promoção dos princípios do desenvolvimento sustentável.

Por fim, deve ficar muito claro que a certificação ambiental deverá ser sempre conseqüência e não causa para a implantação e consolidação de um sistema de gestão ambiental na empresa (VILHENA \& POLITI 2000).

Com toda esta evolução da questão ambiental; da legislação ambiental e da implementação de sistemas de gestão ambiental, torna-se importante estudar avanços e resultados que vem sendo obtidos com as suas aplicações, e justifica-se o desenvolvimento do presente trabalho. 


\section{OBJETIVOS}

\subsection{Objetivo Geral}

Avaliar o processo da certificação ISO 14001 em uma empresa do setor automotivo.

\subsection{Objetivos Específicos}

- Caracterizar a empresa;

- Identificar pessoas envolvidas no processo;

- Descrever as diferentes fases do processo de certificação;

- Avaliar o grau de conhecimento e envolvimento dos entrevistados com relação ao processo (implantação, implementação, certificação e póscertificação) e em relação à atual legislação ambiental brasileira. 


\section{METODOLOGIA}

\subsection{Delineamento do Estudo}

O presente trabalho constituiu um estudo de caso, com uma abordagem metodológica descritiva, quantitativa e qualitativamente.

\subsection{Local de Estudo}

Foi consultada a Edição Especial da Revista Meio Ambiente Industrial (2002), e, a partir da análise dos artigos nela contidos, elaborou-se uma consolidação das informações sobre 51 (cinqüenta e uma) empresas certificadas em conformidade com a Norma ISO 14001, por estado de origem. Ainda fizeram parte da consolidação a descrição dos motivos, procedimentos, investimentos, organismos certificadores e os benefícios obtidos com a certificação para cada uma dessas empresas (Anexo 1).

Também foi realizado um levantamento das indústrias certificadas em conformidade com a Norma ISO 14001 junto à CIESP/FIESP, ao INMETRO, à Secretaria do Meio Ambiente e à Agência de Proteção Ambiental do Estado de São Paulo.

De posse dessas informações, elaborou-se os critérios para seleção da empresa que se constituiria no presente estudo de caso. Os critérios foram:

- empresa certificada em conformidade com a Norma ISO 14001;

- com Sistema de Gestão Ambiental implementado e em funcionamento;

- líder na área de meio ambiente em nível mundial;

- apontada como benchmarking;

- comprometida com as questões do meio ambiente;

- investidora em projetos ambientais;

- reconhecida nacional e internacionalmente; 
- com participação junto às comunidades do entorno no exercício da cidadania corporativa;

- que concordasse e permitisse a realização do estudo, dando condições de acesso às informações necessárias.

A empresa que preencheu todos os requisitos foi uma multinacional do setor automotivo, localizada no Município de São Bernardo do Campo, Estado de São Paulo.

A metodologia também foi observacional, pois foi realizada uma Visita Técnica monitorada à empresa para possibilitar um melhor conhecimento da planta física e funcionamento da mesma.

\subsection{População de Estudo}

Para definição das pessoas a serem entrevistadas, foram estabelecidos contatos com a diretoria da empresa selecionada, assim como com o setor responsável pela área ambiental.

Definiu-se, de comum acordo (empresa - pesquisador), que seriam entrevistados os responsáveis pela questão ambiental em cada setor da empresa, que participaram na fase de implementação (nove pessoas) e na fase pós-certificação (onze pessoas).

Convencionou-se também, de comum acordo, que deveriam ser entrevistados também os dois diretores diretamente responsáveis pela área ambiental e o assessor da Presidência, os quais tiveram participação ativa desde o início do processo.

Todas as pessoas a serem entrevistadas foram identificadas e as entrevistas foram agendadas de acordo com suas disponibilidades. 
Para complementar, foram programadas entrevistas com os funcionários operacionais denominados "chão de fábrica". A abordagem pelo próprio pesquisador foi em um único dia, ao acaso, em horário de descanso, após almoço, no próprio pátio da empresa. Foi realizada uma única pergunta: "Você sabe o que é a Norma ISO 14001?". A resposta deveria ser sim ou não (Anexo 2).

\subsection{Instrumento para coleta de dados}

Foi desenvolvido um questionário constituído de quatorze questões e submetido a três pré-testes em populações semelhantes, para avaliar sua eficiência e "evidenciar possíveis falhas na redação do questionário, tais como: complexidade das questões, constrangimentos ao informante, tempo de entrevista” (GIL 1994).

Posteriormente, de acordo com os resultados do pré-teste, os ajustes necessários foram realizados para definir a versão final do questionário, com quinze questões (Anexo 3).

A entrevista foi organizada como uma forma de estabelecer um tipo de comunicação entre o pesquisador e o entrevistado, criando um clima propício para obtenção da resposta.

Ao mesmo tempo em que os questionários foram preenchidos pelo próprio pesquisador, as entrevistas eram gravadas com autorização dos entrevistados, para posterior transcrição e, se necessário, complementar as anotações.

\subsection{Análise dos resultados}

A análise dos dados foi feita utilizando o método de análise de conteúdo, no sentido que lhe é dado por Laurence Bardin (L 'Analyse de contenu, 1977), como um “conjunto de técnicas de análise das comunicações visando obter, por procedimentos 
sistemáticos e objetivos de descrição do conteúdo das mensagens, indicadores (quantitativos ou não) que permitam a interferência de conhecimentos relativos às condições de produção/recepção (variáveis inferidas) destas mensagens" (BARDIN 1995).

As três etapas propostas pelo método são: pré-análise, descrição analítica e interpretação inferencial. A pré-análise constituiu-se de uma leitura geral dos dados, no sentido de tomar conhecimento das respostas obtidas. Num segundo momento, tomando-se como base as referências teóricas, procedeu-se a uma descrição analítica do estudo. Dando seqüência, foi feita a codificação e categorização das variáveis, de acordo com as idéias coincidentes ou divergentes. A terceira etapa constituiu-se de uma reflexão, estabelecendo relações de caráter técnico e prático.

$\mathrm{Na}$ análise dos dados, além das técnicas de agrupamento de palavras e categorização do conteúdo das entrevistas, fez-se uso das informações obtidas nas observações reais. Visando a um maior enriquecimento do texto, foram destacados trechos de depoimentos dos respondentes, que tiveram relevância para a análise de cada tópico. Esses depoimentos foram transcritos sem modificações, sendo mantidas as palavras originais dos respondentes.

As questões foram quantificadas, apresentadas em tabelas e figuras. Foram utilizados os programas EpiData e Microsoft Excel.

Esses resultados propiciaram uma rica análise e discussão, e serão devolvidos à população de estudo, para conhecimento. 


\subsection{Aspectos Éticos}

A participação dos entrevistados nos estudos foi voluntária mediante termo de consentimento por escrito (Anexo 4), assegurando-se a apresentação de informações e objetivos sobre a pesquisa, a confidencialidade das informações e o retorno à empresa. O estudo foi aprovado pelo Comitê de Ética em Pesquisa da Faculdade de Saúde Pública da Universidade de São Paulo (Anexo 5) 
RESULTADOS 


\section{RESULTADOS}

A empresa possui um quadro com cerca de 10.000 funcionários e foi muito interessante conhecer os responsáveis pela questão ambiental de vinte e um setores da empresa, a assessoria da presidência e duas das diretorias. A visita a cada um desses setores e o conjunto de informações transmitidas pelos seus responsáveis, possibilitou formar uma visão geral de todos os setores envolvidos no processo de implementação do SGA.

As áreas envolvidas no presente trabalho foram:

Assessoria da Presidência - AP

Diretoria de Gestão da Qualidade - DGQ

Diretoria de Planejamento e Engenharia Industrial - DPI

Coordenação do Planejamento de Vendas e Assistência a Vendas - CPV

Centro Tecnológico da Qualidade de Materiais - CTQ

Documentação e Pagamento - DPR

Desenvolvimento da Rede de Concessionários - DRC

Recrutamento, Seleção e Programa de Jovens Talentos - DTR

Engenharia de Sistemas de Gestão da Qualidade e Meio Ambiente - EGQ

Estratégia, Procedimento e Resultado de Compras - EPC

Planejamento e Processos de Produção - Estamparia - EST

Engenharia de Valores de Planejamento Industrial - EVP

Fabricação de Chassis para Ônibus - FCO

Gerência de Engenharia de Infra-estrutura / Operação Ambiental - GEI 5

Planejamento de Produção de Eixos - GPE

Logística Power System - eixos e motores - LPS

Logística Central - LOC

Manutenção da Fabricação de Motores - MFM

Oficina de Preparação de Protótipos de Caminhões - OPP

Produção de Cabinas - PCA

Produção e Planejamento de Motores - PPM 
Tecnologia de Motores Pesados - TMP

Tecnologia de Projetos - TPO4

\subsection{População de Estudo}

\subsubsection{Seleção dos entrevistados}

Foram identificados e entrevistados 23 indivíduos envolvidos com a questão ambiental dos setores referidos. Em março de 1999, foi criado um Grupo denominado Multifuncional, constituído pelos líderes operacionais, que eram chamados para discutir metas e políticas da empresa. Cada líder teve um facilitador dentro de sua área, que foi o responsável pela atualização do banco de dados, dentre outras atividades.

Tanto os líderes operacionais como os facilitadores foram treinados para realizar o levantamento e gerenciamento de aspectos ambientais e implantação da ISO 14001 na empresa, tendo como função disseminar a questão ambiental dentro de cada área.

\subsubsection{Caracterização dos entrevistados}

Os resultados com relação à formação universitária (Figura 4) indicaram que vinte e dois entrevistados possuem curso superior completo, exceto um. Destes, $68,2 \%$ são formados em engenharia, compreendendo engenharia mecânica; de produção; de indústria; química; sanitária ambiental; elétrica e engenharia ambiental. As demais profissões referidas são administração (9,1\%); ciências contábeis (4,5\%); direito $(4,5 \%)$; publicidade $(4,5 \%)$ e tecnologia de produção $(9,1 \%)$.

Pode-se ressaltar que cinco dos entrevistados referiram ter realizado Cursos de Especialização em Administração Financeira, Direito Ambiental, Engenharia 
Ambiental, Engenharia de Segurança do Trabalho, Gestão Ambiental e Saneamento Ambiental.

Figura 4: Distribuição dos entrevistados segundo formação universitária

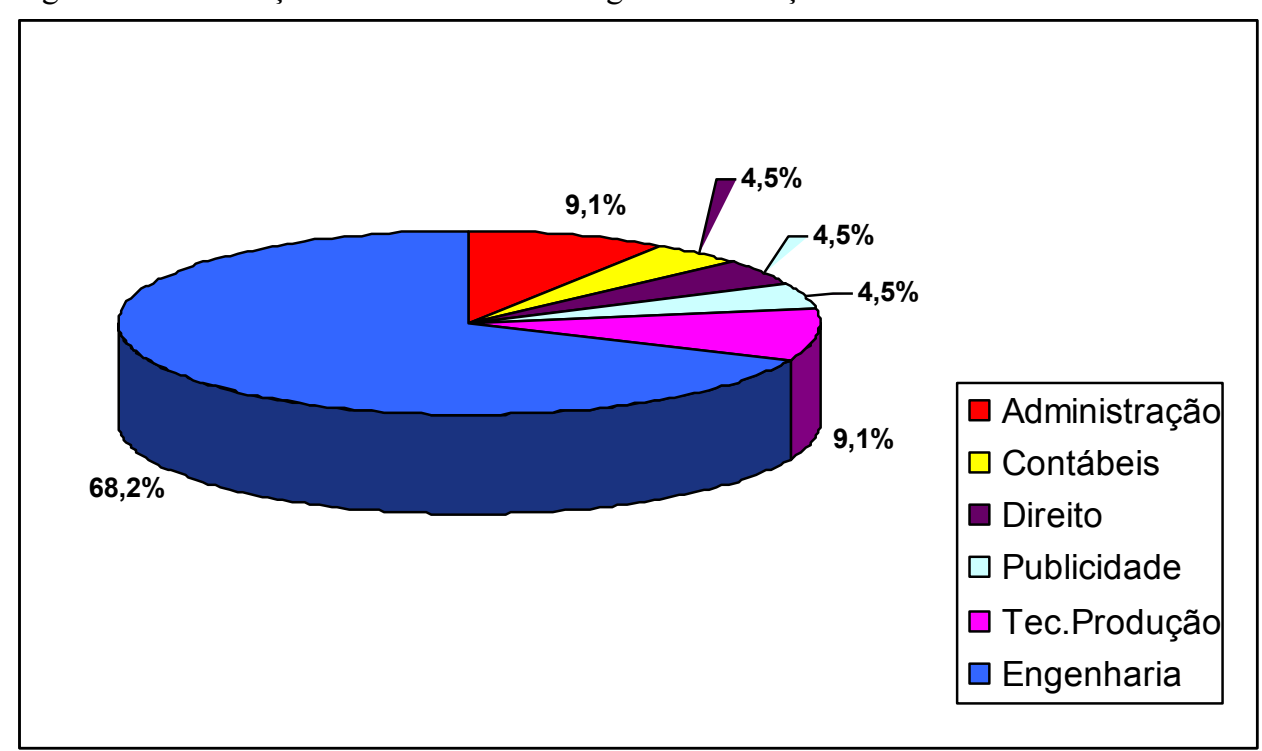

Os entrevistados são $87,0 \%$ do gênero masculino e apenas $13,0 \%$ do gênero feminino, conforme Figura 5.

Figura 5: Distribuição dos entrevistados segundo gênero

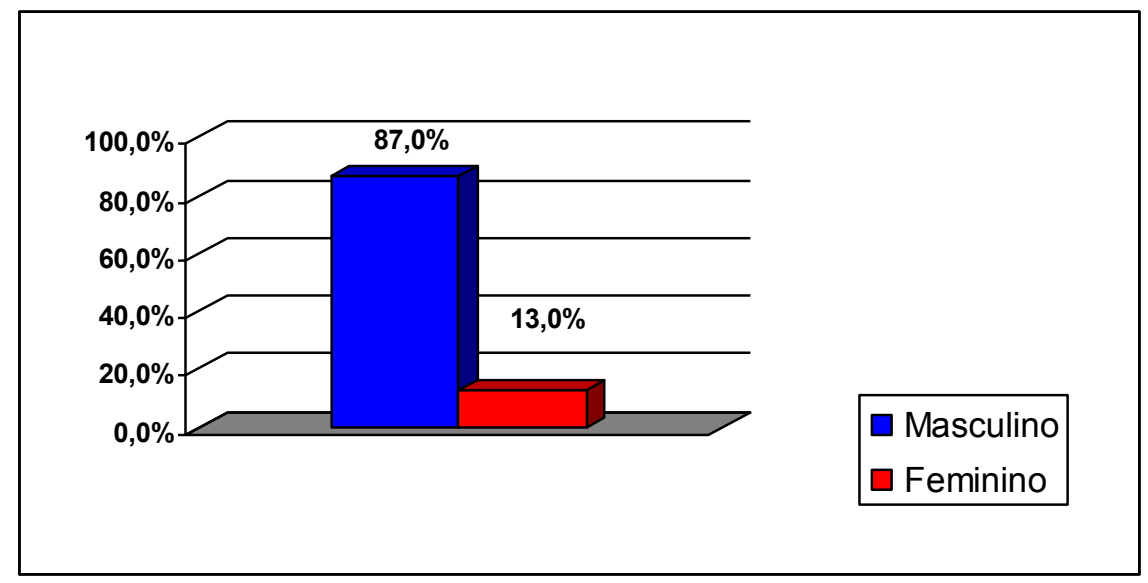

Ao se avaliar o tempo de trabalho na empresa, os entrevistados apresentaram as respostas conforme Figura 6, sendo 30,4\% $(n=7)$ com até cinco anos; 26,1\% $(n=6)$ com 6 a 15 anos; 21,7\% (n=5) com 16 a 20 anos; e 21,7\% $(n=5)$ com 20 anos ou mais. 
Figura 6: Tempo de empresa (anos) referido pelos entrevistados

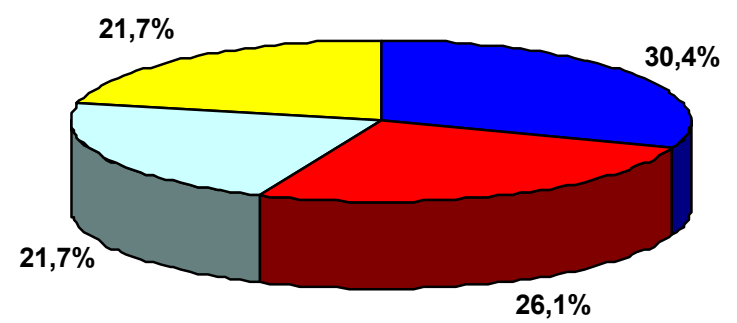

Até 5 anos

$\square$ De 6 a 15 anos

$\square$ De 16 a 20 anos

$\square$ Acima de 20 anos

Com relação aos entrevistados que atuam na área ambiental ou estão envolvidos com a questão ambiental (Figura 7), as respostas indicam que apenas $21,7 \%$ não atuam e nem tampouco têm envolvimento direto com a questão ambiental.

Figura 7: Freqüência de entrevistados que atuam na área ambiental

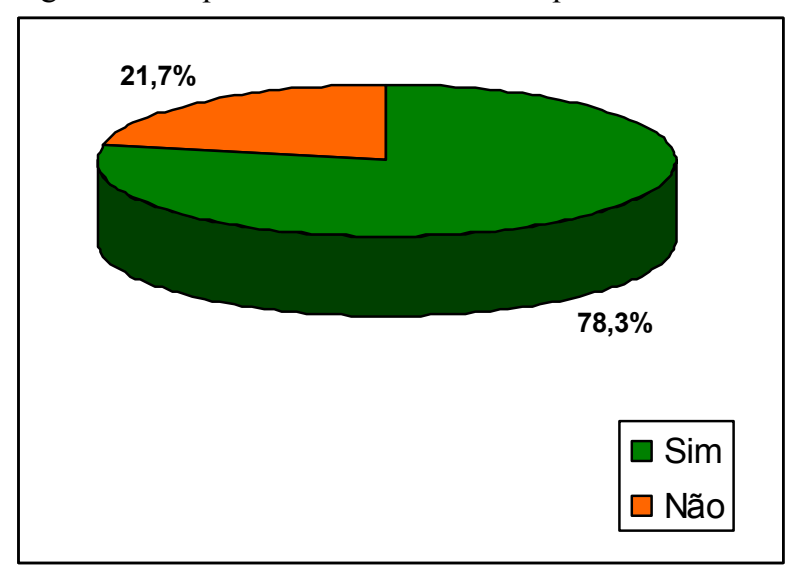

Ao se perguntar aos entrevistados sobre qual o motivo que levou a empresa a buscar a implementação da certificação em conformidade com a Norma ISO 14001, $43,5 \%$ responderam que era a preocupação e o comprometimento com o meio ambiente (Figura 8). 
Ao analisar os oito motivos expostos conforme a Figura 8, um dos entrevistados colocou que: "A preocupação ambiental e práticas voltadas para proteção do meio ambiente já faziam parte dos processos da empresa antes da decisão de implantar o SGA de acordo com a ISO 14001. Partiu-se, então, para uma sistematização das ações e conseqüentemente para a busca do certificado ISO 14001 ”. Esta colocação foi feita como motivo ligado ao Ambiente.

Figura 8: Motivos referidos pelos entrevistados para certificação

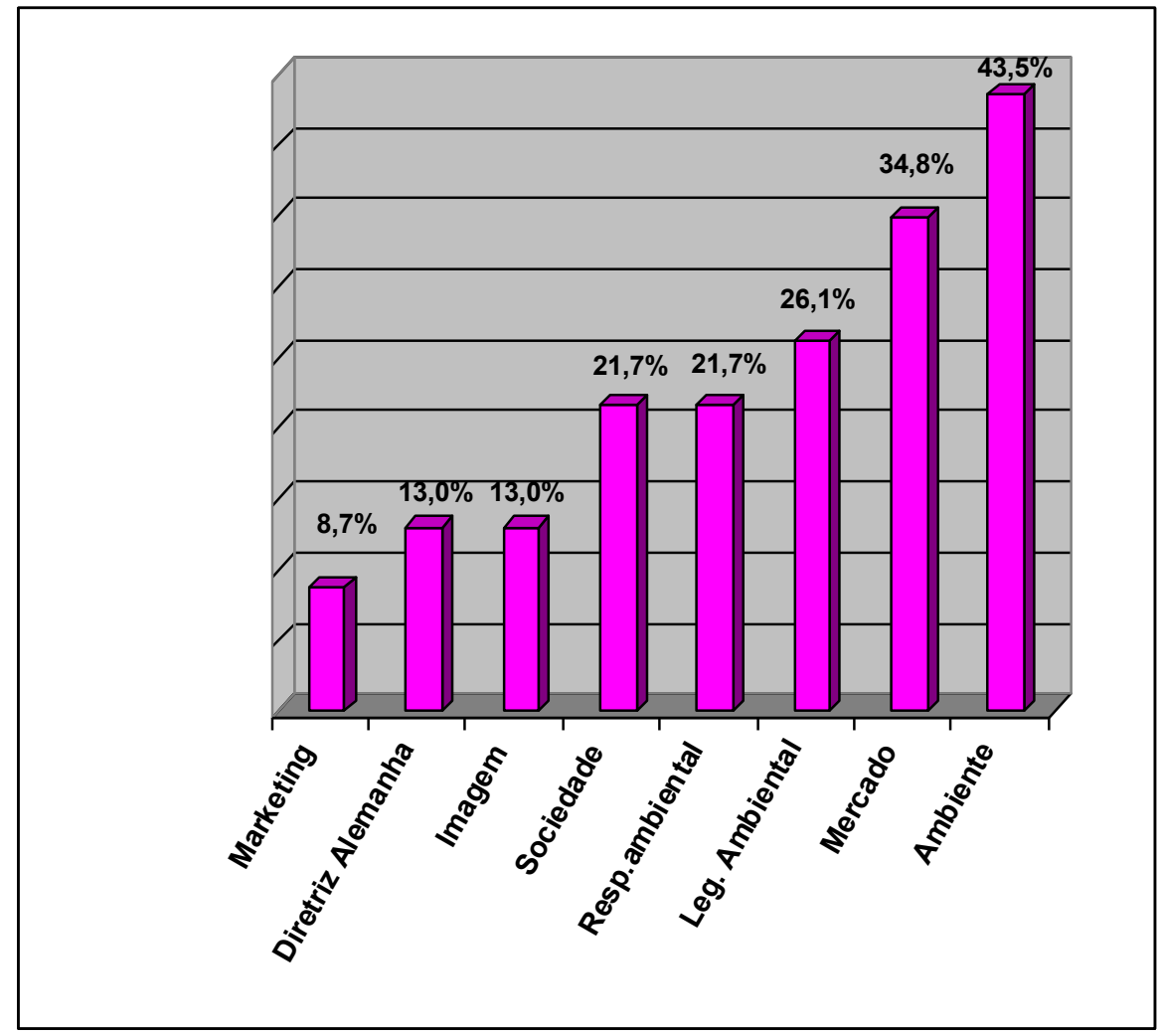

Para 34,8\% dos entrevistados, o que impulsionou a certificação foram as exigências de mercado, que passou a exigir produtos e serviços que levam em conta o aspecto ambiental e o controle sobre os impactos causados ao ambiente, adequando o cenário para melhor atender aos clientes, à comunidade, às demais partes interessadas e às futuras gerações.

$\mathrm{O}$ atendimento à legislação ambiental é outro motivo que contribuiu para a implementação da certificação, de acordo com a opinião de $26,1 \%$ dos entrevistados. Um exemplo poderia ser a resposta de um deles, conforme segue: 
"Solucionar pontos vulneráveis na empresa, especialmente quanto ao atendimento da legislação ambiental. O impacto desta legislação (especialmente a lei de crimes ambientais) nos negócios e aspectos financeiros é grande. A melhor forma de solucionar os problemas é ter um sistema de gestão em conformidade com a ISO”.

A responsabilidade ambiental e a responsabilidade social foram fatores propiciadores para a implementação do SGA e conseqüente certificação em conformidade com a ISO 14001 na opinião de 21,7\% dos entrevistados (Figura 8).

Tem-se como exemplo a opinião de um dos diretores da empresa:

"Primeiro, como uma necessidade de metodologia para nos organizarmos em termos de operação e estratégia ambiental. O segundo motivo é que, através dessa organização mais sistêmica, conseguimos uma sinergia e, conseqüentemente, um tempo menor na implantação de processos mais seguros dessa operação. Principalmente no enfoque ambiental, que tem ficado cada vez mais restrito. Em função da nossa responsabilidade social (grifo da autora), tínhamos que rapidamente fazer uma revisão dos nossos processos. A ISO 14001 se mostrou como uma ferramenta muito interessante para fazermos isso de uma forma organizada, rápida e com resultados monitorados e quase que garantidos".

Outras duas razões apresentadas pelos entrevistados para motivar uma empresa a buscar a certificação foram a imagem da empresa e o atendimento a uma exigência da matriz, com 13\% (Figura 8). Através das entrevistas pode-se constatar que a decisão veio da direção da empresa, mostrando seu comprometimento não só com o meio ambiente, mas, também, o respeito a seus colaboradores, clientes e comunidade vizinha.

Apenas $8,7 \%$ dos entrevistados apontaram o fator marketing da empresa como motivo para implementação. Os que justificaram dessa maneira dizem que faz diferença mostrar que é uma empresa responsável ambientalmente, proporcionando abertura de novos mercados. 
Vários entrevistados apresentaram respostas múltiplas para esta questão (Figura 8), apontando mais de um motivo, como, por exemplo, um dos diretores que assim se expressou:

"Desde antes da Eco-92, o tema ambiental já era uma herança da matriz. Os eventos acontecem antes na Europa e levam um certo tempo para serem reproduzidos aqui no Brasil. Foi a fase que a ciência descobriu e provou que certas substâncias químicas prejudicavam a saúde e degradavam o meio ambiente. Naquela época, a ciência mostrava os fatores prejudiciais de uma maneira geral. Mas foi a partir de 1998 que surgiu a idéia de implementar a ISO 14001. Já tínhamos a preocupação ambiental. Por quê? Por causa da responsabilidade social da empresa, para o desenvolvimento de produtos com uma maior utilização de matérias-primas renováveis, para evitar desperdício, gerando economia. E, também, para criar massa crítica para todos os funcionários".

Com relação aos resultados obtidos na questão que avalia o grau de conhecimento adquirido pelos colaboradores em treinamentos (Figura 9), constatouse a extensão e complexidade das respostas obtidas. Optou-se, então, por classificálas em grupos de respostas com conceitos, na seguinte escala: nenhum conhecimento; conhecimento fraco; conhecimento regular; conhecimento bom; e conhecimento ótimo.

Os resultados para esta questão foram:

- Nenhum conhecimento (13\%): os indivíduos que não participaram do processo e não souberam responder.

Exemplo:

"Não participei do processo. Já entrei quando o sistema estava implementado".

- Conhecimento fraco $(17,4 \%)$ : os indivíduos que foram contratados no meio do processo e somente citaram fases do processo e/ou aqueles que souberam relatar dados gerais.

Exemplo: 
"Quando comecei a trabalhar na empresa, o processo de implantação do SGA já havia começado. Já havia sido adotada a ISO 14001 como especificação para implantação, a consultoria já estava atuando, o levantamento de aspectos e impactos já havia sido feito e a Política Ambiental já havia sido criada”.

- Conhecimento regular (30,4\%): os indivíduos souberam descrever algumas fases do processo e sabiam dizer que havia sido contratada uma consultoria. Exemplos:

"O primeiro passo foi levantar os aspectos e impactos ambientais, a legislação aplicável. Depois foram determinados os procedimentos de cada área. Uma consultoria foi contratada para verificar o que tinha sido realizado e depois foi feita a auditoria de certificação em julho de 2001".

"Diretoria decidiu implementar e formou grupos de trabalho. Visando atender todos os requisitos da norma, fez o levantamento de aspectos e impactos ambientais e o mapeamento dos riscos".

- Conhecimento bom (26,1\%): os indivíduos que demonstraram ter participado efetivamente de todo o processo, pois conseguiram descrever as fases do processo e deram bastante ênfase aos treinamentos e processos de capacitação.

Exemplos:

"Foram formados grupos de trabalho, que elaboraram uma sistemática para implantação do sistema. A norma se aplica desde a área de vendas até a área de compras e produção. Cada procedimento tratou de um assunto. Criou-se uma supervisão de meio ambiente que reuniu os representantes de cada diretoria. Formou-se o Grupo Núcleo (cada diretoria deveria indicar um representante que seria o líder operacional) e havia reuniões semanais com o anúncio das diretrizes para a implantação do sistema. E esses líderes operacionais que seriam os responsáveis pela multiplicação das informações = Árvore de colaboradores". 
"Primeiro buscaram-se representantes das várias áreas, para quem foi explicado o que era e como se pretendia implantar o sistema de gestão ambiental. Segundo foi montado um grupo para implantar o sistema nas áreas, formando-se a política ambiental da empresa e o estabelecimento dos procedimentos operacionais (manual). Terceiro foi promovido o treinamento dos funcionários. Depois se realizaram as auditorias e envolvimento das pessoas no processo (o que se mostrou muito difícil por parecer uma preocupação secundária). Hoje as pessoas já estão mais conscientizadas. A certificação veio em 2001. Mas a incorporação da cultura de proteção ambiental nas pessoas ainda precisa ser feita".

"Convencimento. Cada vez que se fala na implantação de uma norma (tivemos isso também com a ISO 9001), a primeira reação da equipe é a de que estamos burocratizando um processo existente. O primeiro passo foi o de motivação da equipe, dos beneficios que teríamos em implantar a ISO 14001. Essa motivação foi necessária para a diretoria (porque tem um custo alto), e depois da equipe toda. Contratamos uma consultoria para nos ajudar no processo”.

- Conhecimento ótimo (13,0\%): os indivíduos que comprovaram, através de respostas completas e bem elaboradas, com detalhes e particularidades de cada fase, ter participado de todo o processo e incorporado os conceitos aprendidos.

Exemplos:

“O primeiro passo é definir o processo: a norma dá duas opções - ou olhar só para dentro da empresa ou adotar a sociedade como participante no processo. Nossa opção foi pela segunda. Levantamento de aspectos e impactos ambientais (ver o que está gerando de resíduo e que impacto tem); primeira filtragem é o atendimento à legislação. Foram averiguados os focos de geração de resíduos (local ou global). Grau de severidade: verificar quais são passíveis de monitoramento e adequação dos resíduos às exigências. Gerar procedimento operacional padrão. Por exemplo: forno com sensor medindo emissão de gás. Tá atendendo à legislação? Se não estiver, tenho que ver qual é a mistura de gases ideal para isso. Registro e licença de instalação e funcionamento das máquinas (desde 1976) junto à CETESB. Existe o 
monitoramento, os planos de ação integrada e o plano global. Identifiquei o resíduo - classifiquei ele - planos de ação: vou monitorar ou não vou? - como gerenciar? se tiver emergência, como resolver?

Há um banco de dados para controle de resíduos internos - da geração e do descarte. Atualização anual. Melhoria contínua. Atualização vai dizer se estou mudando algum processo, etc.. Desenvolvimento da política ambiental da empresa e compromisso com a comunidade”.

“Avaliação da empresa e contratação de uma consultoria especializada para definir a rota e traçar o diagnóstico ambiental. No diagnóstico, foram focados três aspectos: a conformidade legal, as tendências futuras da legislação e boas práticas. $O$ investimento total foi calculado em $R \$ 15$ milhões para implantar a certificação. No fim de 1998, a alta direção da empresa liberou a quantia para executar um processo ambiental, junto ao órgão ambiental, no que diz respeito aos passivos ambientais da empresa (como gerenciá-los). Neste momento, eliminamos todas as fontes de contaminação (por exemplo, chumbo e estanho). Definidas as ações, realizaram-se o levantamento de aspectos e impactos ambientais e uma análise crítica desses impactos sob três fatores: freqüência, abrangência e gravidade. Foi criado um banco de dados, que é constantemente atualizado por uma empresa terceirizada”.

Figura 9: Grau de conhecimento adquirido pelos entrevistados

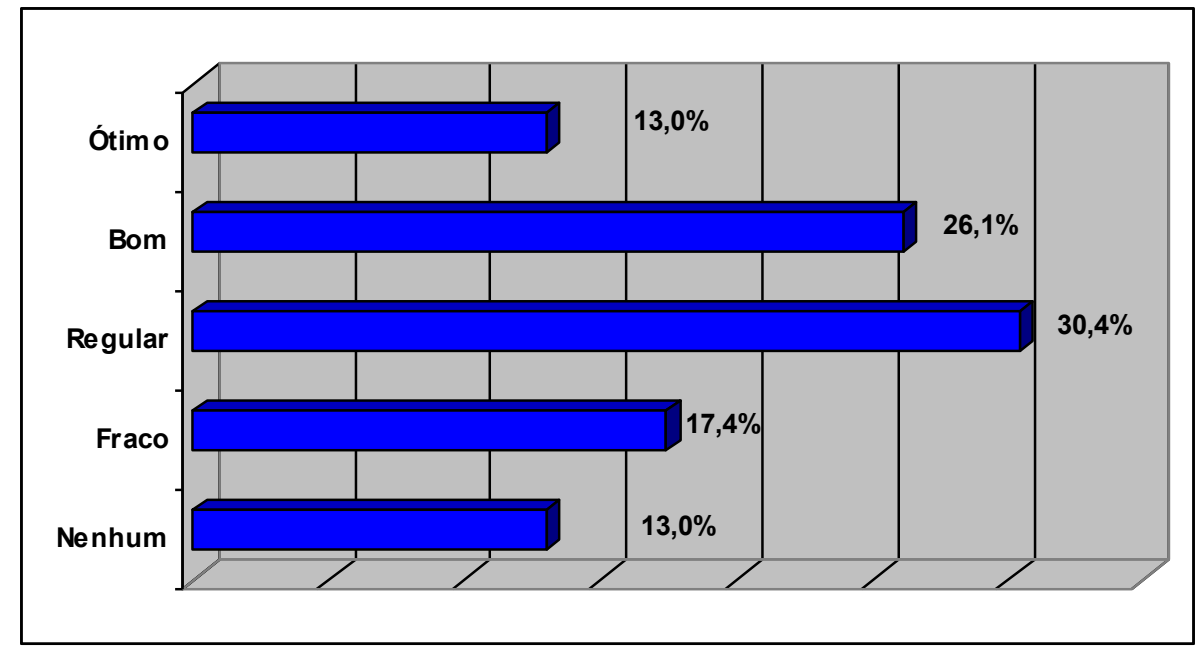


Uma das questões colocadas apenas para a diretoria foi sobre os serviços contratados para implementação de um sistema de gestão ambiental. As respostas foram no sentido da importância da contratação de consultorias, para o planejamento das ações necessárias, incluindo desde o diagnóstico até o treinamento propriamente dito.

Quando questionados sobre a aceitação da implementação de um Sistema de Gestão Ambiental em conformidade com a Norma ISO 14001 dentro da empresa, os entrevistados deram respostas objetivas e ressaltaram a importância de que haja uma continuidade nos treinamentos, e que esse processo não deve nem pode ser interrompido ou suspenso.

$\mathrm{Na}$ apuração dos resultados obtidos nessa questão (Figura 10), as respostas também foram classificadas segundo o grau de aceitação dos funcionários e da alta administração da empresa, conforme a seguinte escala:

- Não sabe dizer, pois não participou da implantação;

- Muito difícil;

- Difícil receptividade;

- Boa receptividade;

- Muito boa.

Importante ressaltar que, para os diretores e para o assessor da Presidência, a pergunta incluiu também a visão deles sobre a opinião dos funcionários. 
Figura 10: Grau de aceitação apontado pelos entrevistados

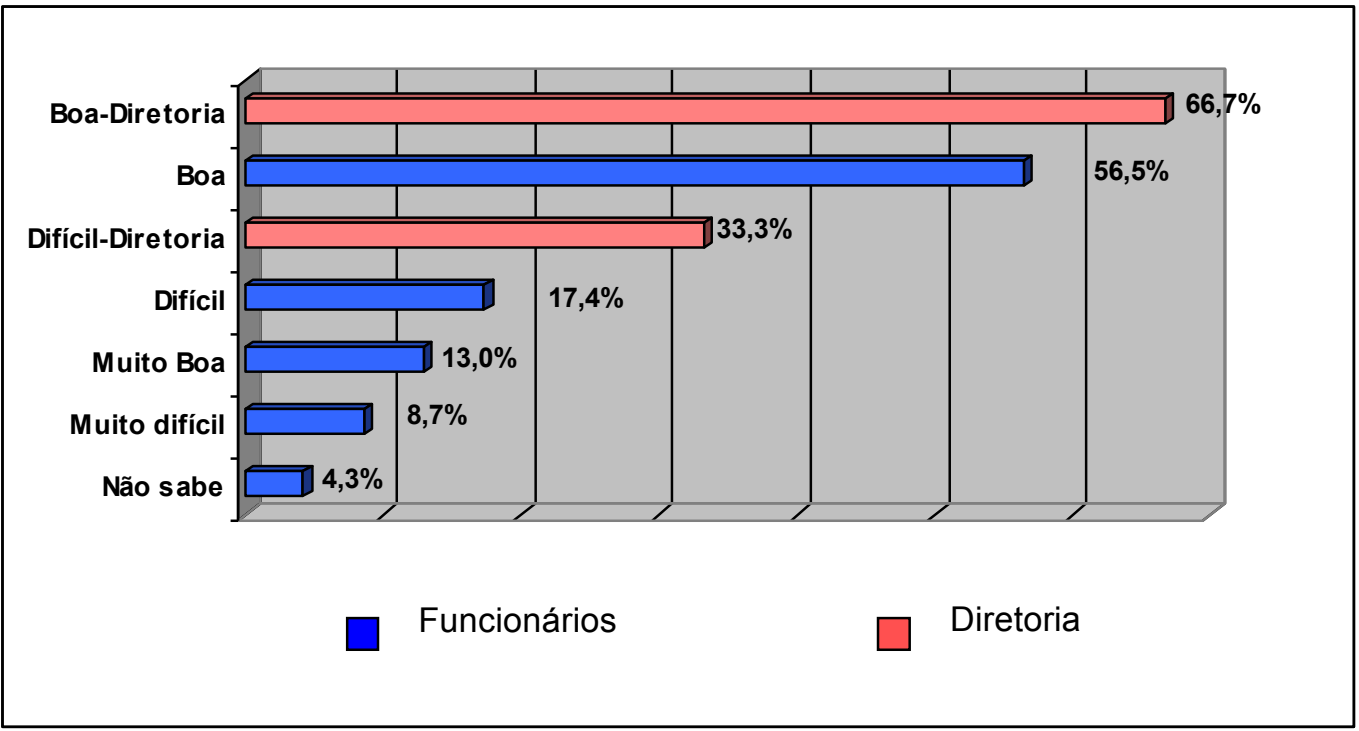

Dentre as respostas da diretoria, 66,7\% alegaram boa receptividade por parte dos funcionários e da alta administração da empresa e 33,3\% dos entrevistados acreditam que houve uma receptividade difícil (Figura 10). Ao analisar os resultados, um dos diretores colocou que:

"No início teve um pouco de resistência. O trabalho de motivação com a diretoria deve ser bem estruturado para demonstrar o compromisso global com o meio ambiente e com o entorno da empresa, assim como com o processo produtivo. E também foi interessante utilizar alguns exemplos de problemas ambientais ocorridos em outras grandes empresas, o que serviu para impulsionar a liberação dos investimentos. Devemos estar cientes de que é uma atividade que exige comprometimento duradouro”.

Entre os entrevistados que acreditaram ter havido uma receptividade muito boa (13,0\%), vale destacar que as respostas foram muito parecidas. Todos alegaram envolvimento geral e compromisso assumido desde a alta administração até o "chão de fábrica". As campanhas, os treinamentos e as palestras de conscientização despertaram em todos eles sentimentos de cidadania, mostrando que, o que se faz na empresa, também pode ser feito em suas residências. 
A maioria dos entrevistados $(56,5 \%)$ acredita ter havido uma boa receptividade. Como exemplo, tem-se:

"Tivemos dois módulos de sensibilização (treinamento realizado pelo SENAI via treinador externo) dentro da área com 98\% de participação. A minha presença foi solicitada nas palestras, pois tinham alguns funcionários que não aceitavam muito bem, por não acreditarem que teria qualquer função prática. Outros tiveram dificuldade de aplicar os conhecimentos obtidos, como, por exemplo, em situações de emergência. Mas a grande maioria (cerca de 90\%) aceitou bem e tinha interesse em aprender".

"Muitos treinamentos e palestras foram dados. As pessoas contribuiram bastante e, uma vez tendo aprendido, elas usam o conhecimento (por exemplo, a coleta seletiva)".

Ao avaliar as respostas dos que consideram a receptividade difícil $(17,4 \%)$, as justificativas são a falta de conhecimento dos colaboradores; a velocidade com que as informações todas deveriam ser absorvidas e incorporadas ao dia-a-dia de todos; resistência da alta administração em se comprometer; altos investimentos (Figura 10). São exemplos as seguintes respostas:

"Houve resistência porque mudança é a principal barreira do ser humano e ainda existe”.

"Deveria ter tido mais tempo. No início teve muita dúvida (dentro e fora da fábrica). Aos poucos, as dúvidas foram sendo esclarecidas e as pessoas passaram a encarar o assunto com mais maturidade e mais cuidado. As pessoas têm interesse e vontade em aceitar e se preocupar com o meio ambiente. Porém, é necessário trabalhar mais a questão, pois na última auditoria verificou-se que houve uma queda no envolvimento dos funcionários".

Entre os $8,7 \%$ dos entrevistados que responderam muito difícil, interessante a resposta apresentada por um deles, dizendo que: "Foi bastante complicado. Como é ação preventiva, não sabíamos quais seriam as conseqüencias e implicâncias do 
processo de gerenciamento (se haveria redução de custos, por exemplo). A demora foi decorrência disso. Nosso trabalho aqui na empresa é muito focado em resultados. Para gastar uma quantia de dinheiro com algo que não estava planejado e que é um sistema muito grande é dificil".

Os 4,3\% que estão classificados como "não sabe" são aqueles que não trabalhavam na empresa na época da implantação e, por essa razão, não poderiam responder essa questão.

Ao perguntar se houve alguma mudança dentro da empresa após a certificação, $82,6 \%$ responderam que $\operatorname{sim}$ e apenas $17,4 \%$ dos entrevistados acreditam que não houve nenhuma mudança, conforme ilustra a Figura 11.

Figura 11: Mudanças ocorridas dentro da empresa após a certificação

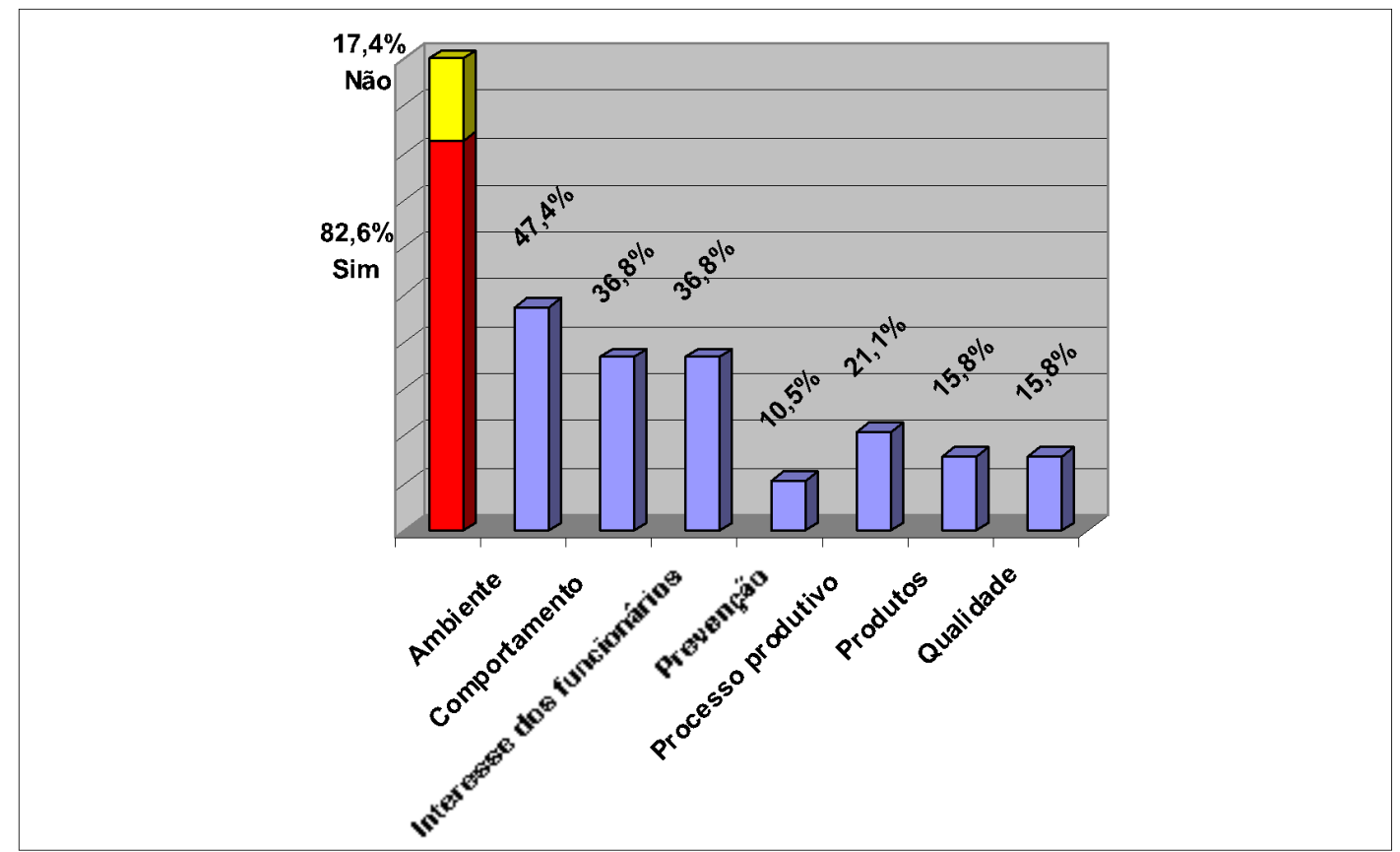

Antes da aplicação da pesquisa, foi preparado um quadro para estimular as respostas caso algum entrevistado não soubesse responder; porém este quadro não precisou ser utilizado, pois todos os entrevistados responderam esta questão. E justamente por todos os entrevistados terem fornecido respostas completas para esta 
questão, apontando mudanças de caráter geral, e, principalmente, mudanças em relação às questões ambientais; é que a pergunta número 6 do questionário não foi necessária. Quando o questionário foi elaborado, fiquei em dúvida se a pergunta número 5 conseguiria obter respostas completas e se as pessoas falariam sobre as mudanças de comportamento ocorridas ao responderem esta questão. Então, para garantir que o tema ambiental seria mencionado, formulei a pergunta número 6 e adicionei um quadro auto-explicativo anexado a ela, conforme segue:

Caso já tenha sido abordado o tema ambiental na $5^{\mathrm{a}}$ questão, pular diretamente para a $7^{\mathrm{a}}$ questão.

"Mudança de comportamento" = percepção, busca de soluções, conscientização, etc.

Isto posto, é importante frisar que as altas porcentagens apresentadas na Figura 11 são decorrentes de respostas múltiplas apresentadas por diversos entrevistados. Como, por exemplo, as mudanças apontadas por um dos diretores, as quais são: modernização da estação de tratamento de efluentes; maior divulgação da responsabilidade ambiental da empresa; criação de procedimentos operacionais padrão para cada atividade que envolva meio ambiente ou resíduo; redução dos custos operacionais; envolvimento dos fornecedores; metas estabelecidas de redução na geração de resíduos.

Para $47,4 \%$ dos entrevistados que responderam que houve mudanças na empresa após a certificação, a maior delas foi o aumento da preocupação e o comprometimento com o meio ambiente (Figura 11). Atualmente, há uma preocupação mais acentuada com a geração e o descarte de resíduos. Além disso, metas ambientais foram incluídas em toda a empresa e começou a existir uma mentalidade voltada para a questão ambiental já no desenvolvimento (projeto) de um novo produto.

Inclusive, foram expostos painéis de orientação contendo conceitos ambientais importantes; curiosidades; figuras ilustrativas; informações referentes aos resultados de sua diretoria, incluindo o desempenho ambiental; e procedimentos operacionais de emergência em cada uma das unidades de trabalho, de maneira que 
todos os colaboradores possam ter acesso a essas questões e, quando necessário, recorram àqueles procedimentos evitando quaisquer danos ambientais (Figura 12).

Figura 12: Foto representativa dos painéis de orientação.

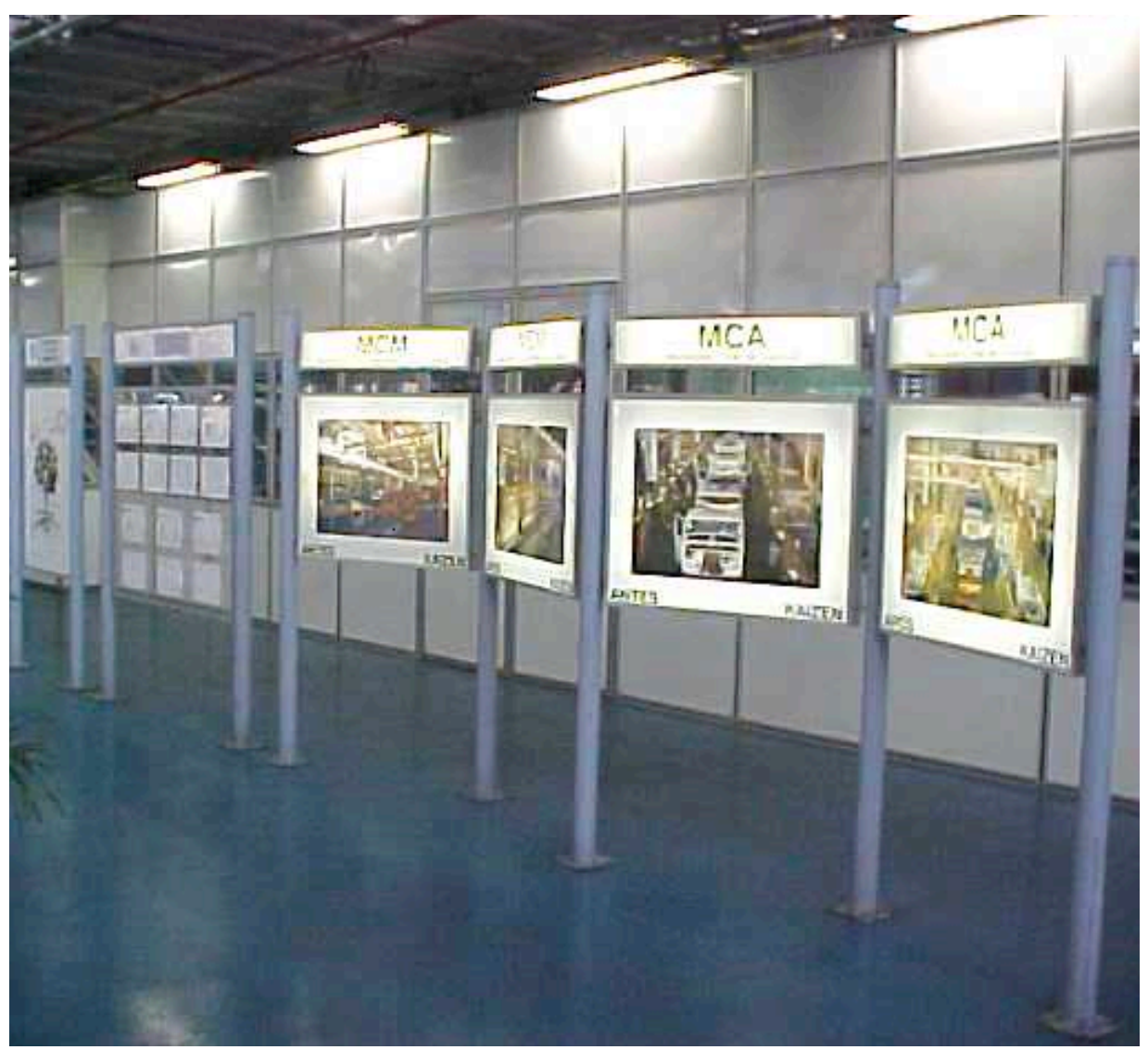

A mudança de comportamento dos colaboradores e o aumento do interesse dos funcionários pelas questões ambientais são as duas mudanças mais significativas ocorridas na empresa após a certificação na opinião de $36,8 \%$ dos entrevistados, cada uma delas (Figura 11). Segundo esses entrevistados, há uma diferença na postura das pessoas que lá trabalham e um maior conhecimento do que pode ou não ser feito, existindo até uma certa cobrança e fiscalização entre os próprios colaboradores. Inclusive, as informações foram levadas para as casas dos funcionários, expandindo para o âmbito familiar e para suas comunidades o interesse pela questão. 
A formação de processos mais enxutos e limpos de produção e demais mudanças dos processos produtivos foi apontada como a principal mudança por $21,1 \%$ dos entrevistados.

Outras duas mudanças importantes apontadas pelos entrevistados foram a melhoria da qualidade do ambiente de trabalho dentro da empresa e o desenvolvimento de produtos "ecologicamente" corretos, com 15,8\% das respostas (Figura 11). Através das entrevistas e das visitas feitas às instalações da empresa, pode-se observar que os locais de trabalho apresentam uma ótima aparência e são extremamente organizados. Um dos entrevistados relatou que há muita diferença de 10 anos pra cá na parte de limpeza e organização no seu ambiente de trabalho, conforme se verifica na figura abaixo (Figuras 13 e 14). E ainda expõe que hoje a preocupação ambiental é mais explícita, o que afeta diretamente os produtos lá desenvolvidos.

Figura 13: Foto da linha de montagem antes do processo de certificação.

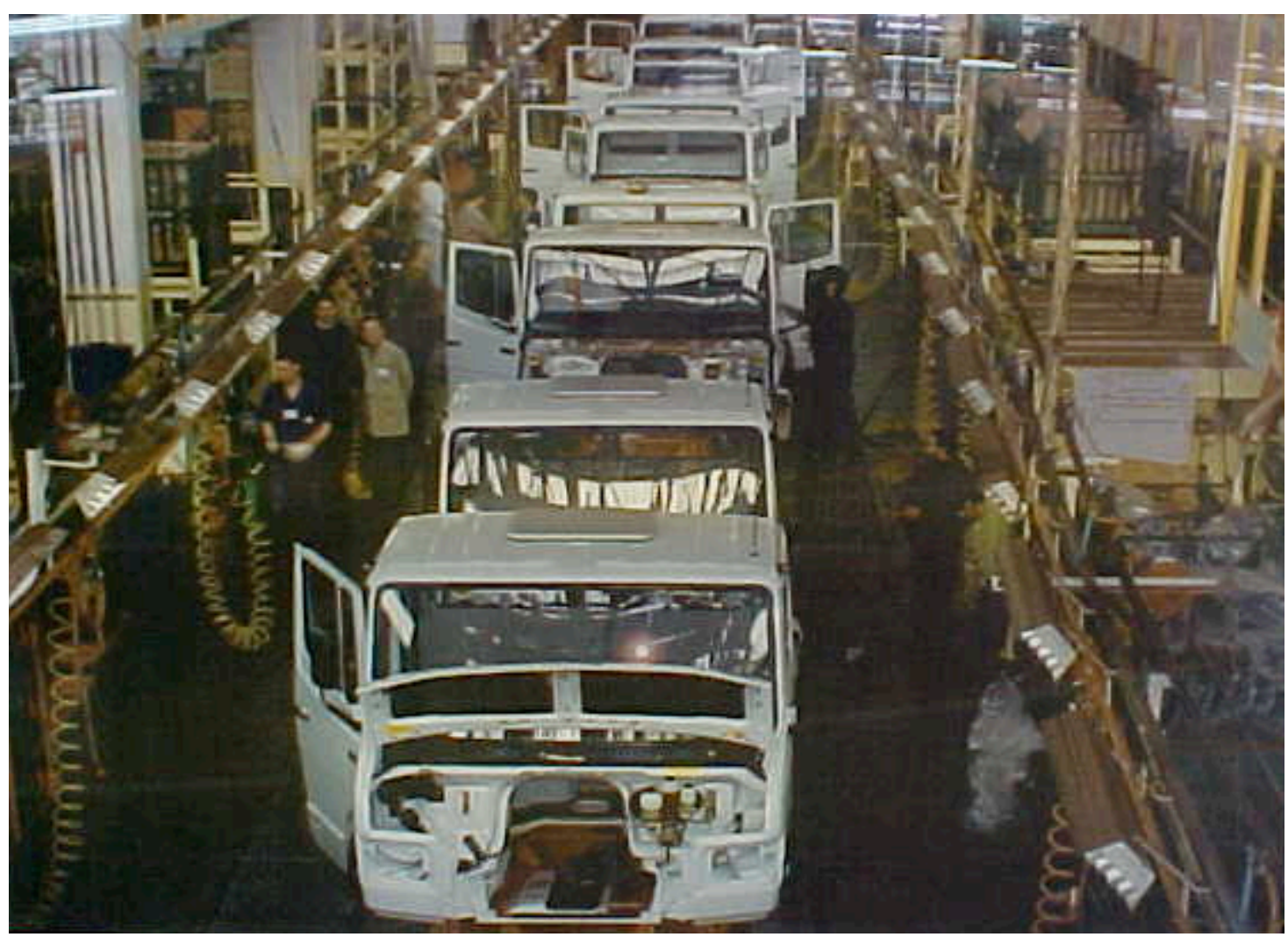


Figura 14: Foto da linha de montagem após o processo de certificação.

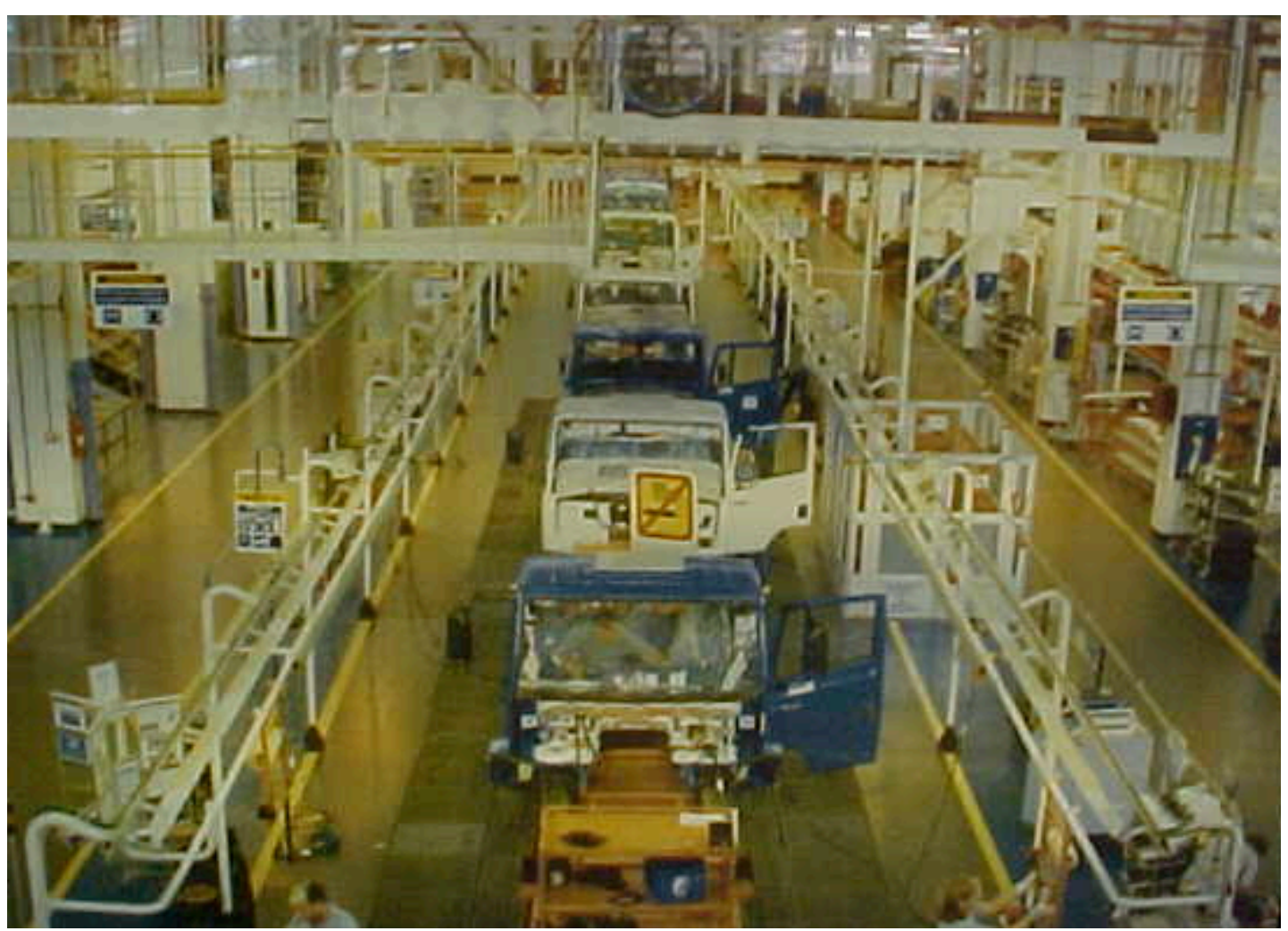

Apenas 10,5\% dos entrevistados apontaram a adoção de ações de caráter preventivo como a mudança mais significativa (Figura 11). Um deles explicou que:

"Os controles existentes hoje são feitos de forma preventiva. Tudo é monitorado e qualquer fato que ocorra, já existe o procedimento adequado para gerenciar aquele risco".

Dentre os $17,4 \%$ que responderam que não houve nenhuma mudança dentro da empresa após a certificação (Figura 11), o argumento utilizado foi de que a certificação não é ponto de referência. Convém destacar duas dessas respostas, para melhor entendimento:

"As mudanças vieram antes da certificação, inclusive a conscientização das pessoas. Já havia coleta seletiva de lixo, já mostrávamos os riscos existentes em cada atividade. De 1994 até 1999, muita coisa mudou. A certificação em si não trouxe mudanças". 
"As mudanças surgiram a partir do momento que se decidiu buscar a implementação de um SGA em conformidade com a Norma ISO 14001 e conseqüente certificação. Durante todo o processo as coisas mudaram, e de forma regular".

E, por fim, um desses entrevistados justificou sua efetiva resposta alegando que ainda existem comportamentos que devem ser trabalhados e, que, uma mudança de cultura demanda mais tempo.

Em um dos primeiros contatos com a diretoria da empresa, foram fornecidos relatórios sociais e ambientais da empresa e outros materiais elucidativos. Um desses materiais era uma apresentação elaborada pela própria empresa para treinar os colaboradores que seriam os integrantes do Grupo Multifuncional (que têm como função disseminar a questão ambiental dentro de cada área da empresa). Esta apresentação foi o principal material utilizado no Curso de Integração de Colaboradores em Gerenciamento Ambiental, contendo dados conceituais; explicando o que é SGA e quais seus objetivos; indicando o responsável de meio ambiente em cada área; apontando o que a Norma ISO 14001 requer; e, por fim, os resultados esperados com a implementação de um SGA em conformidade com a Norma ISO 14001.

Utilizando esses resultados listados como sendo aqueles esperados pela direção da empresa ao obter a certificação, e incluindo outros fundamentais, foi elaborada a pergunta número 7 do questionário, almejando conhecer quais desses resultados já foram alcançados pela empresa. E se, por acaso, ainda não tenham sido atingidos, por qual razão.

É importante avaliar, dentre os objetivos estipulados por uma empresa ao implementar um SGA em conformidade com a Norma ISO 14001, quais deles puderam ser atingidos após dezenove meses da certificação. E, caso ainda não tenham sido, o que falta para conseguir? Dessa maneira, os que se interessarem pelo assunto e se determinarem a seguir o mesmo caminho em suas próprias organizações, poderão se organizar; elaborar um cronograma de implantação; destinar um bom 
tempo à realização de um diagnóstico o mais próximo possível da realidade, para evitar surpresas com altos investimentos; investir em treinamento e conscientização de todos os níveis da organização; e, assim, alcançar todos os seus objetivos, sempre se adequando a novos processos, equipamentos, a fim de buscar continuamente maior eficiência na proteção ambiental, visando o desenvolvimento sustentável.

Os resultados foram separados em itens e para cada um deles, o entrevistado deveria dizer se, na opinião dele, aquele resultado havia sido alcançado ou não, e, se tivesse algum comentário a fazer ou justificativa a apresentar, poderia fazê-lo.

O primeiro item representa os resultados esperados no aspecto econômicofinanceiro, os quais são: agregar valor ao negócio da empresa; redução de custos; economia de recursos financeiros.

Com relação a questão sobre se a certificação ISO 14001 agregou valor ao negócio da empresa, $82,6 \%$ dos entrevistados alegaram que sim, como explica um deles:

"Estão trabalhando para agregar valor, com menor emissão de poluentes, com motores mais modernos. Só que produzir motores mais modernos sai mais caro, então não há economia de recursos".

Quanto à redução dos custos, 56,5\% acreditam que esta meta está sendo alcançada por meio de campanhas para evitar desperdícios, com o melhor aproveitamento dos recursos e com a preocupação com a destinação final dos resíduos. Um dos diretores colocou que:

"Com a coleta seletiva, há uma redução na geração de resíduos. Menor volume de resíduos perigosos e, conseqüentemente, menor risco de contaminação. Não utilizamos aterros para resíduos de classe 1. Os resíduos de classe 1 são coprocessados ou incinerados. Menor custo no processamento de resíduos. Meta empresarial de redução no consumo de água e energia elétrica”. 
Entre os 21,7\% dos entrevistados que disseram que este resultado ainda não foi alcançado, a justificativa apresentada foi de que esta redução de custos somente será percebida com o tempo. Convém destacar as seguintes respostas:

"Hoje meio ambiente ainda é visto como gasto (compra de material, conscientização, etc.). A proteção do meio ambiente demanda custos com as modificações dos processos de produção. Se houver redução de custos, será percebido só com o tempo (4 ou 5 anos)".

"Não houve redução de custos, não nos primeiros dois anos, mas agora começou a ser percebido. Mas sem dar lucros. Questões ambientais não dão lucro mas reduzem custos por exemplo com redução de resíduos".

Outros entrevistados disseram não ter conhecimento sobre os resultados financeiros $(21,7 \%)$, pois trabalham nos setores mecânicos e técnicos. Com relação à economia de recursos financeiros, $60,9 \%$ dos entrevistados dizem que as campanhas de racionalização de água e energia elétrica têm proporcionado bons resultados nesse sentido. Tem-se como exemplo a resposta abaixo referida:

"Trabalhamos com mais economia, reduzimos a utilização de materiais portanto há economia de recursos financeiros".

Os 30,4\% de entrevistados que responderam que não foi possível detectar economia de recursos financeiros destacam que esse resultado será atingido daqui a alguns anos,e, aí sim, poderão fazer um balanço.

O segundo item da pergunta 07 questiona se foram eliminados os riscos de novas e futuras vulnerabilidades legais. A grande maioria dos entrevistados acredita que sim, representando $95,7 \%$ das respostas. Dentre as explicações e justificativas apresentadas, destaca-se a conscientização e responsabilidade ambiental; a preocupação com a legislação ambiental e a adoção de ações de caráter preventivo. Convém destacar algumas delas: 
"Com os processos sistematizados, os riscos de ocorrência de um acidente ambiental diminuem, bem como as possibilidades do não-atendimento a algum requisito legal”.

"Os dirigentes e a alta administração vêem essa questão com muita seriedade por causa da lei de crimes ambientais de 1998”.

"Licenças ambientais que foram buscadas por causa da certificação. Maior importância à correta destinação de resíduos e tratamento de efluentes".

"Por exemplo, havia um tanque de refrigeração que tinha risco de transbordar e ocorria transbordo. Na implantação tivemos que solucionar esse aspecto e armamos um sistema de sensores para evitar o transbordo. Não tivemos mais problemas desde então. Diversos casos em que havia situações de risco e acabaram sendo evitadas ou controladas (atuação preventiva)”.

"Ocorre com freqüência abertura de relatórios para emergências ambientais e todo o procedimento previsto para gerenciar e resolver essa emergência, de modo que não se repita”.

"Há um risco constante. Esse item foi implantado, mas só funciona com fiscalização. Não está $100 \%$ garantido pois minha visão é a de que um sistema só funciona perfeitamente se as pessoas não precisam mais ser fiscalizadas".

O gerenciamento com maior eficácia das questões ambientais e a melhora na qualidade de vida são os resultados apresentados no terceiro item da pergunta 07 . Quando questionados se o gerenciamento mais eficaz das questões ambientais já havia sido obtido, todos os entrevistados responderam que sim, ou seja, 100\%. E as razões apresentadas para esta mudança foram a conscientização e a responsabilidade ambiental, como pode-se observar com estas respostas: 
"Gerenciamento efetivo, com possibilidade de mensuração dos aspectos gerados (residuos, por exemplo); controle operacional dos aspectos ambientais significativos".

"O sistema foi pulverizado. Há o gerenciamento das tarefas com mais qualidade, melhor produtividade, com conhecimento de como elas impactam o meio ambiente e como controlar o comportamento para não causar problemas".

"Houve grande envolvimento das pessoas que participaram do processo de implantação do SGA. Todos falávamos a mesma linguagem. Depois da certificação, essa questão perdeu um pouco a importância. Com o SGI voltou à tona. O gerenciamento ambiental tem mais eficácia quando estamos próximos de avaliações, mas isso não quer dizer que o resto do tempo ninguém faça nada. Só acho que deveria ter sempre a mesma importância”.

No momento em que os entrevistados foram questionados sobre a melhora na qualidade de vida, $87,0 \%$ acreditam que houve uma melhora significativa e as razões apresentadas foram variadas. Ao analisar essas respostas, percebe-se que a mais citada foi a criação e implantação de trabalhos com a comunidade local. As demais razões relatadas foram a mudança de comportamento dos funcionários; o aumento do interesse destes pelas questões ambientais e alterações no ambiente de trabalho. São exemplos algumas respostas:

"A melhora na qualidade de vida é notada desde a implantação da coleta seletiva até o interesse das pessoas pela questão ambiental. Manutenção da limpeza no local de trabalho".

"Houve melhora na qualidade de vida porque foi criado um programa de qualidade de vida. Hoje existe um grupo que cuida dessas questões: com ações localizadas, como por exemplo o Projeto Pessoa, Campanhas de Saúde, etc.”.

"Fábrica mais limpa e segura para os funcionários". 
"A melhora na qualidade de vida engloba não só o ambiente da empresa, como também o entorno, como por exemplo: eliminação de produtos tóxicos, menor exposição dos funcionários a riscos, redução da geração de resíduos (tanto na produção como na manutenção - exemplo: troca de óleo no motor), reutilização dos resíduos (reciclagem do óleo lubrificante, por exemplo). A sociedade sente esses reflexos".

Os entrevistados que alegaram não ter percebido qualquer mudança em relação à melhora na qualidade de vida, justificaram sua resposta dizendo que já tinham uma boa qualidade de vida e, com a certificação, continuaram tendo.

$\mathrm{O}$ quarto item da pergunta 07 apresentou outros dois resultados que eram esperados pela empresa com a obtenção da certificação: obtenção de maior vantagem competitiva sustentável e oportunidades de participação em futuros negócios. Os entrevistados $(82,6 \%)$ acreditam que houve um aumento considerável da vantagem competitiva sustentável, que é uma meta empresarial. Eles alegam que a empresa está preparada para atender mercados cada vez mais exigentes e que a diversificação de produtos e processos ambientalmente responsáveis aumenta bastante a competitividade da empresa. Um dos diretores explicou como atingir esse resultado: "Maior enfoque na avaliação do impacto ambiental. Integração da variável ambiental no planejamento estratégico da empresa. Acompanhamento de ameaças e riscos. Vantagem competitiva. Objetivo é diminuir a degradação ambiental e, em alguns casos, reverter a situação. Exemplo: A política nacional de resíduos sólidos está para ser aprovada. Há um artigo que é sobre reciclagem de veículos. Se amanhã sair, tenho que estar preparado para isso".

Muito interessante a resposta apresentada por um dos assessores da presidência, que colocou:

"Esta é uma discussão muito presente na empresa. Quantos caminhões a mais foram vendidos pelo fato de termos ISO 14001? Não vende mais por causa da ISO, mas evita deixar de vender. Se eu não tiver, corro um risco ambiental tão grande de, por exemplo, ter minha fábrica interditada. Para concorrências internacionais é 
importante ter um sistema implantado e os certificados ISO. Diferencial importante".

Como resultado de uma maior vantagem competitiva, aumentaram as oportunidades de participação em futuros negócios, na opinião de 91,3\% dos entrevistados. Estes consideram importante para as concorrências internacionais ter um sistema de gestão implantado e os certificados ISO. Acreditam ser um diferencial competitivo, como se pode observar em algumas respostas:

"A certificação é necessária para o fechamento de vários negócios. Se eu não tiver o certificado, futuramente posso deixar de vender para esses mercados".

"Muitos clientes têm solicitado além da ISO 9001, também o certificado ISO $14001 "$.

“Há uma preocupação, por parte das empresas, em relação ao tema ambiental para se manter no mercado".

Somente $4,3 \%$ não acreditam ter havido uma mudança significativa neste aspecto, justificando esta opinião conforme segue:

"Abre-se, mas ainda não é fator determinante".

A melhoria da imagem da empresa é um tema que despertou o interesse dos entrevistados $(95,7 \%)$, propiciando um debate intenso sobre o assunto. Exigiu até um desdobramento da pergunta, incluindo um sub-item para que eles pudessem dizer para quem houve essa melhoria de imagem da empresa (Figura 15). Quando questionados sobre para quem eles acreditam ter havido essa melhora, as respostas estão apresentadas na figura abaixo: 
Figura 15: Mudança de imagem da empresa após a certificação.

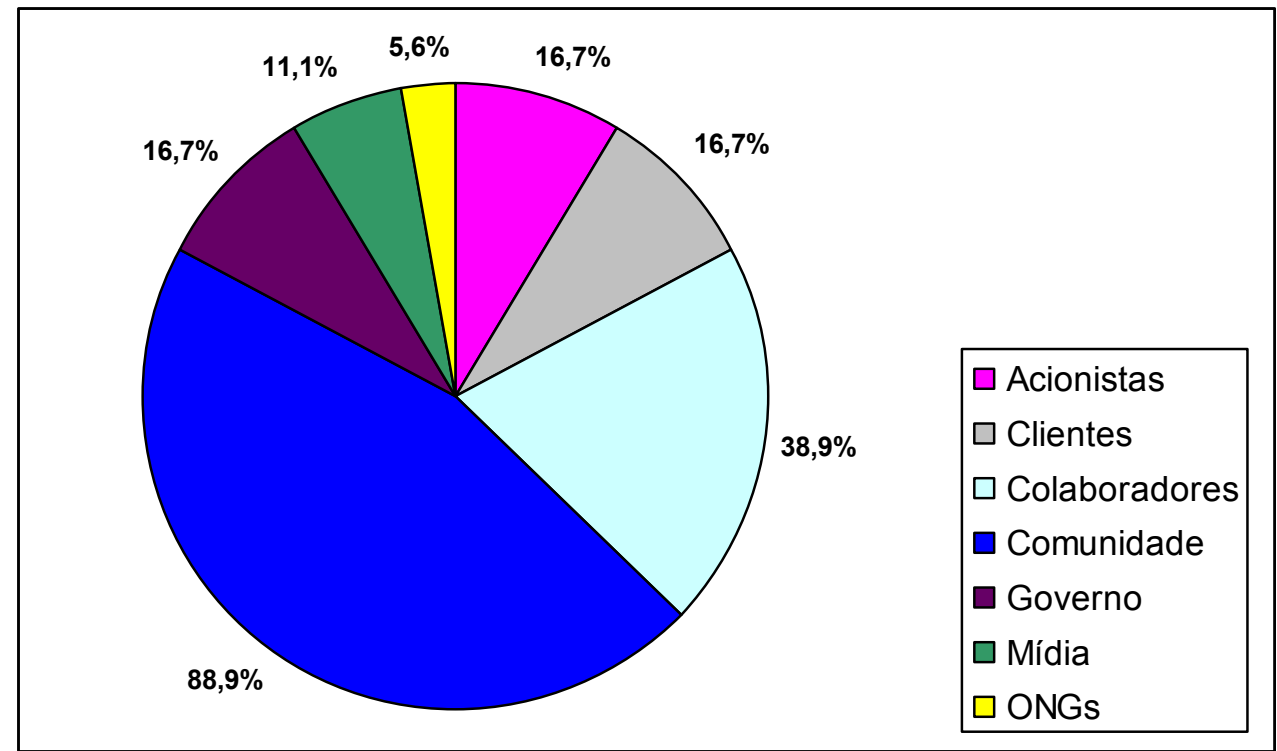

Convém destacar algumas das respostas apresentadas para justificar a opinião dos entrevistados que acreditam ter havido melhora na imagem da empresa, devido ao surpreendente interesse pela questão e à riqueza das respostas. E também porque vários entrevistados sentiram as diferenças eles mesmos e sentiram os reflexos na comunidade local. São exemplos:

"Faz parte da norma o procedimento de comunicar os procedimentos ambientais. $O$ aspecto ambiental interfere na qualidade de vida. Criamos um canal de comunicação com a comunidade. As pessoas vêem que a empresa faz algo a mais".

“As melhorias são divulgadas e qualquer reclamação da comunidade vizinha é encaminhada imediatamente para a área responsável, que busca a solução mais adequada”.

"Por exemplo, a comunidade sofria com a poluição sonora causada pelos altofalantes dos caminhões dos fornecedores. Hoje essa comunicação é feita através de bips eliminando qualquer incômodo para a vizinhança”.

"Público interno e externo. Divulgação de 'releases' para a imprensa. Contato com a comunidade em relação a problemas ocorridos. As telefonistas foram treinadas 
para atender as reclamações da comunidade. Decisão de que todas as demandas por informações relacionadas ao meio ambiente serão encaminhadas para a área de comunicação".

"Comunidade interna e para o entorno da empresa. Trabalhos comunitários (Vila Paulicéia) de reciclagem. Incentivo ao pessoal para criar uma filosofia ISO 14001 em suas próprias casas”.

"Junto à sociedade, para que se tenha uma boa imagem de seu produto também. A sociedade está muito mais atenta e podemos perceber isso com o destaque que se dá na mídia para essas questões”.

"Visão da comunidade de uma empresa comprometida com o meio ambiente".

"A implementação concreta melhora a imagem geral da empresa. É um diferencial competitivo e hoje somos uma empresa que não tem só o certificado e sim um SGA implementado, os riscos gerenciais já estão listados e gerenciados”.

O único entrevistado que respondeu negativamente a esta questão justificou sua opinião no fato de que a empresa já tinha uma boa imagem relativa à preocupação ambiental antes da certificação.

O último item trouxe à discussão o principal ponto da Norma ISO 14001: o envolvimento de todos os colaboradores da empresa com o processo de implementação do SGA e conseqüente certificação. A maioria $(95,7 \%)$ alega que há uma maior conscientização e percepção de todos os colaboradores em relação à questão ambiental após a obtenção do certificado. Os colaboradores tornaram-se mais conscientes de que, ao realizarem suas atividades levando em consideração a preocupação com a questão ambiental, estariam realizando um bem à empresa, à sua qualidade de vida e de seus familiares. Porém, um deles expôs o seguinte:

"Mas o processo é lento e o aprendizado deve ser reiterado sistematicamente. Temos na empresa o treinamento chamado 'Diálogos de 5 minutos', com temas sobre meio 
ambiente e segurança, realizados toda semana, que têm conseguido bons resultados para mudança de cultura das pessoas”.

Os 4,3\% restantes não acreditam ter havido mudanças significativas nesse sentido, como se observa nessa resposta:

"Nunca vai atingir a plenitude. O processo evolui sempre. Apesar dos funcionários acompanharem as mudanças, não é na mesma velocidade com que estas ocorrem. Apenas nas áreas específicas em que os funcionários estão diretamente envolvidos será possível acompanhar as mudanças, mas não de uma forma geral”.

Um dos aspectos importantes para a certificação é a possibilidade de abrir ou ampliar mercado para exportação. Quando questionados se acreditam que a certificação trouxe alguma modificação nesse sentido, $34,8 \%$ dos entrevistados disseram que sim. Têm-se como exemplos:

"Sim. A empresa já tinha um grande mercado de exportação sendo explorado, mas alguns de nossos clientes novos têm solicitado cópia de nosso certificado para fecharmos o negócio”.

"A certificação proporciona novas exportações de motores menos poluentes para países de primeiro mundo. Somos o único país do mundo a exportar para os Estados Unidos: 40.000 motores vendidos porque o motor da empresa atende à exigência feita por eles de controle de emissão de particulados".

"Não é determinante mas faz diferença sim. A partir do momento que você tem um sistema e funciona, você consegue explorar isso comercialmente. Mas não pode ser puro marketing. Deve ser concretizado para surtir efeito. A iniciativa de utilizar fontes renováveis nos produtos foi da empresa. Demos a partida e agora os concorrentes se adequaram. No setor automobilístico temos muitos segredos industriais e tecnologias por trás disso e o que vai fazer diferença é a qualidade deles. Nossa imagem é muito forte em inovações". 
Outros 34,8\% dos entrevistados disseram não ter havido mudanças nem ampliação de mercado para exportação porque a empresa encontrava-se preparada para as exigências de programas de exportação. Ao analisar as justificativas dadas, um dos entrevistados colocou que:

"O produto da empresa atende à legislação de diversos países. Aliás, já atendia. Então o mercado está aberto para nossa empresa”.

E outro entrevistado apresentou um ponto de vista diferente dos demais, que acredito ser interessante destacar:

"Não. Houve um maior ganho de mercado externo motivado pela qualidade do nosso processo produtivo, e não pela certificação ambiental. Um exemplo de empresa que precisa disso para se diferenciar e ser aceita pelo mercado externo é a indústria de papel e celulose. Para as montadoras não faz diferença”.

Os 30,4\% restantes alegaram não ter conhecimento suficiente sobre o assunto para poder opinar. Inclusive, um dos diretores disse que ainda não acredita ser possível ter uma posição concreta sobre esse assunto, como se pode observar:

“Com a ISO 9001 houve mudanças significativas, mas com a ISO 14001 não sei informar. Mas existe a possibilidade que ocorra alguma mudança, em breve, caso o mercado externo exija 'selos ambientais',".

Ao se perguntar aos entrevistados quais foram as principais dificuldades e conflitos encontrados no processo de certificação, 52,2\% responderam que era a conscientização em todos os níveis (Figura 16). Seguem algumas colocações:

“Colocar, para todos os níveis (desde a diretoria até o chão de fábrica), a cultura de que nós devemos cuidar do meio ambiente; e de que é necessário investir para atingir esse objetivo. Maior dificuldade é a conscientização em todos os níveis”.

"A mudança deve ser feita com base em atitudes e comportamento das pessoas, o que é difícil por si. A conscientização e a incorporação da cultura é a parte mais difícil. O aspecto técnico é fácil". 
Figura 16: Maiores dificuldades encontradas durante a certificação

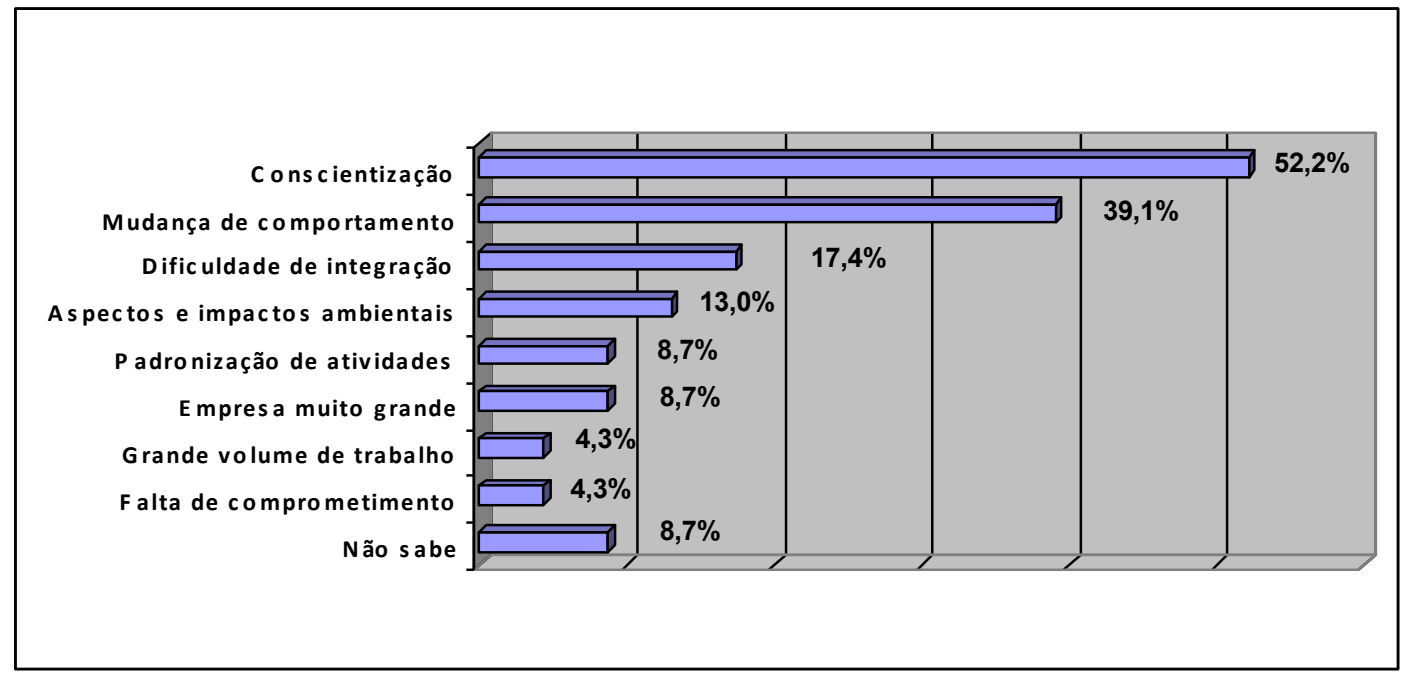

A principal dificuldade encontrada para $39,1 \%$ foi a mudança de comportamento, como os exemplos abaixo citados:

"A maior dificuldade foi a mudança de cultura, que esbarrou na resistência das pessoas em mudar comportamento (atitudes)".

"Dificuldade das pessoas entenderem o porquê das mudanças naquele momento. Temos que explicar que o mundo está mudando e que certas atitudes que tomávamos no passado hoje são erradas. Fazíamos porque não sabíamos que era errado e agora temos que mudar".

Outro conflito encontrado no processo de certificação, de acordo com a opinião de 17,4\% dos entrevistados, foi a dificuldade de integração entre os colaboradores e a alta administração (decorrente de dificuldades de relacionamentos interáreas e interpessoal). Um exemplo poderia ser a resposta de um deles, conforme segue:

"Em algumas áreas houve dificuldade de integrar a alta administração ao processo de implantação”. 
O levantamento de aspectos e impactos ambientais foi lembrado por $13,0 \%$ dos entrevistados como uma grande dificuldade (Figura 16), como explica este entrevistado:

"Levantamento dos aspectos e impactos ambientais (que é a base do sistema: analisar todas as atividades e dizer o que era impactante e o que não era)".

A padronização de atividades e o tamanho da empresa foram as maiores dificuldades encontradas durante a implementação do SGA e conseqüente certificação em conformidade com a Norma ISO 14001 na opinião de 8,7\% dos entrevistados (Figura 16).

Tem-se como exemplo a opinião de um dos colaboradores da empresa: "Houve dificuldades no processo de implantação por ser uma empresa muito grande. Especialmente na fase de levantamento de aspectos e impactos ambientais, que são muito diversificados, e por esta razão levou muito tempo".

Outras duas dificuldades referidas pelos entrevistados $(4,3 \%)$ durante o processo de certificação foram: a falta de comprometimento, tanto da alta administração como dos funcionários; e o grande volume de trabalho (Figura 16).

Os $8,7 \%$ que estão classificados como "não sabe" são aqueles que não trabalhavam na empresa na época da implantação e, por essa razão, não poderiam responder essa questão.

Alguns entrevistados apresentaram respostas múltiplas para esta questão (Figura 16), apontando mais de um motivo, como, por exemplo, um dos diretores: "Mudança de comportamento. Modificação na infra-estrutura: implantação da parte de reciclagem interna (venda de sucata não é reciclagem) com construção de prédios para separação de resíduos. Trabalho difícil com a conscientização dos fornecedores para fornecer produtos e embalagens recicláveis. Novos contratos de destinação final de resíduos. Abrangência muito grande. Não é implantada só na fábrica, tem que varrer a cadeia desde o fornecedor da peça do caminhão, passando 
pelo prestador de serviços e pelo processo produtivo, até a concessionária que vai distribuir o produto".

Com relação aos resultados obtidos nas questões referentes à legislação ambiental brasileira, os entrevistados aproveitaram para emitir opiniões pessoais sobre a elaboração e cumprimento dessas leis e, também, apontar falhas. Duas questões foram elaboradas a respeito da atual legislação brasileira, de modo a avaliar o conhecimento dos entrevistados sobre o assunto. Lógico que não era esperado um conhecimento detalhado sobre leis, considerando os cursos universitários e as funções de cada um. Porém, as críticas apontadas e as opiniões sobre a dificuldade de cumprimento das leis no nosso país foram interessantes.

A primeira delas expõe a recente mudança ocorrida no processo de licenciamento ambiental no estado de São Paulo, exigindo-se a renovação periódica das licenças, conforme disposto no Decreto Estadual no 47.397/02. O questionamento é se a existência de um SGA implementado e a certificação ambiental pode trazer facilidades para a empresa nesse processo renovatório, sendo que 56,5\% dos entrevistados acreditam que sim (Figura 17).

Figura 17: Facilidades obtidas com a ISO 14001 referidas pelos entrevistados.

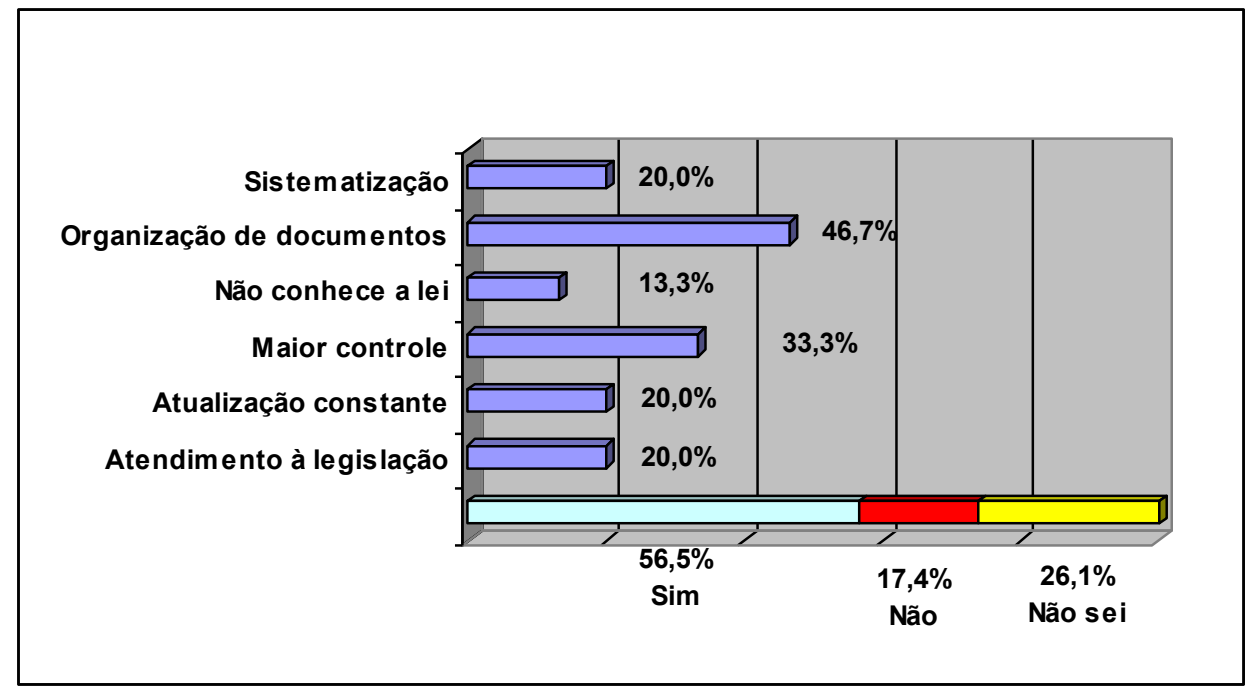


Dentre essas respostas, a justificativa apresentada por $46,7 \%$ dos entrevistados é a de que a ISO traz a organização da documentação do sistema, o que facilita o cumprimento das exigências da legislação. Foi criada uma área que só cuida dessa parte de licenciamento e atualização da legislação.

A ISO 14001 exige que certos procedimentos operacionais sejam padronizados e estabelece um sistema ordenado e metódico, o que facilitará a renovação das licenças ambientais, na opinião de 33,3\% dos entrevistados (Figura 17). Um deles explicou o seguinte:

“A certificação é um subproduto, o importante é o sistema de gestão implantado e esse sim pode ajudar a renovar. O sistema foi implantado para seguir as conformidades legais, o que antes não se sabia. Quem vai cuidar do quê e como fazer. O risco de ser surpreendido na renovação de uma licença é mínimo”.

Os fatores que facilitarão a renovação periódica do licenciamento ambiental são variados, de acordo com as respostas obtidas, como se pode observar: $20,0 \%$ dos entrevistados acreditam que a certificação facilitará pois ela resulta em uma atualização constante das leis; outros $20,0 \%$ alegam que as facilidades advêm da sistematização resultante de um processo de certificação; e mais 20,0\% dizem que a ISO proporciona o atendimento irrestrito às leis. Para melhor entendimento, convém destacar uma resposta de cada uma dessas vertentes, conforme segue:

"Temos uma sistemática que exige que tenhamos um processo definido. Dentro de um SGA, fica claro de quem são as responsabilidades e como deve ser feito. Então facilita a atualização constante do processo e garantir que ele esteja sendo cumprido".

"Sim, já trouxe. A sistematização em si já facilita o processo. O diagnóstico inicial criou muitas vulnerabilidades e por isso fizemos uma revisão de todas as licenças. Organizamos toda a parte documental e hoje só atualizamos".

“Sim. Atender a legislação é o primordial, que devia ser feito de qualquer jeito". 
O não-conhecimento da lei foi a justificativa apresentada por $13,3 \%$ dos entrevistados, como este colaborador argumentou:

"Acompanho o levantamento da legislação, mas ainda não conheço a lei. Acho bom ter que renovar e a CETESB verificar se o que ela colocou na licença está sendo cumprido. Não sabe se será possível cumprir, mas é uma idéia positiva. Será que a CETESB vai ter um quadro de funcionários que possibilite aplicar essa lei na prática (dispor de funcionários para fazer as renovações das licenças)?"

Dos $17,4 \%$ que disseram não acreditar que haverá mudanças no processo de licenciamento (Figura 17), interessante destacar a resposta deste entrevistado:

"Não necessariamente a certificação ISO 14001, mas o processo interno de licenciamento ter um 'procedimento sistematizado', onde temos um maior conhecimento do que existe hoje na fábrica. Isto é, realizado todo o levantamento minucioso dos processos, equipamentos, máquinas, áreas da empresa, etc., fica mais fácil um processo para renovação”.

Os $26,1 \%$ que responderam "não sei" são aqueles que não se consideram aptos para falar do assunto e esclareceram que existe um setor dentro da empresa que cuida especificamente disso.

$\mathrm{Na}$ segunda questão sobre legislação, os entrevistados emitiram opinião pessoal sobre a relação entre a atual legislação ambiental brasileira e os interesses da empresa. Na realidade, o objetivo é avaliar o conhecimento dos colaboradores sobre as leis ambientais. Com 39,1\% das respostas, ficaram os entrevistados que, além de ter conhecimento sobre leis, ainda apontaram algumas falhas da nossa legislação. $30,4 \%$ dos entrevistados emitiram opiniões contrárias à legislação atual. Os outros $30,4 \%$ preferiram não responder a esta questão, por ter pouco conhecimento sobre o assunto (Figura 18). 
Figura 18: Opiniões dos entrevistados sobre a legislação ambiental atual.

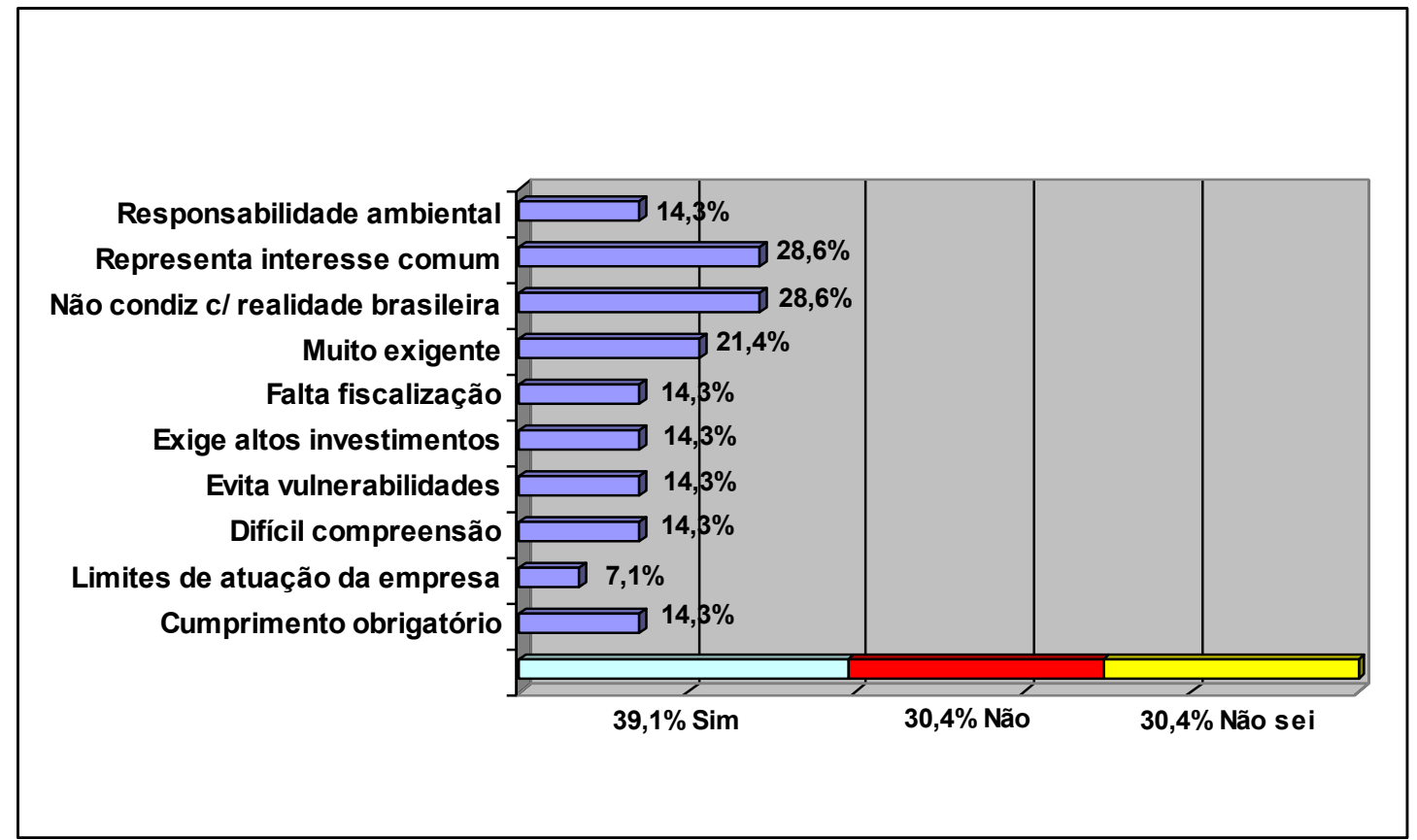

As razões apresentadas por aqueles que não acreditam que a legislação atual atenda aos interesses da empresa são as seguintes: 28,6\% alegam que a legislação não condiz com a realidade brasileira; $21,4 \%$ acham que as leis são muito exigentes; $14,3 \%$ consideram as leis difíceis de entender; $14,3 \%$ apontam que o problema é a falta de fiscalização; $14,3 \%$ atestam que a legislação tem que ser feita para atender aos interesses da sociedade e não para beneficiar a empresa; $14,3 \%$ reclamam que a legislação exige investimentos muito altos; e, por fim, 14,3\% defendem que as leis têm que ser atendidas de qualquer jeito.

Ao analisar as sete justificativas apresentadas por aqueles que acreditam que a legislação atende aos interesses da empresa, importante destacar algumas delas:

“A política interna é meramente corporativa. Faz parte do nosso negócio. Há trocas de informação com as outras unidades (internacionais). Isso evita algumas vulnerabilidades".

"Existe uma lei para cada ponto específico do meio ambiente, que determina os limites de atuação da empresa. Como as leis nacionais são mais brandas e a 
empresa segue uma legislação até mais restrita devido aos padrões exigidos pela matriz, nosso sistema está além das expectativas".

"Salvo alguns poucos instrumentos legais que dificultam o processo (por serem, digamos, extremamente dificeis de interpretar e atender), acho que a legislação ambiental é bastante complexa e bem elaborada. No entanto, acho que para uma empresa comprometida com a preservação ambiental, o cumprimento da legislação é uma conseqüência inevitável e não uma exigência. Tem que haver responsabilidade ambiental".

Vários entrevistados também apresentaram respostas múltiplas para esta questão (Figura 18), apontando mais de um motivo, como, por exemplo:

"Muito exigente. Falta fiscalização. Muitos detalhes. Ter que acompanhar toda a legislação e garantir que toda ela esteja sendo cumprida é muito difícil. Acredito que deveria ser mais voltada para a realidade brasileira. Nossa legislação ainda é muito copiada, principalmente a parte técnica. Muitas vezes surgem leis por interesse exclusivamente politico, o que prejudica tanto o setor industrial como a sociedade”.

"A legislação existe para atender os interesses da sociedade. Toda e qualquer lei existe para que a sociedade possa viver em harmonia. São as regras do jogo. $O$ problema é importar as leis de outros lugares, que já aplicam a vinte anos, e querer que funcione aqui em um curto prazo (de 2 a 3 anos). Temos que nos encaixar nas 'regras do jogo'. A legislação gera trabalho e um custo adicional para a empresa, mas tem que ser cumprida".

"A minha resposta para esta pergunta é sim e não. Vou explicar.

Falando como empresa que busca resultado econômico, não. Muito exigente para a realidade brasileira. Estamos agregando custos no nosso processo que não beneficiam a economia brasileira. Quando o processo fica muito restrito por exigência da lei, encarece e impossibilita o retorno total. Resulta em um produto mais caro. 
Porém, quando a lei restringe mais tenho uma qualidade de vida melhor. $O$ colaborador fica mais satisfeito pela vida dele lá fora e pela vida dele dentro da empresa. Um colaborador mais satisfeito, produz melhor e com mais eficácia.

Como brasileiro, acho que a legislação tem que restringir bastante. É necessário capacitar melhor os órgãos de fiscalização para que haja um monitoramento mais adequado de como estão sendo implantados os processos produtivos. O órgão ambiental não consegue fiscalizar o que acontece em toda indústria. A CETESB tem muita força política mas não tem força de equipe suficiente para fiscalizar. É necessário o compromisso com o meio ambiente".

Quando questionados sobre qual o principal benefício e/ou maior mudança ocorrida na empresa após 19 meses da certificação, quase todos os entrevistados apresentaram respostas múltiplas. Isso se explica porque há um link entre uma resposta e outra, ou seja, para um resultado ser atingido, às vezes tem que ser através de outros.

O principal benefício apontado por 47,8\% dos entrevistados é a ampliação da conscientização com as questões ambientais (Figura 19). Como um deles expôs: "Conscientização dos empregados, que levam isso para fora da empresa, multiplicando o conhecimento. Exercício de cidadania”.

Pode-se observar, também, a opinião dos diretores sobre o assunto:

"Mudar para ter um certificado não significa nada. Mudar para ter um certificado e atingir a conscientização das pessoas é o melhor resultado. Na empresa, conseguimos alcançar o objetivo e houve uma mudança de cultura e aquisição de consciência. E somos constantemente cobrados para manter essas atitudes 'politicamente corretas'”.

"Considero a certificação uma premiação por um trabalho que envolveu toda a empresa e que teve resultados positivos. Conseguimos criar consciência ambiental nas pessoas e uma responsabilidade por isso. Acesso irrestrito às informações para todos". 
Porém, um dos entrevistados destacou a dificuldade em obter qualquer mudança dentro de uma "população", uma vez que a empresa tem cerca de 10.000 (dez mil) colaboradores. Considerando o nível de escolaridade e o nível social de grande parte desses funcionários, ele diz: "A barreira das pessoas contra mudanças está diminuindo nesse aspecto. Melhorou a conscientização das pessoas”.

Figura 19: Principais benefícios percebidos com a certificação, na opinião dos entrevistados.

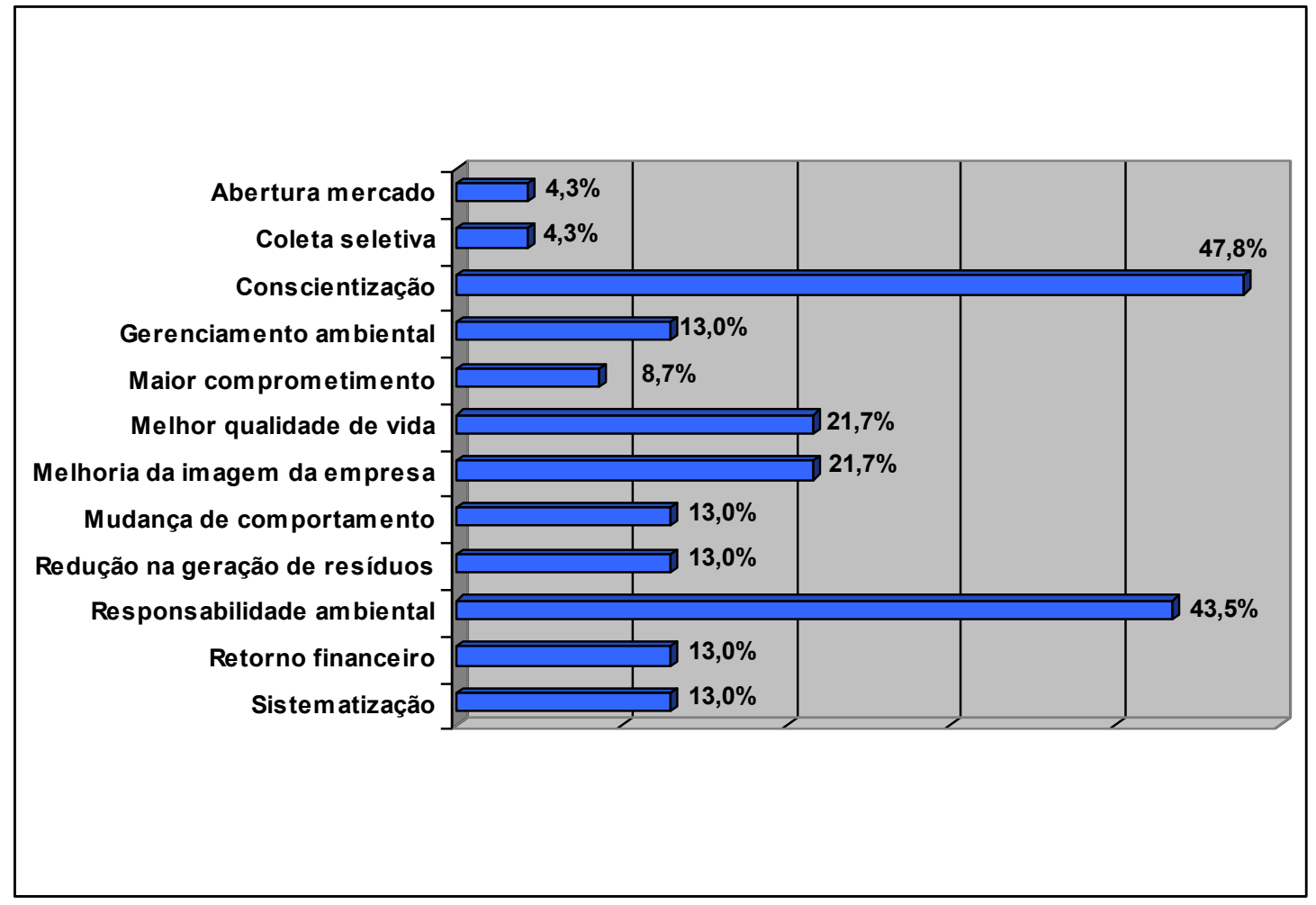

A responsabilidade ambiental dentro da empresa foi a principal mudança ocorrida na opinião de 43,5\% dos entrevistados. Esta responsabilidade foi surgindo, desde o momento em que a alta administração tomou a decisão de implantar um sistema de gerenciamento ambiental, passando por todo o processo de implementação até atingir a certificação. Este conceito está sendo cada vez mais incorporado ao dia-a-dia da empresa, como este colaborador nos explica:

"Não temos ainda na empresa uma cultura sobre essa questão ambiental. Então o que mais mudou foi a responsabilidade ambiental, principalmente dos funcionários do 'chão de fábrica' (é onde mais se nota). Eles agora exigem também da gente condições para trabalhar com os cuidados necessários". 
A melhoria da qualidade de vida e a melhoria da imagem da empresa foram os principais benefícios pós-certificação, segundo 21,7\% das respostas (Figura 19). Têm-se como exemplos:

"Melhorar a qualidade de vida dos funcionários, do entorno, e a melhoria na imagem da empresa”.

"Limpeza e organização da fábrica. Criação de um sistema de tratamento de efluentes. Também o fato de o funcionário levar essa consciência ambiental para a casa dele”.

"Maior comprometimento dos funcionários, que deixaram de ser leigos e passaram a se interessar. Também os beneficios para a imagem da empresa. O pessoal que trabalha com marketing e comunicação usa muito as informações da ISO 14001 para divulgação na empresa”.

Outros benefícios pós-certificação apontados pelos entrevistados foram: o gerenciamento de todos os aspectos e impactos ambientais significativos (13,0\%); a mudança de comportamento dos colaboradores $(13,0 \%)$; a redução na geração de resíduos (13,0\%); o retorno financeiro e economia de recursos financeiros $(13,0 \%)$; e a facilidade obtida com a sistematização de todo o processo produtivo e de todas as atividades da empresa $(13,0 \%)$. Convém destacar algumas dessas respostas, para ilustração:

"Maior garantia do SGA. O maior conhecimento dos focos importantes para analisar e resolver problemas, não mais receber penalidades ou advertências, o que ocorria por falta de comunicação. Ganhamos em agilidade na comunicação do processo e por um conhecimento mais detalhado de tudo que acontece no sistema de gestão ambiental da fábrica”.

"A certificação faz parte de um processo de melhoria contínua. Houve grandes mudanças nos processos da empresa, que geraram diferenças consideráveis, especialmente na geração de resíduos, reciclagem de óleo lubrificante, metas e 
planos de ação para redução de consumo de água e energia elétrica, etc.. A implantação do SGA propiciou essa mudança nos processos".

"A mudança comportamental dos colaboradores, que hoje vêem a questão ambiental com mais clareza e não a restringem ao simples fato de cuidar de plantas e animais".

"Conscientização das pessoas; controle e gerenciamento de riscos ambientais; economia de recursos financeiros; melhoria da imagem da empresa”.

"Esse sistema possibilita a sistematização das várias atividades da empresa e as pessoas passam a ficar mais interessadas na questão ambiental. Importância dessa conscientização não só no local de trabalho, mas saber que o cuidado com o meio ambiente possibilita uma melhor qualidade de vida de forma mais ampla".

Os que apontaram como maior mudança a certeza de que todos estão mais comprometidos com a questão ambiental dentro da empresa $(8,7 \%)$, justificam dessa maneira:

"Comprometimento maior das pessoas. Fazer sabendo o porquê e não fazer por fazer".

"Cuidados nas ações emergenciais (por exemplo, elevador com problema foi isolado). Mentalidade das pessoas em voltar ao produto para resolver problemas do meio ambiente".

E, por fim, a coleta seletiva de lixo e a abertura de mercado decorrente da ISO foram as maiores mudanças ocorridas na empresa, de acordo com 4,3\% das respostas, cada uma delas (Figura 19). Como, por exemplo:

"Coleta seletiva de lixo. Mudou o padrão de produção que, no futuro, terá retorno positivo no que diz respeito aos gastos feitos com as mudanças”. 
"A ISO está abrindo portas no mercado para a empresa. Também a melhora de qualidade do meio ambiente, na qualidade de vida das pessoas e de suas comunidades. O que não era adequadamente gerenciado, hoje é”.

Cumpre destacar a opinião de um dos entrevistados, que explicou a dificuldade por ele encontrada antes da sistematização de todo o processo e a importância de existir uma conscientização ambiental em toda a alta administração da empresa aliada a um comprometimento geral. Segue a resposta:

"Conscientização do corpo diretivo de que estamos de acordo com a legislação ambiental. Como técnico, sempre houve uma dificuldade para mostrar o que era ou não era correto e agora existem procedimentos a seguir, então temos o comprometimento de todos. A partir do momento que a empresa se dispõe a implantar a ISO 14001, se torna mais fácil porque já se tem o conhecimento de que será necessário investir e já houve aprovação dos diretores. Conseqüentemente, a diretoria passa a conhecer mais o assunto e se interessa pelo seu total cumprimento porque a multa por alguma não-conformidade é alta".

De acordo com a ISO 14001, a empresa deve identificar as atividades associadas aos aspectos ambientais significativos e assegurar que tais atividades sejam executadas sempre de acordo com sua política ambiental. Para isso, a organização deve estabelecer procedimentos documentados; estipular critérios operacionais nesses procedimentos; identificar os aspectos ambientais significativos de bens e serviços utilizados por ela e; por fim, comunicar aos seus fornecedores e prestadores de serviço toda a sua política, objetivos e metas (Item 4.4.6).

Por essa razão, todos os entrevistados foram questionados sobre as exigências e respectivo cumprimento da legislação ambiental imposta aos terceiros fornecedores e concessionários. Ficou esclarecido que existe um trabalho de acompanhamento da empresa, tanto com os fornecedores como com os concessionários, para controlar os impactos ambientais e a destinação final adequada dos resíduos gerados. 
Quanto aos fornecedores, 55,6\% dos entrevistados responderam que existe uma cobrança quanto ao cumprimento integral da legislação ambiental e isso é feito através de auditorias periódicas (Figura 20). Para os fornecedores que lidam com a destinação final de resíduos, é realizada uma auditoria bem rigorosa. Para os fornecedores de material produtivo, é feita uma auditoria de conformidade legal e cobra-se um plano de ação. Realizam-se, também, auditorias esporádicas de transporte para ter certeza que o caminhão que saiu da empresa foi para o lugar determinado, independentemente de comprovação via documentos. Um dos colaboradores colocou sua opinião sobre essa intervenção:

"Acho de extrema importância, pois desvio na conduta da atividade de terceiros pode gerar problemas para a imagem da empresa e também problemas no processo produtivo, como por exemplo interrupções na linha de produção por falta de peças ou de serviço decorrente da interdição de um terceiro".

Figura 20: Relação empresa - fornecedores, na opinião dos entrevistados.

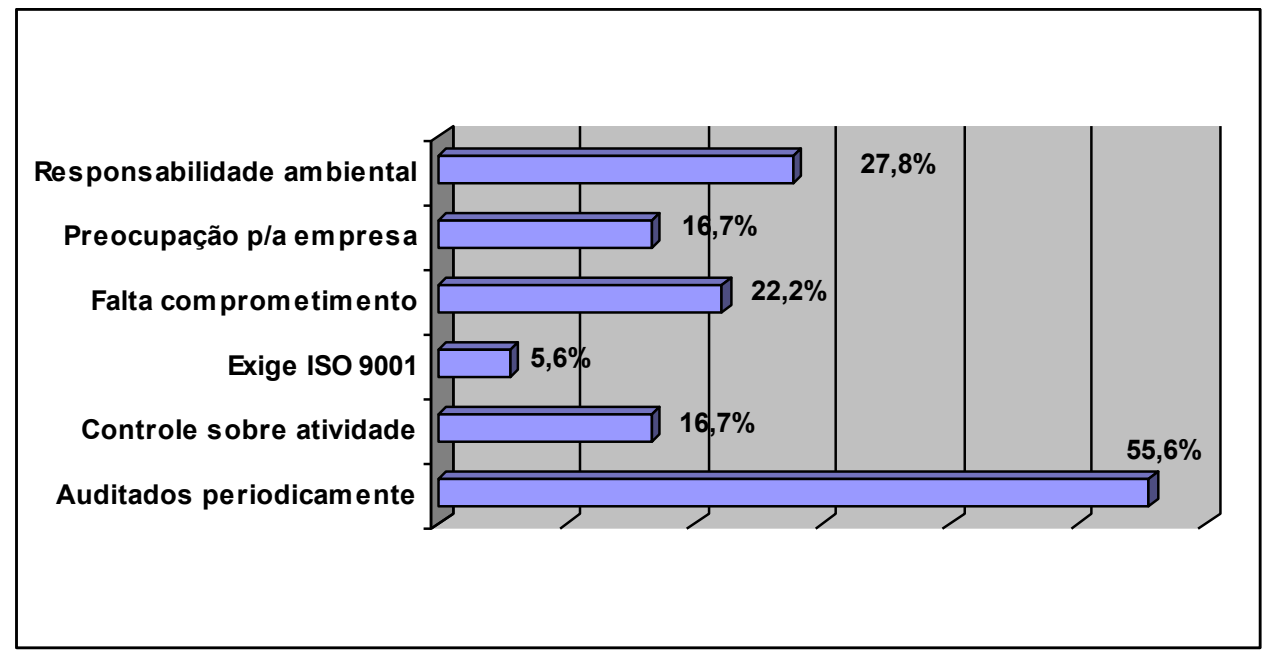

A responsabilidade ambiental foi citada por $27,8 \%$ dos entrevistados e $22,2 \%$ reclamaram que falta comprometimento e seriedade dos fornecedores quando se trata de questões ambientais, como se pode conferir nessas respostas:

"Qualquer fornecedor deve passar por uma auditoria para verificar se preenche os requisitos para ser fornecedor da empresa. É a co-responsabilidade. Essa auditoria é bem criteriosa. A maioria deles já tem a certificação ou está buscando”. 
"No começo, teve resistência por parte dos fornecedores pois eles alegavam que a CETESB não exigia aquilo deles. O empresário brasileiro não quer dispor de recursos para fazer o que a legislação pede. Precisa uma maior conscientização dos empresários brasileiros que não entendem a importância da preocupação com o meio ambiente. Os fornecedores que não se adequarem podem acabar fechando, pois não estarão de acordo com as exigências das empresas (Ford, Volks, etc.)".

Este tema é preocupação constante para a empresa (16,7\%), conforme segue: "Quanto aos fornecedores, existem algumas exigências. Os prestadores de serviço (internos) também devem ter o mesmo rastreamento de problemas ambientais que nossa empresa tem. Como somos os geradores iniciais, temos a preocupação de surgir um passivo ambiental".

Os outros $16,7 \%$ acreditam que é necessário haver um controle constante das atividades dos fornecedores, para evitar qualquer problema para a empresa (Figura 20) e os 5,6\% restantes, disseram que a empresa exige o certificado ISO 9001 dos fornecedores e agora está se preparando para exigir também a ISO 14001.

Importante frisar que, segundo os entrevistados, nem todos os fornecedores estão preparados para atender a essas exigências. A empresa faz avaliações e auditorias. Não é exigida a certificação, mas sim boas práticas ambientais. Se for encontrada alguma vulnerabilidade que possa prejudicar a imagem da empresa, este fornecedor é descadastrado.

Em relação aos concessionários, a posição da empresa difere um pouquinho, como explica este colaborador: "Quanto aos concessionários, como eles são independentes, não há como exigir deles. Apenas é feito um trabalho de conscientização. Isso gera mais investimento e mão-de-obra, então têm uma certa resistência. Falta ainda um trabalho mais forte com os concessionários". 
Figura 21: Relação empresa - concessionários, na opinião dos entrevistados.

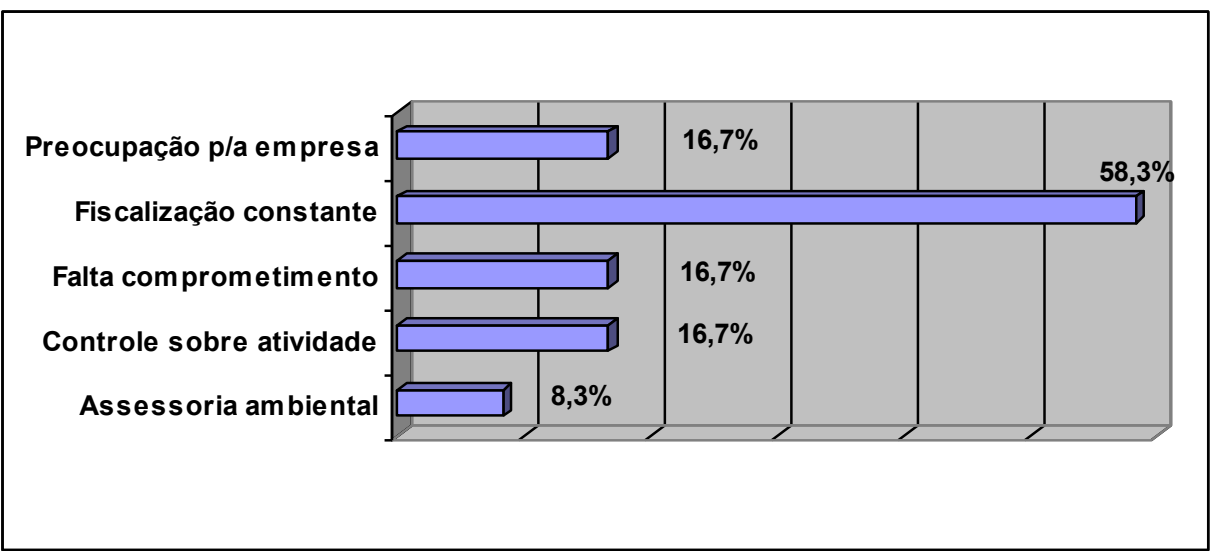

$\mathrm{Na}$ opinião de $58,3 \%$ dos entrevistados, existe uma fiscalização constante da empresa sobre as atividades dos concessionários. E, para viabilizar essas parcerias, a empresa oferece assessoria para os concessionários, possibilitando que toda a legislação ambiental seja cumprida (segundo 8,3\% dos entrevistados). Para melhor entendimento, seguem algumas respostas apresentadas:

"Como esses terceiros muitas vezes não têm profissionais na área, eles não têm consciência da necessidade dessa preocupação e não entendem o verdadeiro significado. Os concessionários não fazem parte da empresa, recebendo apenas uma concessão (de direito do uso da marca e venda dos produtos), sendo assim menos fiscalizados. Não são tão visados como a empresa. Justamente por isso que nós ficamos em cima. Mas a empresa dá incentivos e apoio para a proteção do meio ambiente”.

"Os concessionários, por representarem a marca, são mais exigidos nesse aspecto. O setor de vendas controla esse setor".

"Os fornecedores são auditados para verificar se estão conscientes e de acordo com as exigências da empresa. Os concessionários também são auditados. Se uma concessionária não consegue identificar os problemas ou solucioná-los, servimos como consultoria para ela e ajudamos a se enquadrar. Isso também acontece com os fornecedores. Quando é algo mais crítico, recomendamos contratar mão-de-obra especializada”. 
Este tema é preocupação constante para a empresa, com $16,7 \%$ das respostas (Figura 21), conforme segue:

“Com relação ao concessionário é diferente, pois não havia a concessão em si, mas a não-preocupação com o meio ambiente afeta a imagem dele. O dono da concessão não responde por qualquer crime ambiental e sim a marca que ele representa, então é uma preocupação para a empresa".

"Existem vários requisitos para cumprir porque existe a preocupação da empresa com qualquer problema ambiental ocorrido com seus fornecedores $e$ concessionários (ela também responderá). A empresa checa se a lei está sendo respeitada".

Referiram ser necessário haver um controle constante das atividades dos concessionários (16,7\%), para evitar possíveis complicações para a empresa (Figura 21). E os $16,7 \%$ restantes, alegaram que falta comprometimento por parte desses empresários e precisa ser realizado um forte trabalho de conscientização ambiental.

De todos os entrevistados, cinco não trabalhavam na empresa na época da implantação e, por essa razão, preferiram não responder essa questão.

Após terem sido abordados todos os aspectos e fases desde a implantação até a pós-certificação (passando pela implementação de um sistema e certificação), considerou-se que faltava a questão mais relevante para finalizar a entrevista. Daí a formulação dessa questão objetivando conseguir a opinião pessoal de cada um dos entrevistados sobre se a certificação valeu a pena, e por quê. 
Figura 22: Resultados atingidos com a certificação referidos pelos entrevistados.

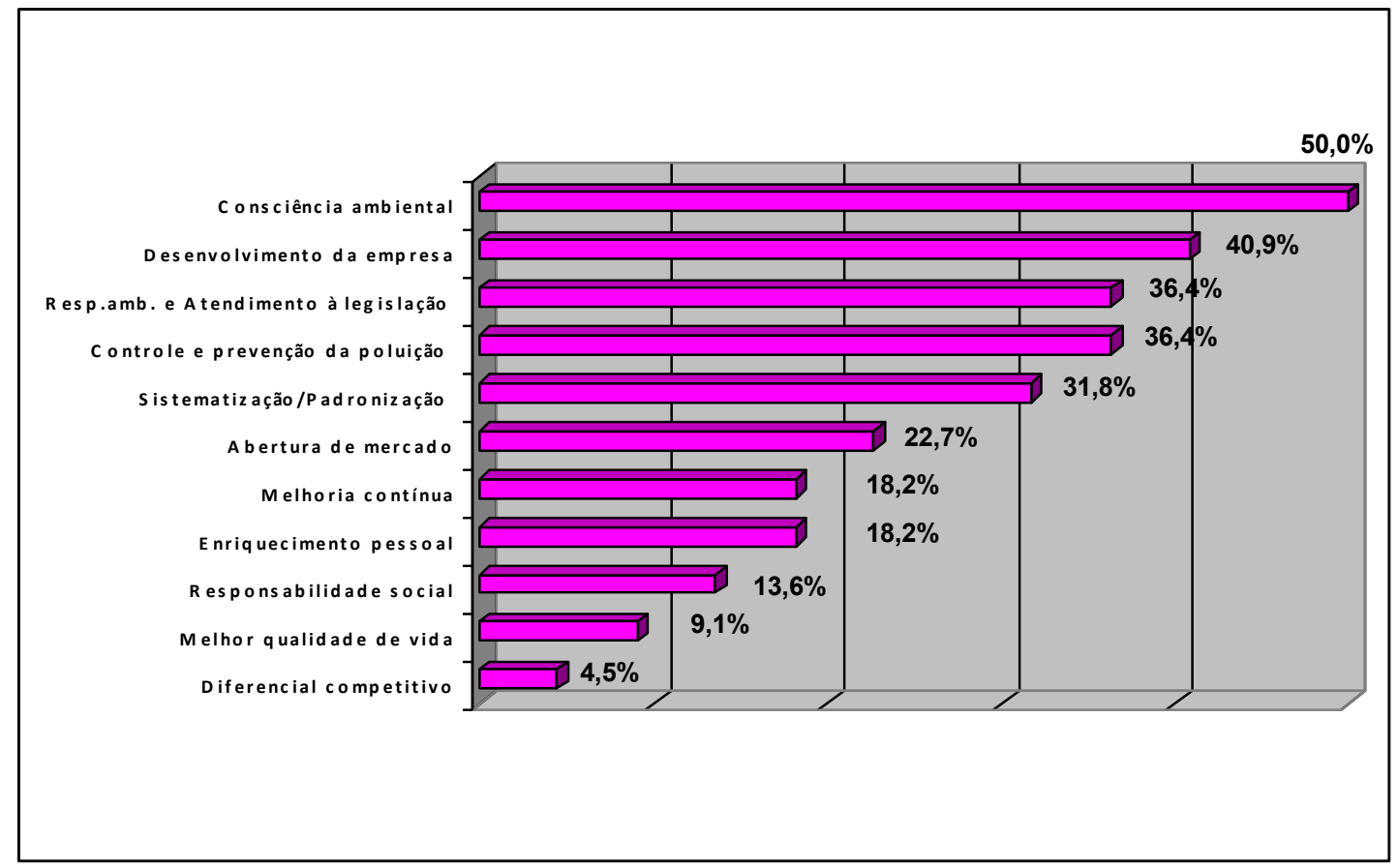

Todos os entrevistados responderam que a certificação valeu a pena e que todas as dificuldades encontradas durante esse processo foram superadas e 'deixadas para trás' quando eles olham para a empresa hoje. E cada declaração foi fundamentada e justificada com mais de uma razão, daí as porcentagens altas apresentadas na figura 22 .

A certificação trouxe ganho para a empresa, para os funcionários, para a sociedade em geral e para o meio ambiente. A conscientização ambiental adquirida durante todo esse processo foi a maior conquista, de acordo com 50,0\% das opiniões. Em segundo lugar, com 40,9\% das respostas, os entrevistados colocaram que a ISO 14001 proporcionou o desenvolvimento da empresa, conforme este exemplo:

"Acredito que um processo de gestão ambiental sistematizado e certificado contribui muito no desenvolvimento da empresa. Podemos ver com clareza a melhoria contínua dos processos, a prevenção à poluição e o comprometimento dos colaboradores com a questão ambiental". 
A certificação é uma forma de avaliar se a empresa está cumprindo a legislação; e determina os procedimentos a serem adotados para reparar qualquer risco ou dano ambiental, na opinião de $36,4 \%$ dos entrevistados (Figura 22). Um dos diretores expôs o seguinte:

"Sim. A certificação é uma forma de avaliar se a empresa está cumprindo a legislação; se o sistema de gestão funciona e o que está errado e precisa corrigir. Possibilidade de mensurar os possiveis impactos ambientais. Consciência ambiental coletiva (funcionários e suas famílias, fornecedores, prestadores de serviço). Reflete a imagem de uma empresa que respeita os princípios ambientais. $O$ objetivo foi alcançado. Melhoria contínua”.

"Sim, pelo crescimento da empresa e de seus funcionários. Houve um enriquecimento no que tange à responsabilidade para com o meio ambiente, independente de a legislação cobrar. Estamos mais responsáveis e levamos essa visão para dentro de casa".

Outros $36,4 \%$ dos entrevistados destacou que o maior resultado é o controle e prevenção da poluição, através da adoção de ações de caráter preventivo. Um exemplo: "Sem dúvida. A resposta do mercado é muito positiva. Gera tranqüilidade e segurança para a comunidade, especialmente quanto ao controle e prevenção da poluição. Tem um centro comunitário na Vila Paulicéia que ajudamos e eles sabem que fazemos gerenciamento das emissões. As outras empresas também nos procuram para fazer um 'benchmarking' e mostramos o sistema funcionando. O trabalho impressiona e expande em vários sentidos".

As facilidades trazidas com a sistematização dos processos e a padronização do comportamento dos indivíduos foram as razões apresentadas por 31,8\% dos entrevistados (Figura 22). Pode-se observar através desses exemplos:

"São estabelecidos padrões e assim fica mais fácil seguir uma sistemática (estabelecer um plano de ação, rodar um PDCA). A sistematização facilita a atuação concreta. Dá um diferencial competitivo para a empresa. Os colaboradores estão mais conscientes. Ampliou para o âmbito familiar. Houve redução de custos 
por causa da redução de resíduos. Possibilidade de ampliar exportação dos produtos".

"Sim, a certificação trouxe a sistematização e conseqüente organização da empresa e sua preocupação com a proteção ambiental (que deixou de ser esparsa)".

"Sim, o processo valeu a pena por causa dos resultados atingidos. A sistematização dos processos, essa visão mais holística do tema ambiental".

A uniformização das informações e a conscientização das pessoas proporcionam uma atualização constante, o que coloca a empresa como referência mundial em termos de produtividade, organização, eficiência e trabalho. Essas são as razões apresentadas pelos $22,7 \%$ dos entrevistados que apontaram a abertura de mercado e o estabelecimento de novos desafios como resultados mais relevantes obtidos com a certificação.

O enriquecimento pessoal só foi possível com a certificação, segundo 18,2\% das opiniões emitidas, pois o pessoal envolvido no processo ganhou experiência e conhecimentos (Figura 22). Esses passaram a questionar mais e assumir a responsabilidade por fatos que antes ignoravam a existência. Além disso, foram treinados e instruídos a disseminar a questão ambiental dentro de cada área da empresa. Algumas respostas ilustram bem esta afirmação:

"Sim, agregou valor para o colaborador. Pessoalmente, trouxe muito conhecimento. Também para a empresa, para o próprio meio ambiente, para a comunidade, trouxe muitas vantagens".

"Sim, pelo crescimento da empresa e de seus funcionários. Houve um enriquecimento no que tange à responsabilidade para com o meio ambiente, independente de a legislação cobrar. Estamos mais responsáveis e levamos essa visão para dentro de casa". 
O conceito de melhoria contínua, instituído pela ISO 14001, deve ser a meta de toda empresa que respeita os princípios ambientais, na opinião de $18,2 \%$ dos entrevistados. Um dos colaboradores expôs um argumento expressivo:

"Vale! Melhoria contínua. É uma norma que estabelece um sistema muito simples de gerenciamento, que parte de um princípio de PDCA (Plan, Do, Check, Act). Todos os sistemas de gerenciamento das normas são baseados no PDCA, como por exemplo o GQT, o OSHAS. Os modelos de sistema de gestão empresarial, que são 'MalcolmBaldrich' ou EFQM (European Foundation for Quality Management) ou PNQ (Prêmio Nacional da Qualidade), todos eles trazem um sistema baseado em PDCA e em melhoria contínua. Então percebemos uma integração do sistema de meio ambiente com o sistema de qualidade com o sistema de segurança e saúde ocupacional com o sistema de controle de indicadores, dentre outros. É uma tendência atual integrar todos esses sistemas em um só para demonstrar a composição do sistema de gestão da empresa. O ideal seria o SGA fazer parte do sistema de gestão empresarial”.

A responsabilidade social, tema tão presente e discutido atualmente, foi citada por $13,6 \%$ dos entrevistados e $9,1 \%$ das respostas são voltadas à melhoria da qualidade de vida (Figura 22).

Somente $4,5 \%$ dos entrevistados justificaram a alegação de que a certificação valeu a pena no fato de que um certificado ISO 14001 pode ser considerado um diferencial competitivo.

Interessante destacar uma das respostas apresentadas, porque expõe claramente a dificuldade que um funcionário bem instruído e que possui uma certa consciência ambiental pode vir a ter, trabalhando em um lugar que ainda não tenha investido em processos 'ambientalmente corretos' e assumido uma posição de empresa socialmente responsável. Este funcionário já trabalha na empresa a 17 (dezessete) anos e participou de toda a transição com muito entusiasmo, podendo fazer uma análise comparativa do "antes" e do "depois", conforme segue um trecho de sua entrevista: 
"Enquanto funcionário, pessoa e membro da comunidade, ganhamos muito. Sendo um caminho sem volta, fica mais fácil cobrar. Tendo consciência, somos muito menos questionados. Enquanto técnico, era necessário insistir muito com os diretores toda vez sobre as questões que nos preocupavam. Agora que já investiram no processo, melhoraram a imagem da empresa, agregaram valor ao negócio, e sabem que ainda será necessário investir, a coisa ficou bem mais fácil”.

Ao analisar este quadro (Figura 22), o interessante é que todas as respostas apresentadas para esta última questão reúnem, em seu conteúdo, um pouco de cada tema abordado em toda a pesquisa realizada. Alguns entrevistados limitaram-se a dizer que haviam mencionado alguma coisa desse assunto na pergunta 'tal', outros aproveitaram para colocar de forma mais extensa e detalhada o seu ponto de vista, inclusive, acrescentando informações relevantes ao objeto deste trabalho. Pode-se constatar isso com esses exemplos:

"Sim, por todos os motivos já citados. Principalmente devido ao menor risco de impactos ambientais, economia para a empresa, conformidade legal, melhoria da imagem da empresa. Pode-se exibir um documento válido de que nosso sistema funciona e de que somos ambientalmente corretos. Só o certificado não vale, o que interessa é ter o sistema funcionando. Temos o exemplo de algumas empresas que têm o certificado e são os alvos de notícias relacionadas aos danos ambientais por elas causados".

"Valeu, pois toda mudança que busca uma melhoria sempre vale a pena. Trouxe uma melhora na qualidade de vida e do meio ambiente. Os resultados são visíveis no que se refere à efetiva redução na geração de resíduos. Estas mudanças são notadas pelas pessoas, que se sentem como parte do processo".

Ao se perguntar se todos os companheiros de trabalho pensavam da mesma maneira, referindo-se a pergunta anterior, $100 \%$ dos entrevistados responderam que sim. Isso demonstra a não-necessidade de pergunta de confirmação. 


\subsection{Conhecimento dos Funcionários do "Chão de Fábrica"}

Foi realizada uma entrevista com os funcionários do "chão de fábrica", em horário de descanso e de almoço, para avaliar o conhecimento sobre a Norma ISO 14001. A escolha dos funcionários abordados foi ao acaso, totalizando 101 (cento e uma) pessoas, mas não são representativas da população total.

A pergunta elaborada foi a seguinte: "Você sabe o que é ISO 14.001?"

Figura 23: Respostas apresentadas pelos funcionários de "chão de fábrica".

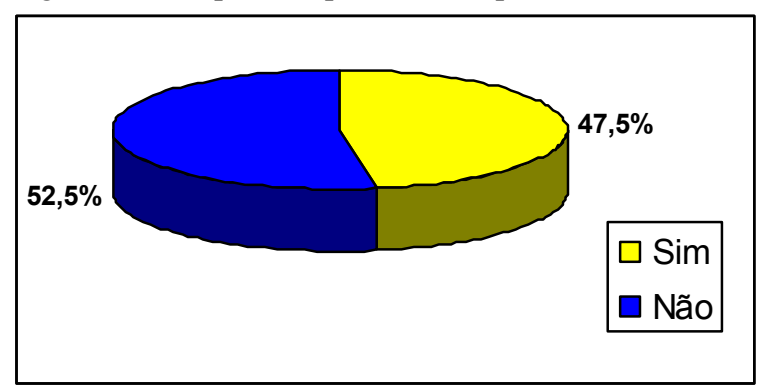

Dos 48 indivíduos $(47,5 \%)$ que disseram SIM, todos sabiam dizer que a ISO era relacionada com o meio ambiente (Figura 23). Destes, apenas 08 entrevistados foram além, dizendo que era uma norma que estabelecia procedimentos a serem seguidos para implantar um sistema de gestão ambiental.

Alguns responderam que era aquela "coisa" que dizia o que fazer com o pano sujo de óleo e onde descartar. Outros disseram ter ouvido falar, mas não se lembravam. Um dos funcionários disse estar com um papel sobre a ISO em cima da mesa mas não conseguia se lembrar para explicar. Finalmente, alguns responderam que tinha a ver com o "verdinho" (e apontava para uma árvore) ou que era aquele "negócio" chamado ecologia. 
De todos os que disseram NÃO (Figura 23), foram poucos aqueles que não tinham idéia do que se tratava. A maioria confundiu com a certificação ISO 9001 (Qualidade) e alguns confundiram com Segurança do trabalho, tema que estava sendo amplamente discutido naqueles meses (pois a empresa visa implementar o SGI). 


\section{DISCUSSÃO}




\section{DISCUSSÃO}

$\mathrm{O}$ acontecimento isolado mais freqüentemente apontado como significativo do começo da revolução ambiental foi a publicação, em 1962, de Primavera Silenciosa, de Rachel Carson. Considerado, em 1998, pela revista Time um dos 100 livros mais importantes da história, detalhou os efeitos adversos da má utilização dos pesticidas e inseticidas químicos sintéticos, gerou muita controvérsia e aumentou a consciência pública quanto às implicações da atividade humana sobre o meio ambiente e seus custos para a sociedade. Mostrou pela primeira vez que um relato meticulosamente pesquisado e lucidamente escrito sobre uma tecnologia imperfeita, era capaz de despertar as pessoas para que exigissem enfoque mais racional dos problemas do meio ambiente. Primavera Silenciosa tocou num ponto sensível de seus leitores, vendeu meio milhão de cópias encadernadas, permaneceu na lista dos mais vendidos do New York Times por 31 semanas, e incitou a criação de um grupo consultivo presidencial sobre pesticidas (BUREAU VERITAS 1998).

De lá pra cá, muita coisa mudou e percebe-se uma grande evolução no que diz respeito à elaboração de leis ambientais e seu efetivo cumprimento. A indústria passou a perceber que é responsabilidade de todos agir de modo a minimizar e prevenir impactos ambientais significativos, que possam causar algum dano ao meio ambiente. Inclusive, este conceito passou a ser incluído no planejamento estratégico da empresa. Em vários setores industriais, a introdução de ações de caráter preventivo em relação às questões ambientais tem demonstrado que a filosofia da prevenção à poluição não somente é uma ferramenta efetiva para um gerenciamento ambiental mais eficiente, como também traz uma série de benefícios econômicos (VILHENA \& POLITI 2000).

Apresentadas as informações básicas e os conceitos necessários para que seja possível ordenar as idéias e compreender a terminologia ambiental, às vezes especializada ou de introdução recente em nosso idioma, pode-se introduzir o tema Certificação em conformidade com a Norma ISO 14001, que é muito importante pois as normas da série ISO 14000 foram desenvolvidas por empresários e para 
empresários, visando a promoção da sustentabilidade e a facilidade de intercâmbio de mercadorias entre países.

Como o SGA é o conteúdo da Norma ISO 14001, foi realizado o estudo sobre os seus requisitos legais, implementação e operação do sistema, assim como sobre as técnicas utilizadas para avaliar os aspectos e impactos ambientais; administrar os riscos e encaminhar as ações corretivas.

A discussão dos resultados do presente trabalho não tem a pretensão de esgotar os assuntos aqui tratados nem se aprofundar em detalhes técnicos, que podem ser encontrados em literatura especializada, mas ressaltar os principais aspectos encontrados.

A discussão será conduzida em capítulos para facilitar a inter-relação com os resultados.

\subsection{População de Estudo}

A formação universitária dos entrevistados demonstra que a maioria (Figura 4) dos colaboradores da empresa opta pelo curso de engenharia, fator que está mudando com o tempo. Cada vez mais se faz necessária a interdisciplinaridade, quando se trata de questões do meio ambiente.

Como se percebe na figura 6, sete entrevistados estão trabalhando na empresa a um, dois, três ou quatro anos. Isso demonstra que grande parte dos colaboradores, que são os responsáveis pela questão ambiental em seus setores, entrou para os quadros da empresa durante ou após o processo de certificação. 


\subsection{Pesquisa com funcionários do "chão de fábrica"}

Nas entrevistas, quando questionados sobre a conscientização e percepção dos trabalhadores em relação à questão ambiental, todos os entrevistados diziam que se poderia sair andando pela fábrica e perguntar para qualquer um o que é ISO 14001 ou o que é meio ambiente que todos saberiam responder.

Resolveu-se testar. Sabe-se das dificuldades que a empresa enfrentou, pois se esse trabalho é difícil dentro de um domicílio com poucas pessoas, o que dizer de uma empresa com cerca de 10.000 funcionários?!? Abordar as pessoas de uma forma que não as intimidasse tornou-se um desafio. Observou-se que na hora da entrada e saída do almoço, todos os funcionários (horistas) estavam mais animados e dispostos para conversar.

O contato foi de forma suave e as reações deles as mais espontâneas possíveis e, às vezes, até engraçadas. O fator surpresa foi importante e a pergunta, quase em tom de brincadeira. Dos 120 indivíduos abordados ocasionalmente, somente 101 responderam, sendo a alegação para não resposta, que estavam com pressa ou nem falavam nada. As respostas não são representativas da população total, mas podem ser consideradas indicativas de uma realidade local.

Os entrevistados queriam ver o que se estava escrevendo e se interessavam em olhar o papel. Alguns queriam saber se tinha prêmio para quem respondesse e verificou-se que alguns sabiam o que era, mas não sabiam que palavra usar para responder.

A grande vantagem em usar a pesquisa qualitativa é a possibilidade desse contato mais estreito e ir além nas respostas e justificativas apresentadas, o que enriquece muito o trabalho.

Os resultados obtidos com a pesquisa (Figura 23) proporcionam um retorno gratificante ao processo de treinamento e conscientização desses funcionários, consideradas as condições precárias de educação e as diferenças sociais. Mas pode-se 
perceber que é necessário investir mais nesse aspecto, através de campanhas periódicas e palestras; e demonstrar o quê, como e por quê aquilo tem que ser feito.

\subsection{Questionário}

É interessante destacar os motivos que levaram a empresa a buscar a certificação ambiental em conformidade com a Norma ISO 14001, complementando com as opiniões de diretores e da alta administração de outras empresas. Ao se comparar as respostas, percebe-se a semelhança entre os motivos apresentados por todas as empresas certificadas.

Analisando-se as respostas, pode-se constatar que a decisão da certificação veio da direção da empresa. A matriz está localizada na Alemanha e todas as suas unidades no país de origem são certificadas e cumprem rigorosa política ambiental. Até por esse motivo, esta unidade de estudo já tinha comprometimento com as questões ambientais e com padrões mais rigorosos que os brasileiros. Um exemplo disso é a implantação da coleta seletiva em toda a empresa, no ano de 1995.

Diversas empresas justificam a implementação de um SGA em conformidade com a Norma ISO 14001 e conseqüente certificação no atendimento a diretrizes estabelecidas pela sua matriz. É uma tendência mundial das grandes organizações considerar a Qualidade e o Meio Ambiente como fatores críticos de sucesso e parte de um planejamento estratégico. E algumas vezes a solicitação da matriz pode ocorrer em função dos requisitos de diferentes clientes e/ou para remover barreiras comerciais. De acordo com Axel Schaefer, diretor executivo do Grupo Bayer do Brasil (Revista Meio Ambiente Industrial 2002), "existem diretrizes mundiais que determinam e orientam as ações das empresas do Grupo para o desenvolvimento sustentável”.

Em 1998, a Nokia, empresa com matriz na Finlândia, decidiu implementar um plano estratégico global para que todas as suas unidades fabris pudessem 
alcançar a certificação de acordo com o sistema de gestão ambiental do país em que estivessem localizadas. A empresa Siemens, de origem alemã, alinha suas ações em sintonia com o desenvolvimento sustentável, contribuindo com o país em que se insere na busca de uma melhor qualidade de vida para as pessoas, nos dias de hoje e no futuro. Com a empresa YKK do Brasil não é muito diferente e segundo o seu presidente mundial, Tadashiro Yoshida, a decisão de se implantar o SGA foi influenciada pela matriz corporativa do Japão, que determinou para as suas filiadas espalhadas pelo mundo a certificação em conformidade com a Norma ISO 14001 até dezembro de 2003. Ele diz:

“...o compromisso com o meio ambiente sempre foi uma de nossas prioridades, e reconhecemos, hoje em dia, que um dos deveres mais importantes que temos para com a humanidade é a preservação do meio ambiente, tão abundantemente dotado, $e$ que o transfiramos às próximas gerações em condições seguras”.

O que impulsionou a certificação, segundo 34,8\% dos entrevistados (Figura 8), foram as exigências de mercado, que passou a exigir produtos e serviços que levam em conta o aspecto ambiental e o controle sobre os impactos causados ao ambiente, adequando o cenário para melhor atender aos clientes, à comunidade, às demais partes interessadas e às futuras gerações.

Segundo Maria Tereza Vellano, vice-presidente da AES Eletropaulo (Revista Meio Ambiente Industrial 2002), o SGA, fundamentado na Norma ISO 14001, possibilita o reconhecimento público, através de certificação em conformidade com a norma ambiental, o que garante uma posição de liderança e destaque da empresa junto ao mercado competitivo. Ela diz:

“O SGA aprimora a relação entre as atividades da empresa e o meio ambiente em processo de melhoria contínua, estabelecendo um ciclo dinâmico".

A MWM, com 40,5\% de participação no mercado de produção e comercialização de motores diesel no Brasil, considera que a gestão ambiental é, atualmente, um diferencial das empresas e uma vantagem competitiva para aquelas, que, como ela, exportam, principalmente, para o mercado europeu. 
A imagem é uma das grandes preocupações das empresas, e a ISO 14001 proporciona uma melhoria dessa imagem, tornando-as mais atraentes para o mercado. Acompanhando o aumento da produção e do uso do automóvel, estão as questões relacionadas ao meio ambiente: consumo de combustível, a poluição do ar, o ruído, o fornecimento de peças, a correta destinação final dos resíduos por esses terceiros, entre outros (EPELBAUM \& AGUIAR 2002). Uma empresa automobilística tem um nível de poluição e utiliza materiais que podem agredir o meio ambiente e isso chama atenção. Como um dos entrevistados explicou:

"Somos produtores de caminhões. A poluição chama atenção contra a empresa. Emissão de fumaça dos veículos. Somos o líder de mercado e nos preocupamos com nossa imagem. A preocupação com o meio ambiente tem estado em evidência atualmente. Além disso, a empresa se preocupa com a sociedade e por essa razão se preocupa com o meio ambiente também”.

Segundo Mário Antônio Carneiro Cilento, vice-presidente executivo da Carbocloro S.A. Indústrias Químicas, empresa do Grupo Unipar (Revista Meio Ambiente Industrial 2002), a decisão de se implementar um SGA em conformidade com a ISO 14001 veio com o intuito de aprimorar suas diretrizes de gestão ambiental, e para reforçar ainda mais a imagem da empresa junto à comunidade, funcionários, entre outros: "o sucesso dessa conquista contribuiu para consolidar a imagem da empresa". Observou ainda, que mesmo já possuindo um SGA desde a década de 70, a certificação foi de fundamental importância para o aprimoramento deste sistema, pois os elementos e formalidades da norma acarretaram um maior envolvimento de todos os níveis hierárquicos da empresa.

Os principais motivos que levam uma empresa se decidir a implantar um sistema de gestão ambiental parecem ser consenso em todos os documentos consultados para essa discussão:

- Exigência por parte da matriz;

- Apelo de marketing para manter ou ampliar mercados, principalmente internacionais; 
- Solucionar pontos vulneráveis, com o cumprimento integral das leis ambientais;

- Redução dos custos e economia de recursos financeiros;

- Otimização dos processos e melhora na qualidade dos serviços;

- Responsabilidade social.

Infelizmente, para a maior parte das empresas, nem sempre essa decisão é baseada nos benefícios que podem ser obtidos com um sistema de gestão ambiental implementado e em funcionamento, como, por exemplo, a melhoria de seu sistema produtivo ou a redução de custos. Na prática, pode-se perceber que a demanda do SGA depende de exigências externas à empresa, especialmente advindas de clientes de grande porte ou de órgãos ambientais, ou ainda, de fatores externos, como incentivos de órgãos governamentais ou prêmios mais baixos de seguros (MOREIRA 2001).

Visando a certificação ISO 14001, a empresa adotou certos procedimentos, brevemente descritos a seguir: i. levantamento de como eram tratados os assuntos relacionados ao meio ambiente com a criação de um Grupo Multifuncional; ii. levantamento de aspectos e impactos ambientais, base para a definição da política; iii. cenários de risco e definição de prioridades; iv. criação de rede de comunicação interna, onde cada representante de área discutia o planejamento, as atividades de cada etapa e as dificuldades enfrentadas; v. treinamento dos funcionários.

Uma das principais ferramentas para as organizações que buscam a certificação ou que já estejam certificadas é a conscientização e o envolvimento de todos os seus colaboradores no processo. Se estes compreenderem que os procedimentos e instruções de trabalho pertencem a quem os aplica, certamente a iniciativa será bem-sucedida. Segundo Helena Carrascosa von Glehn, coordenadora do Projeto Pomar (que visa promover a recuperação ambiental e paisagística das margens do Rio Pinheiros em São Paulo), "O sistema de gestão deve estar a serviço das pessoas envolvidas, e não as pessoas a serviço dele. Este não deve representar um ônus a mais e, sim, uma ferramenta útil para o funcionamento da organização. 
Esta condição só se alcança a serviço de todos" (Revista Meio Ambiente Industrial 2002).

E, de acordo com Miguel Spohr, diretor-presidente da Tribel S.A., “o ponto principal de um processo de certificação é a sinergia entre representantes da alta administração e os demais colaboradores, de forma a transmitir a importância da obtenção do certificado e tornar sua manutenção uma conseqüência, e não uma causa do sistema de gestão da empresa” (Revista Meio Ambiente Industrial 2002).

O grau de conhecimento dos entrevistados foi avaliado pela descrição dos procedimentos adotados para a implantação e obtenção da ISO 14001. Conforme estabelecido pelo item 4.4.2 da norma, "a organização deve determinar que todo o pessoal cujas tarefas possam criar um impacto significativo sobre o meio ambiente receba treinamento apropriado". Os resultados obtidos mostraram o alto grau de conscientização da unidade, desde a alta administração até o nível operacional, refletindo o grau de efetividade da implantação e um SGA em conformidade com a Norma ISO 14001 (MOREIRA 2002).

A mudança de abordagem das questões ambientais por parte da alta administração provocada por uma aquisição de consciência ambiental, proporciona profundas modificações em suas prioridades estratégicas, sendo que algumas podem alterar as atitudes e os comportamentos dos colaboradores.

O Anexo 6 esquematiza os níveis de abordagem convencional, onde o meio ambiente é considerado um problema, e abordagem consciente, onde o meio ambiente passa a ser considerado uma oportunidade.

Os resultados sobre os procedimentos adotados para a implantação da certificação (Figura 9) refletem a realidade encontrada por toda empresa que busca uma mudança. Não é suficiente o presidente decidir, a diretoria apoiar, os gerentes e líderes operacionais adotarem o discurso de interesse pelo assunto. São indispensáveis o comprometimento e envolvimento de todos com a implantação do 
sistema, em cada uma de suas fases. Os treinamentos e as palestras de conscientização devem ser realizados periódica e continuamente, considerando-se os diferentes níveis sociais e educacionais dos colaboradores da empresa.

Como é difícil mudar o comportamento das pessoas! Um dos dispositivos mais importantes da norma diz que “....a organização deve estabelecer e manter procedimentos que façam com que seus empregados ou membros, em cada nível e função pertinente, estejam conscientes da importância de um SGA; de suas funções e responsabilidades; e das potenciais conseqüências da inobservância de procedimentos operacionais" (ABNT 1996). O que precisa ser feito para esse trabalho de conscientização dar certo? Como mostrar para as pessoas a importância da questão ambiental? Um sistema só poderá ser considerado implantado quando os indivíduos estiverem treinados e conscientizados de forma a realizar as atividades com responsabilidade ambiental.

Com relação aos resultados sobre a aceitação da certificação, os entrevistados ressaltaram a importância da continuidade nos treinamentos. Educar, segundo PELICIONI (1999), é prover situações ou experiências que estimulem a expressão potencial do homem e permitam a formação dessa consciência crítica e reflexiva. Implica em adesão voluntária e para que se efetive, é preciso que o sujeito social motivado incorpore os conhecimentos adquiridos, que a partir de então, serão parte de sua vida e transferidos para a prática.

O homem é um ser em transformação e ao mesmo tempo um agente transformador da sua realidade, sendo um grande desafio a mudança do comportamento do indivíduo e conseqüentemente do seu entorno. Fala-se muito em meio ambiente, mas no dia-a-dia, depara-se com cenas que confirmam que esse ainda é um conceito abstrato e distante.

As pessoas jogam lixo na rua, atiram objetos como lata de refrigerante pela janela do carro. Então, o que se pode dizer de um funcionário de nível operacional, formado em um ambiente que não valoriza o controle e prevenção da poluição? $\mathrm{Ou}$ do gerente de produção ou do diretor, para quem o importante é produzir e apresentar 
resultados? (COSIPA 1999) A única maneira de se garantir uma mudança,sem ser de maneira impositiva,é dando continuidade aos processos de treinamento, para que as pessoas incorporem atitudes e idéias.

Para o supervisor geral de Meio Ambiente da empresa multinacional Delphi Automotive Systems do Brasil Ltda., Luís Tubino, os motivos do sucesso da certificação é o envolvimento geral; a integração dos departamentos da companhia e o comprometimento de todos os funcionários, pois, de alguma maneira, há que se ter colaboração geral no processo (Revista Meio Ambiente Industrial 2002).

Segundo afirma Fatmi Nassif, gerente de Processos e Controle Ambiental da Atotech do Brasil Galvanotécnica Ltda., "a certificação é muito gratificante, uma vez que os funcionários e prestadores de serviços passam a aplicar seus conhecimentos, tanto na empresa, quanto em casa, transmitindo as informações aos familiares e à comunidade" (Revista Meio Ambiente Industrial 2002).

Ao estudar as respostas dos colaboradores que disseram ter havido uma difícil receptividade, as justificativas são a falta de conhecimento dos colaboradores; a velocidade com que todas as informações deveriam ser absorvidas e incorporadas ao dia-a-dia de todos; resistência da alta administração em se comprometer; e altos investimentos (Figura 10).

Após a certificação, percebe-se que as mudanças dentro da empresa foram muitas. Houve um aumento da responsabilidade e do comprometimento com o meio ambiente, principalmente com ações de caráter preventivo; gerenciamento dos riscos ambientais e redução na geração de resíduos.

A presença de painéis ilustrativos, colocados propositadamente nas áreas de lazer e descanso dos trabalhadores (Figura 12), foi uma medida adotada com bons resultados, pois despertou o interesse e é motivo de comentários entre os mesmos. 
A organização dos ambientes de trabalho melhorou muito, com a delimitação das áreas de ação (faixas pintadas no chão); instalação de trilhos que automatizam a distribuição de peças pelo percurso da linha de montagem; robotização dos processos; dentre outros. A limpeza dos locais de trabalho é realizada pelos próprios funcionários, e, em todas as instalações da empresa existem postos de coleta seletiva de lixo. Observou-se que esta coleta constituiu-se em prática totalmente incorporada pelos funcionários da empresa.

De acordo com as opiniões emitidas pelos entrevistados, ainda existem comportamentos que podem ser melhorados. Diversas ações permitem notar que os funcionários estão incorporando a questão ambiental não só no seu trabalho, como também no seu dia-a-dia. Exemplo disto é a reciclagem praticada, que serve de referência para outras empresas.

A adoção do programa japonês denominado $\mathbf{5 S}$ também acrescentou muito (filosofia japonesa de "housekeeping" = manter o processo organizado). Até os colaboradores cobram uns dos outros atitudes corretas, expandindo para o âmbito familiar e para suas comunidades o interesse pela questão.

A norma ISO 14001 foi redigida de forma a aplicar-se a todos os tipos e portes de organizações e para adequar-se a diferentes condições geográficas, culturais e sociais. No entanto, sabe-se que os investimentos necessários para a obtenção da ISO 14001 são muito altos, nem sempre acessíveis à maioria das empresas de pequeno porte.

A busca pela certificação ISO 14001 cresceu significativamente no Brasil, aumentando de 63 para 900 empresas certificadas em cinco anos (1997 a 2002), sendo que no mundo o aumento foi de \% no mesmo período (ISO 2003). Apesar de, no Brasil, o aumento ter sido de $157,14 \%$ de 2001 para 2002, muitos ainda a consideram apenas uma despesa ou um apelo de marketing. 
A implantação de um SGA ainda gera dúvidas sobre as vantagens de tal investimento. Algumas empresas concluem que fica muito mais caro não ter o sistema, face aos diversos riscos a que estão sujeitas, como acidente ambientais, multas, remediação de passivos, danos à imagem, barreiras comerciais, perda de competitividade, dentre outros (Figura 24). E com certeza a visibilidade de um certificado perante as exigências de certos mercados influenciam fortemente a decisão de muitas organizações.

Figura 24: Custo de um SGA.

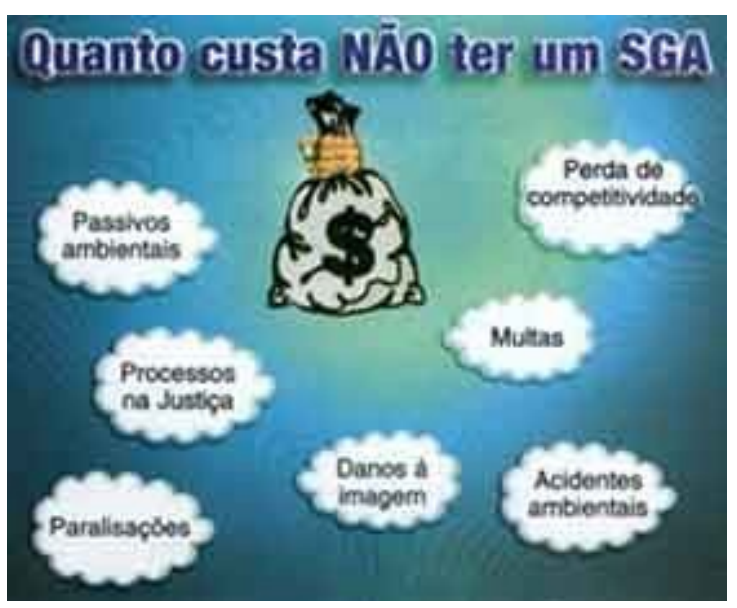

Fonte: MOREIRA 2001

Os comentários com relação à redução de custos pós-certificação devem ser motivo de discussão, pois investir em SGA não significa apenas agregar custos ao processo, mas sim colher receitas provenientes das mudanças. A empresa Bahia Sul Celulose obteve retorno de investimento após o primeiro ano de implantação. Do segundo ano em diante, foram significativas as reduções de custo em energia, matéria-prima, e água, entre outros (VILHENA \& POLITI 2000).

A maioria das empresas relata a certificação como condição para exportação dos produtos. Porém, os resultados apontaram para o fato de que a empresa em estudo encontrava-se capacitada para exportar, por atender totalmente às exigências dos países que são o destino dos produtos da empresa. 
Com relação às dificuldades encontradas no processo, destaca-se uma das respostas apresentadas: "Falta de comprometimento, tanto da chefia quanto dos funcionários. Mau planejamento da implantação que teve várias mudanças de rumo durante seu percurso. Problemas internos no grupo de implantação, como excesso de vaidade ou abuso de poder de alguns componentes, resultando em um desperdício de tempo e energia".

Esta situação relatada poderia ter sido minimizada com medidas, tais como: elaboração de um cronograma de implantação; destinar um bom tempo à realização de um diagnóstico o mais próximo possível da realidade, para evitar surpresas com altos investimentos; investir em treinamento e conscientização de todos os níveis da organização; e, assim, alcançar todos os seus objetivos, sempre se adequando a novos processos, equipamentos, a fim de buscar continuamente maior eficiência na proteção ambiental, visando o desenvolvimento sustentável.

A análise dos resultados sobre legislação indicou a fragilidade, não só do conhecimento, como do seu entendimento e aplicação, conforme explicitada na resposta: "O problema é importar as leis de outros lugares, que já aplicam a vinte anos, e querer que funcione aqui em um curto prazo (de 2 a 3 anos). Temos que nos encaixar nas 'regras do jogo'. A legislação gera trabalho e um custo adicional para a empresa, mas tem que ser cumprida”.

Segundo Frederico Marques Cabral, gerente de certificação da ABNT, as principais dificuldades encontradas pelas empresas durante a implementação da norma incluem a identificação da legislação; o acesso às tecnologias ambientais para adequação à legislação; investimentos necessários para esses ajustes; além de dificuldades em relacionar as atividades da empresa aos impactos ambientais e legislação aplicável (Revista Meio Ambiente Industrial 2003).

Por outro lado, um dos pontos fortes da atual legislação ambiental brasileira é o surgimento de leis específicas e mais restritivas. Antes, a legislação ambiental era uma barreira ao exercício das atividades produtivas de uma empresa. Hoje, passou a 
ser um instrumento que, com seu cumprimento integral, viabiliza e abre novos horizontes, e dá vida às relações da empresa com a sociedade pelo compromisso com a qualidade ambiental (VALLE 2002). A área de transporte, dentre os setores produtivos, é uma das que apresentam uma previsão de maior crescimento em termos de certificação ambiental, conforme referido por Roberto Oliveira Mendonça, técnico de Credenciamento e Auditor Líder de SGA, do INMETRO: "Os fatores que deverão alavancar o aumento do número de certificações são: a entrada em vigor de legislação mais restritiva, como, por exemplo, a proposta de Resolução CONAMA que estabelecerá os requisitos mínimos e o termo de referência para a realização de auditorias ambientais, objetivando avaliar os sistemas de gestão e controle ambiental nos portos organizados e instalações portuárias, plataformas e suas instalações de apoio e refinarias; o projeto de Lei do Senado que instituirá a Política Nacional de Resíduos Sólidos que, em suas diretrizes e normas também incentivará a certificação; a crescente conscientização e demanda do mercado, internacional e nacional, por produtos e serviços ecologicamente corretos; e a influência exercida pelas organizações já certificadas sobre seus fornecedores e clientes" (Revista Meio Ambiente Industrial 2002).

Com relação à exigência e respectivo cumprimento da legislação ambiental imposta aos fornecedores e concessionários, as auditorias ambientais podem contribuir de diversas formas. Como exemplo tem-se o caso das montadoras de automóveis. Os fornecedores de autopeças fabricam seus produtos com a logomarca das montadoras, e, no caso de ocorrer uma disposição final inadequada de peças e materiais fora de especificação, o primeiro prejuízo de imagem será da montadora. Por este motivo, aumenta o número de empresas que considera necessário executar auditorias ambientais em seus fornecedores. Em alguns casos, exige-se até a certificação ISO 14001 (PHILIPPI JR \& AGUIAR 2003).

A implantação do SGA em todas as suas fases, desde a implantação até a póscertificação, apresenta dificuldades como as anteriormente citadas, mas também resultados benéficos tais como a abertura de mercado; aumento no grau de conscientização ambiental dos funcionários, melhor preparação, por parte da 
empresa, frente a situações consideradas emergenciais e maior conhecimento sobre os aspectos ambientais de seus fornecedores; sistematização dos processos e responsabilidade social. Estes também foram alguns dos aspectos ressaltados por OLIVEIRA, 2000, em estudo no setor metal-mecânico. Embora o SGA não seja a solução para a resolução de todas as questões ambientais de uma organização, ele é uma ferramenta muito importante para o diagnóstico e gerenciamento destas questões.

Para que o SGA mantenha a melhoria contínua, a adequação, eficácia e seu desempenho, a alta administração da empresa deve realizar sua revisão periodicamente, uma vez que pode haver a necessidade de a empresa adotar uma política ambiental mais agressiva ou restritiva, decorrente de alterações na legislação; aumento de pressão do mercado; novas metodologias ou tecnologias; de novos requisitos das partes interessadas; entre outros. O processo de melhoria contínua exige uma busca incessante de novas oportunidades para o aperfeiçoamento do desempenho ambiental, e, quando bem aproveitadas, podem resultar em redução de custos operacionais (ALMEIDA 2000).

Ao finalizar a discussão, cumpre ressaltar que, atualmente, três grandes focos de atenção de qualquer empresa que busque sua sobrevivência em longo prazo são a qualidade do produto ou do serviço - ISO 9001; controle e gerenciamento ambiental - ISO 14001; e saúde ocupacional e segurança do trabalho - OSHAS 18001. A Norma OSHAS (Occupational Health and Safety Assessment) foi elaborada pelo British Standards Institution e emitida em 1999, sendo totalmente compatível com os modelos ISO 9001 e ISO 14001, possibilitando também a obtenção de certificado.

Os três sistemas citados podem resultar, futuramente, em um único sistema de gestão, denominado SGI - Sistema de Gestão Integrada, que busca otimizar os procedimentos, controles e recursos necessários ao gerenciamento de cada um desses temas*. Um SGI proporciona agilização nas auditorias; gestão sistematizada; menor burocracia; visão integrada; segurança ao atendimento dos requisitos legais; minimização dos fatores de risco; diferencial competitivo; fortalecimento da

* Disponível em <URL:http://www.fdg.org.br/iso14000/noticias/texto2.asp> . [2003 mai 28] 
imagem. A empresa objeto deste estudo está, atualmente, se preparando para implementar o sistema de gestão integrada em sua unidade, visando o alcance de todos esses benefícios. 
CONCLUSÕES 


\section{CONCLUSÕES}

Para determinar se as inovações alcançarão sucesso no mercado, o teste definitivo deve ser: "Será que elas realmente melhoram a qualidade de vida em geral?" Se o público consumidor cada vez mais fizer essa pergunta a si próprio e receber respostas satisfatórias nos produtos e serviços que encontra no mercado, a sociedade estará em trajetória mais sustentável.

A pergunta que eu me fazia era se uma certificação ISO 14001 (englobando desde a decisão da empresa em implantar um SGA em conformidade com a norma até a fase pós-certificação, que é o momento que a própria empresa deve fazer uma análise de como está funcionando seu sistema e se alguma ação corretiva se faz necessária) realmente melhorava a qualidade de vida em geral. Se refletia resultados positivos na vida das pessoas que lá trabalhavam e na vida da comunidade local e em seu próprio funcionamento.

E, mais do que isso, queria fazer um estudo de caso para poder conversar com todos os envolvidos em um processo de certificação, e, detectar as dificuldades encontradas nesse processo e meios para superá-las. E, aí sim, poder concluir que os benefícios obtidos são muito mais significativos do que qualquer conflito surgido.

O método empregado para obtenção dos resultados foi adequado. Com a aplicação do questionário e a permissão para gravar as entrevistas e, posteriormente, transcrevê-las, foi possível analisar todas as respostas com cuidado, o que agregou conhecimento ao estudo.

Ao avaliar a certificação ISO 14001, constatou-se a necessidade de dividí-la em quatro fases: implantação; implementação; certificação; e pós-certificação. $\mathrm{Na}$ fase da implantação, foram avaliados e discutidos todos os fatores que podem motivar uma empresa a buscar a certificação; verificou-se a necessidade da contratação de uma consultoria idônea para dar assessoria durante todo o processo; e fez-se um levantamento de todos os investimentos necessários. 
Na fase da implementação, avaliou-se a aceitação da alta administração e dos funcionários quanto aos procedimentos especificados na norma, onde foi possível notar a barreira que as pessoas tem contra mudanças e como é difícil vencer essa barreira; e destacaram-se as mudanças ocorridas dentro da empresa com o SGA em funcionamento.

$\mathrm{Na}$ fase da certificação, avaliou-se o grau de conhecimento e envolvimento dos entrevistados com relação a todo esse processo e também em relação à atual legislação ambiental brasileira.

Conclui-se, com os resultados obtidos, que a empresa em estudo, após 23 meses da certificação, identificou seus pontos fracos, e descobriu como e onde precisa melhorar; destacou seus maiores acertos, utilizando-os de forma a incentivar a continuidade do processo e estimular a adoção de novas práticas; incorporou definitivamente a variável ambiental na condução de seus negócios; convenceu a alta administração e a matriz a investirem mais em meio ambiente, porque o retorno é garantido e firma a empresa na trajetória do desenvolvimento sustentável; conscientizou-se que a manutenção do certificado passa a ser um desafio ainda maior.

O importante é a empresa ter muito claro que deve prosseguir buscando constantemente a melhoria de produtos e processos incentivando os parceiros, clientes e fornecedores a seguirem o mesmo caminho de excelência.

A ISO 14001 é o resultado da existência de harmonia entre todas as facetas que compõem o ser humano e o meio onde ele vive. Construir um meio ambiente equilibrado é resultado da ação de todos os habitantes do planeta, assim, fica aqui um convite a todos os interessados para o estudo do tema ambiental. 


\section{REFERÊNCIAS}

[ABNT] Associação Brasileira de Normas Técnicas. NBR ISO 14001: Sistemas de Gestão Ambiental - Diretrizes para uso e especificações. Rio de Janeiro; 1996.

[ABNT] Associação Brasileira de Normas Técnicas. NBR ISO 14012: Diretrizes para Auditoria Ambiental - Critérios de qualificação de auditores. Rio de Janeiro; 1996.

Almeida JR, Mello CS, Cavalcanti Y. Gestão ambiental: planejamento, avaliação, implantação, operação e verificação. Rio de Janeiro: Thex Ed.; 2000.

Bardin L. Análise de Conteúdo. Lisboa: Edições 70; 1995.

Benjamin AHV. Responsabilidade Civil pelo Dano Ambiental. Rev. Direito Ambiental. 1998; 9: 5-52.

Bianchi PNL. Meio ambiente: certificações ambientais e comércio internacional. Curitiba: Juruá; 2002.

Brasil. Constituição da República Federativa do Brasil. 2a ed. São Paulo: Revista dos Tribunais; 1997.

Bureau Veritas. Curso de treinamento de extensão em tecnologia de proteção ambiental. São Paulo; 1998.

Callenbach E., Capra F, Goldman L, Lutz R, Marburg S. Gerenciamento ecológico: guia do Instituto EImwood de auditoria ecológica e negócios sustentáveis. $9^{\mathrm{a}} \mathrm{ed}$. São Paulo: Cultrix; 1999. 
[CE] Comunidade Européia. Regulamento (CE) n. ${ }^{\circ}$ 761/2001 do Parlamento Europeu e do Conselho, de 19 de Março de 2001, que permite a participação voluntária de organizações num sistema comunitário de ecogestão e auditoria (EMAS). [documento online] Disponível em <URL:http://europa.eu.int> [2003 abr 26].

Coimbra JAA. O outro lado do meio ambiente: uma incursão humanista na questão ambiental. Campinas: Millenium, 2002.

Corrêa E. Coletânea da legislação ambiental. Compilada por Maude Nancy Graziani. Curitiba: Instituto de Terras, Cartografia e Florestas - ITCF; 1986.

Cosipa ISO 14001. Rev. Exame. 1999: 33 (17): p. 77-84.

Deus AS, Aguiar AO, Krzyzanowski MG, Frutuoso NG, Philippi TT e Groque TC. Gestão ambiental em empresas. São Paulo; 2001. [Monografia apresentada à disciplina HSA-5739 - Sistemas de Gestão Ambiental do curso de Pós-graduação em Saúde Pública]

Donaire D. Gestão ambiental na empresa. 2a ed. São Paulo: Atlas; 1999.

Epelbaum M, Aguiar A. ISO 14001 na cadeia automobilística. Rev. Banas Qualidade. 2002; XI (119): p. 50-52.

Gil AC. Métodos e técnicas de pesquisa social. 4ª ed. São Paulo: Atlas; 1994.

Kennedy RD. Have a laptop, will travel. In: Harrison L. Environmental, health and safety auditing handbook. $2^{\mathrm{a}}$ ed. New York: Mc Graw-Hill; 1994.

La Rovere EB, coordenador. Manual de auditoria ambiental. Rio de Janeiro: Qualitymark; 2000. 
Lemos HM. Administração estadual e o controle do meio ambiente. Instituto Brasileiro de Administração Municipal. Belo Horizonte; 1981.

Manetti C, Poveda ER, Soares RT e Philippi TT. Responsabilidade civil em face do passivo ambiental. São Paulo; 2001. [Monografia apresentada ao Curso de Especialização em Direito Ambiental da Faculdade de Saúde Pública da Universidade de São Paulo]

Milaré E. Direito do ambiente: doutrina - prática - jurisprudência - glossário. São Paulo: Editora Revista dos Tribunais; 2000.

Moller CBR. Gestão ambiental na indústria farmacêutica: riscos, benefícios e oportunidades. São Paulo; 1998. [Dissertação de Mestrado - Universidade Mackenzie]

Moreira MS. Estratégia e implantação de sistema de gestão ambiental modelo ISO 14000. Belo Horizonte: Editora de Desenvolvimento Gerencial, 2001.

Moura LAA. Qualidade e gestão ambiental: sugestões para implantação das normas ISO 14001 nas empresas. $3^{\mathrm{a}}$ ed. São Paulo: Editora Juarez de Oliveira; 2002.

Mukai T. Direito ambiental sistematizado. $3^{\mathrm{a}}$ ed. Rio de Janeiro: Editora Forense Universitária; 1998.

Oliveira CHS. Aspectos da implantação do sistema de gestão ambiental (NBR ISO 14001) no setor metal-mecânico: o caso Embraco S.A. Fpolis. Florianópolis; 2000. [Dissertação de Mestrado - Universidade Federal de Santa Catarina]

Pelicioni MCF. As inter-relações entre a educação, saúde e meio ambiente. Biológico. 1999: 61 (2). 
Philippi Jr A, Aguiar A. Auditoria ambiental. In: Philippi Jr A, Romero MA, Bruna GC. Curso de gestão ambiental. São Paulo: Manole, 2003. No prelo.

Philippi Jr A, Bruna GC. Política e gestão ambiental. In: Philippi Jr A, Romero MA, Bruna GC. Curso de gestão ambiental. São Paulo: Manole, 2003. No prelo.

Revista Meio Ambiente Industrial. São Paulo; 2002; 38 (37 - edição especial).

Revista Meio Ambiente Industrial. São Paulo; 2003; 43 (42 - edição especial).

Ribeiro JCJ. Modelo para avaliação de desempenho de política pública de meio ambiente: avaliando o caso do estado de Minas Gerais. Belo Horizonte; 2003. [Tese de Doutorado - Universidade Federal de Minas Gerais]

Rio de Janeiro (Estado). Decreto Estadual No 21.470A, de 05 de junho de 1995. [documento online] Disponível em <URL: http://www.lei.adv.br> [2002 out 15].

Rio de Janeiro (Estado). Lei Estadual 1.898, de 25 de novembro de 1991. [documento online] Disponível em <URL: http://www.lei.adv.br $>$ [2002 out 15].

Salles R. Auditoria ambiental e seus aspectos jurídicos. São Paulo: LTr; 2001.

Silva, MMP. Curso sobre normas ambientais ISO 14000. OAB/CE Comissão do Meio Ambiente. [documento online] Disponível em <URL:www.oabce.org.br/comissoes/> [2002 fev 17].

[SMA] Secretaria de Estado do Meio Ambiente. Legislação estadual: controle da poluição ambiental - estado de São Paulo. São Paulo: CETESB; 1991. (Série Documentos)

[SMA] Secretaria de Estado do Meio Ambiente. BRASIL'92: perfil ambiental e estratégias. São Paulo; 1992. 
[SMA] Secretaria de Estado do Meio Ambiente. ISO 14001: série entendendo o meio ambiente. São Paulo; 1997.

Soares GFS. Direito internacional do meio ambiente: emergência, obrigações e responsabilidades. São Paulo: Atlas, 2001.

Valle CE. Como se preparar para as normas ISO 14000: qualidade ambiental. São Paulo: Pioneira; 1995.

Valle CE. Qualidade ambiental: ISO 14000. $4^{\mathrm{a}}$ ed. São Paulo: Editora SENAC São Paulo; 2002.

Vilhena A, Politi E. Reduzindo, reutilizando, reciclando: a indústria ecoeficiente.

São Paulo: CEMPRE - Compromisso Empresarial para Reciclagem/SENAI; 2000. 
BIBLIOGRAFIA

CONSULTADA 


\section{BIBLIOGRAFIA CONSULTADA}

[ABNT] Associação Brasileira de Normas Técnicas. NBR ISO 14004: Sistemas de

Gestão Ambiental - Diretrizes gerais. Rio de Janeiro; 1996.

[ABNT] Associação Brasileira de Normas Técnicas. NBR ISO 14010: Diretrizes para Auditoria Ambiental - Princípios gerais de auditoria ambiental. Rio de Janeiro; 1998.

[ABNT] Associação Brasileira de Normas Técnicas. Interpretação NBR ISO 14001 (1996). Rio de Janeiro; 2001.

Andrade CF. Procurando o lucro com responsabilidade ecológica. Rev. Qualidade na Construção. 1998; II (12): p. 33-43.

Antunes PB. Direito ambiental. 4a ed. Rio de Janeiro: Lumen Juris; 2000.

A Onda Definitiva. Rev. Expressão. 1997; 7 (82): p. 24-30.

Benjamin AHV. O princípio poluidor-pagador e a reparação do dano ambiental. In: Dano ambiental: prevenção, reparação e repressão. São Paulo: Revista dos Tribunais; 1993. p. 226-236.

Benjamin AHV, Sicoli JCM, Andrade FAV. Legislação ambiental: manual prático da promotoria de justiça do meio ambiente. $2^{\text {a }}$ ed. São Paulo: IMESP; 1999.

Bogdan R, Biklen S. Investigação qualitativa em educação: uma introdução à teoria e aos métodos. Portugal: Porto Editora; 1994.

Bright C, Flavin C, Gardner G, MacDonald M, McGinn AP, Nierenberg D et al. Estado do mundo: a "impossível” revolução ambiental está acontecendo. Apresentação senadora Marina Silva. Salvador: Uma Ed.; 2003. 
Epelbaum M. ISO 14001: expectativas, resultados, riscos e oportunidades. [Apresentado ao VI Encontro Nacional sobre Gestão Empresarial e Meio Ambiente; promovido pela FEA/USP e EAESP/FGV; 2001; São Paulo].

[FIESP/CIESP]. Micro e pequenas empresas no estado de São Paulo e a legislação ambiental. São Paulo; 2001.

Fink DR, Alonso Jr. H, Dawalibi M. Aspectos jurídicos do licenciamento ambiental. São Paulo: Forense Universitária; 2000.

Fiorillo CAP, Rodrigues MA. Manual de direito ambiental e legislação aplicável. São Paulo: Max Limonad; 1997.

Freitas E. Philips: segunda unidade certificada na América Latina. Rev. Saneamento Ambiental. 1999; X (58): p. 44-46.

Furtado JS, Silva MLP. Meio ambiente: produção e tecnologias limpas. Bol. Fundação Vanzolini. 2000; IX (42): p. 6-8.

Gonçalves L. Certificação ISO 14001: novas certificações. Rev. Meio Ambiente Industrial. 1999; IV (19): p. 26-33.

Holliday $\mathrm{Jr}$ CO, Schmidheiny S, Watts $\mathrm{P}$. Cumprindo o prometido: casos de sucesso de desenvolvimento sustentável. Trad. de ACC Serra. Rio de Janeiro: Campus; 2002.

[ISO] International Standardization Organization. The ISO Survey shows continued growth of ISO 9000 and ISO 14001 certification. [online] Available from <URL:http:/www.iso.ch/iso/en/commcentre/pressreleases/2003/Ref864.html> [2003 aug 18]. 
Ludke M, Meda A. Pesquisa em educação: abordagens qualitativas. São Paulo: EPU; 1986.

Lyra MM. Dano Ambiental. Rev. Direito Ambiental. 1997; 8: 49-82.

Machado PAL. Auditoria Ambiental: Instrumento para o Desenvolvimento Sustentável. Rev. Direito Ambiental. 1995; n. 0.

Machado PAL. Direito ambiental brasileiro. $8^{\text {a }}$ ed. São Paulo: Malheiros Editores Ltda.; 2000.

Mello S. Meio ambiente como parte da qualidade. Rev. Saneamento Ambiental. 2000; XI (63): p. 50-52.

Milaré E. Tutela jurídico - civil do ambiente. Rev. Direito Ambiental. 1996; 0: 2672.

Moura LAA. Qualidade e gestão ambiental. $2^{\mathrm{a}}$ ed. São Paulo, Editora Juarez de Oliveira; 2000.

Padrão facilita o comércio. Rev. Questão. 2001; I (5): p. 24-28.

Pasqualotto A. Responsabilidade civil por dano ambiental, In: Dano ambiental: prevenção, reparação e repressão. São Paulo: Revista dos Tribunais; 1993. p. 445470 .

Pedro AFP. Aspectos ideológicos do ambiente. Rev. Cultura. 2001; 2 (4): p. 45.

Pinto WD, Almeida M. Resoluções do Conselho Nacional do Meio Ambiente CONAMA - 1984/1999. Brasília: Editora Ambiental; 1999. 
Philippi Jr A, Alves AC, Roméro MA, Bruna GC. Meio Ambiente, direito e cidadania. São Paulo: Signus Editora; 2002.

Philippi Jr A, Elias EO, coordenadores. A questão ambiental urbana: cidade de São Paulo. São Paulo [Cidade]: Secretaria do Verde e do Meio Ambiente; 1993.

Sanchez LE. Desengenharia: o passivo ambiental na desativação de empreendimentos industriais. São Paulo: Edusp; 2001.

Silva JA. Direito ambiental constitucional. $2^{\text {a }}$ ed. São Paulo: Malheiros Editores Ltda.; 1995.

Soares GFS. A proteção internacional do meio ambiente. Barueri: Manole; 2003.

[USEPA] United States Environmental Protection Agency. Environmental management systems. [serial online] Available from <URL:http://www.epa.gov/ems/index.htm> [2003 mar 17]. 